Prepared in cooperation with the San Antonio Water System

\title{
Water-Quality Observations of the San Antonio Segment of the Edwards Aquifer, Texas, With an Emphasis on Processes Influencing Nutrient and Pesticide Geochemistry and Factors Affecting Aquifer Vulnerability, 2010-16
}

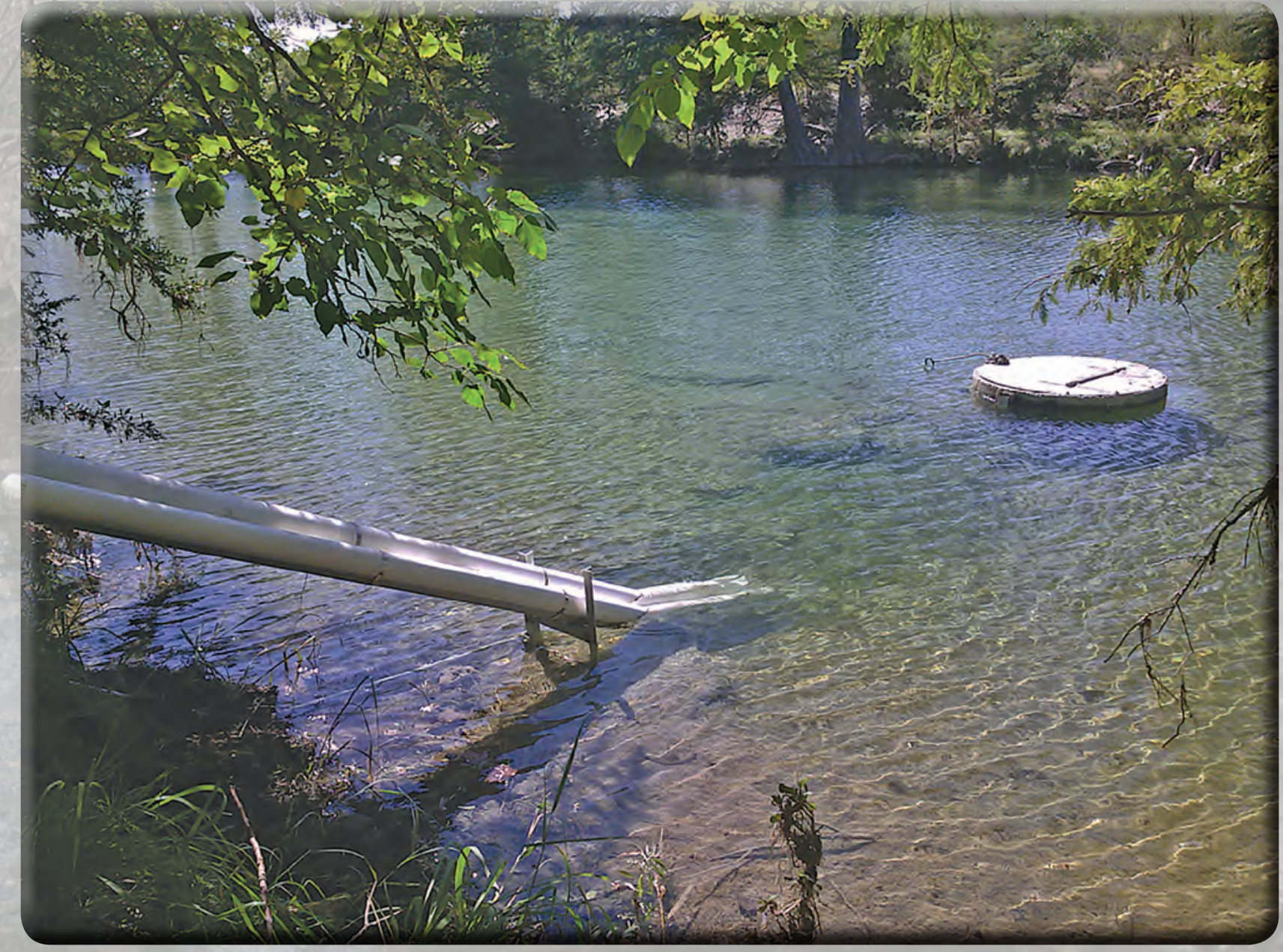

Scientific Investigations Report 2018-5060 
Front cover, Monitoring equipment at Frio River at Concan, Tex.

Back cover:

Top left, Pump hoist truck at Shavano Park at Fawn Drive.

Top right, Groundwater sampling equipment at AY-68-27-610 (Parkwood Park).

Middle, Comal 1 spring run.

Bottom, Nitrate sensor at the Frio River at Concan, Tex. 


\section{Water-Quality Observations of the San Antonio Segment of the Edwards Aquifer, Texas, With an Emphasis on Processes Influencing Nutrient and Pesticide Geochemistry and Factors Affecting Aquifer Vulnerability, 2010-16}

By Stephen P. Opsahl, MaryLynn Musgrove, Barbara J. Mahler, and Rebecca B. Lambert

Prepared in cooperation with the San Antonio Water System

Scientific Investigations Report 2018-5060 


\title{
U.S. Department of the Interior \\ RYAN K. ZINKE, Secretary
}

\author{
U.S. Geological Survey \\ James F. Reilly II, Director
}

U.S. Geological Survey, Reston, Virginia: 2018

For more information on the USGS - the Federal source for science about the Earth, its natural and living resources, natural hazards, and the environment-visit http://www.usgs.gov or call 1-888-ASK-USGS.

For an overview of USGS information products, including maps, imagery, and publications, visit http://www.usgs.gov/pubprod/.

Any use of trade, firm, or product names is for descriptive purposes only and does not imply endorsement by the U.S. Government.

Although this information product, for the most part, is in the public domain, it also may contain copyrighted materials as noted in the text. Permission to reproduce copyrighted items must be secured from the copyright owner.

Suggested citation:

Opsahl, S.P., Musgrove, M., Mahler, B.J., and Lambert, R.B., 2018, Water-quality observations of the San Antonio segment of the Edwards aquifer, Texas, with an emphasis on processes influencing nutrient and pesticide geochemistry and factors affecting aquifer vulnerability, 2010-16: U.S. Geological Survey Scientific Investigations Report 2018-5060, 67 p., https://doi.org/10.3133/sir20185060.

ISSN 2328-031X (print)

ISSN 2328-0328 (online) 


\section{Contents}

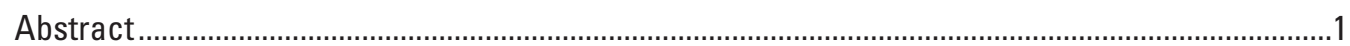

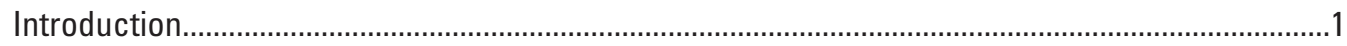

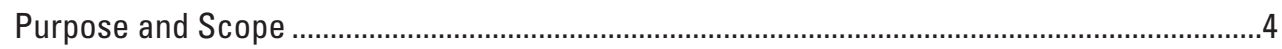

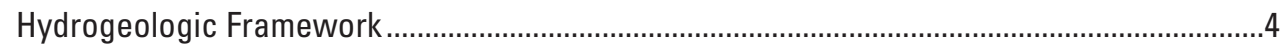

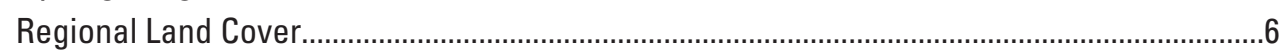

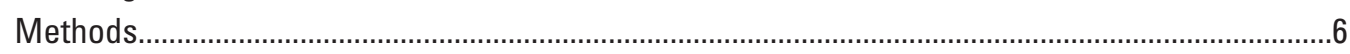

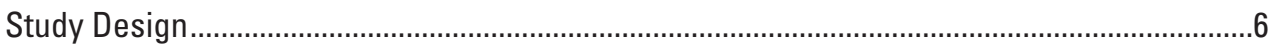

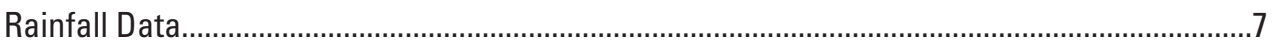

Streamflow Measurements ...........................................................................................

Continuous Water-Level Altitude Measurements ..................................................................

Continuous Water-Quality Monitoring..................................................................................

Discrete Water-Quality Sample Collection..............................................................................

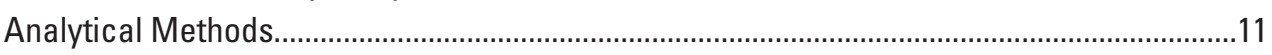

Quality Assurance for Water Samples .............................................................................13

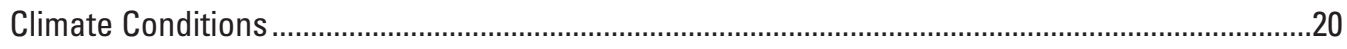

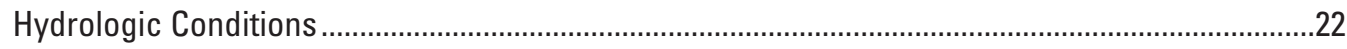

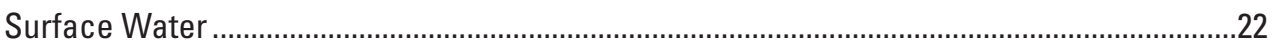

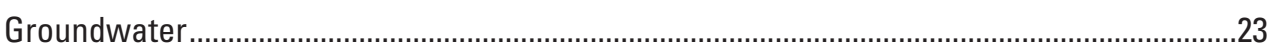

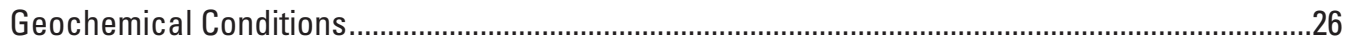

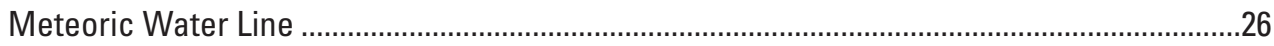

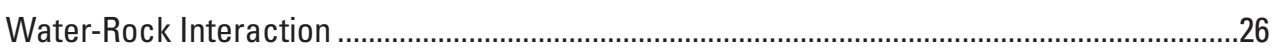

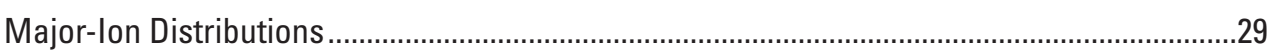

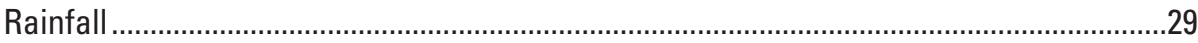

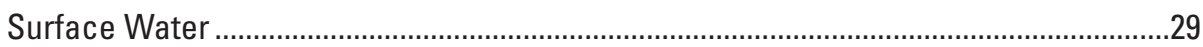

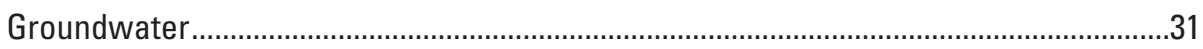

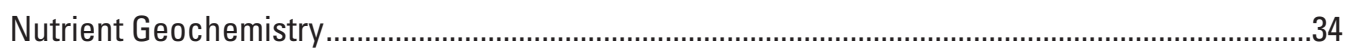

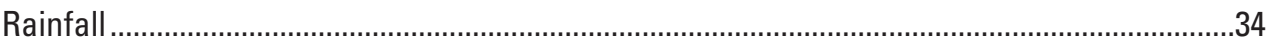

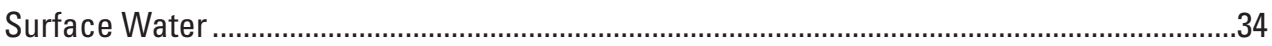

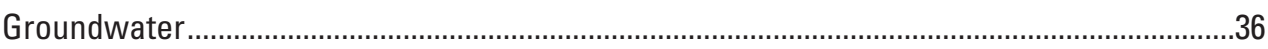

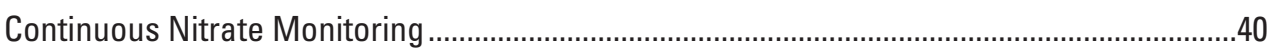

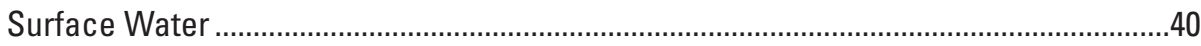

Unconfined Rural Groundwater ......................................................................................

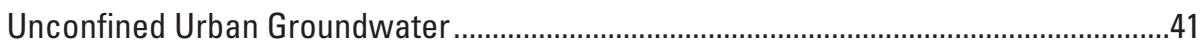

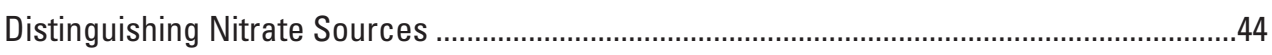

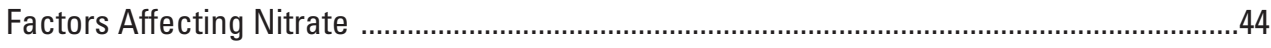

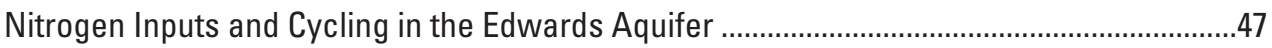

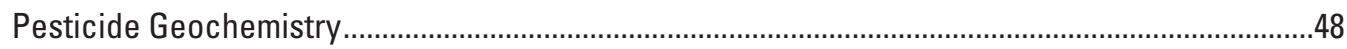

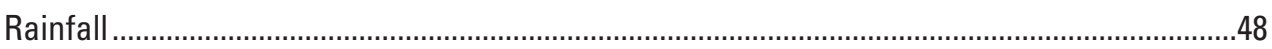

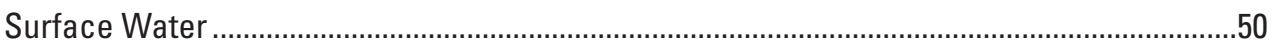

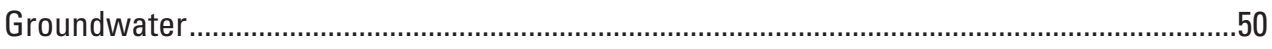

Factors Affecting Pesticides........................................................................................

Pesticide Inputs and Cycling in the Edwards Aquifer .......................................................57 


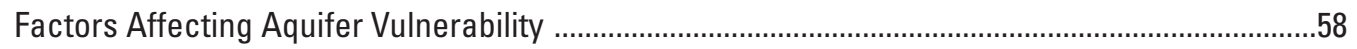

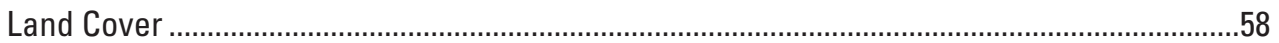

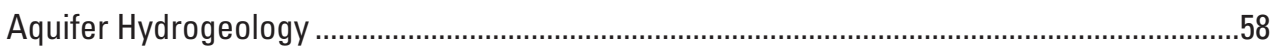

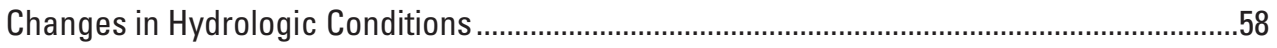

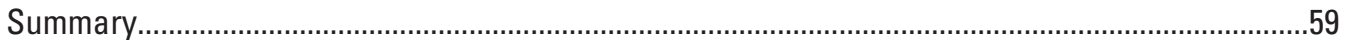

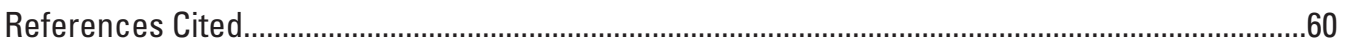

\section{Figures}

1. Map showing hydrogeologic setting and site locations in the San Antonio segment of the Edwards aquifer, south-central Texas

2. Diagram showing north-northwest-to-south-southeast section of hydrogeologic framework and generalized groundwater flow directions, Edwards Plateau to Gulf Coastal Plain, San Antonio region, Texas.

3. Graphs showing time series (July 2013-December 2016) of Palmer Drought Severity Index for the Texas Edwards Plateau; spring discharge for Comal Springs and water-level altitude for J-17 well; and daily rainfall recorded at Rainfall data 3

4. Graph showing daily median discharge, specific conductance, and sample-collection dates at Frio River (station 0819500), San Antonio segment of the Edwards aquifer, south-central Texas, July 2013-December 2016.

5. Graphs showing water-level altitude, specific conductance, and sample-collection times at Seco Well, Parkwood well, Shavano well, Zarzamora well, Turtle well, Mission well, and Comal 1 spring in the San Antonio segment of the Edwards aquifer, south-central Texas, July 2013-December 2016

6. Graphs showing relation between deuterium and oxygen isotopes measured in rainfall samples, surface-water samples, and groundwater samples collected from the San Antonio segment of the Edwards aquifer, south-central Texas, 2013-16

7. Graphs showing relation between strontium-87/strontium-86 isotopic ratio and magnesium to calcium molar ratio and time series of strontium-87/strontium-86 isotopic ratio measured in groundwater samples collected from the San Antonio segment of the Edwards aquifer, south-central Texas, 2013-16.

8. Graphs showing concentrations of calcium, magnesium, sodium, bicarbonate, chloride, sulfate, and strontium measured in groundwater samples and Comal 1 spring samples collected from the San Antonio segment of the Edwards aquifer, south-central Texas, July 2013-December 2016.

9. Graphs showing concentrations of nitrate-nitrogen and orthophosphate-phosphorous measured in water samples collected from groundwater wells and Comal 1 spring, San Antonio segment of the Edwards aquifer, south-central Texas, July 2013-December 2016

10. Graph showing daily median discharge and daily median nitrate-nitrogen concentration at Frio River (station 0819500), San Antonio segment of the Edwards aquifer, south-central Texas, September 2015-December 2016. 
11. Graph showing instantaneous discharge, nitrate-nitrogen concentration, and specific conductance for a single stormwater-runoff event at Frio River (station 0819500), San Antonio segment of the Edwards aquifer, south-central Texas, September 20, 2016-0ctober 20, 2016

12. Graphs showing rainfall, daily median water-level altitude, and daily median nitrate-nitrogen for Seco well, July 2014-December 2016, and Parkwood well, September 2014-December 2016, San Antonio segment of the Edwards aquifer, south-central Texas

13. Graphs showing stable nitrogen and oxygen isotopes of nitrate (delta nitrogen-15 of nitrate and delta oxygen-18 of nitrate) measured in water samples collected from rainfall, surface-water, and groundwater sampling sites in the San Antonio segment of the Edwards aquifer, south-central Texas, 2011-16.

14. Graph showing stable nitrogen isotopes of nitrate (delta nitrogen-15 of nitrate) values versus nitrate-nitrogen concentration measured in groundwater water samples collected from sampling sites in the San Antonio segment of the Edwards aquifer, south-central Texas, 2013-16.

15. Graphs showing concentrations of ammonia-nitrogen and dissolved organic nitrogen measured in water samples collected from sampling sites in the San Antonio segment of the Edwards aquifer, south-central Texas, 2010-16.

16. Graph showing the sum of dissolved organic nitrogen and ammonia-nitrogen concentration versus nitrate-nitrogen concentration measured in water samples collected from sampling sites in the San Antonio segment of the Edwards aquifer, south-central Texas, 2010-16.

17. Graph showing concentrations of the herbicide metolachlor measured in surface-water and rainfall samples collected from sites in the San Antonio segment of the Edwards aquifer, south-central Texas, 2012-16.

18. Graph showing a comparison of the maximum concentrations of the five pesticides that were measured in both rainfall and surface-water samples collected from sites in the San Antonio segment of the Edwards aquifer, south-central Texas, 2012-16.

19. Graph showing daily median water-level altitude and concentrations of the atrazine degradate deethylatrazine (DEA) measured in water samples from Seco well in the San Antonio segment of the Edwards aquifer, south-central Texas, 2013-16.

20. Graphs showing daily median water-level altitude and concentrations of deethylatrazine (DEA), atrazine, and simazine measured in water samples from urban wells including Parkwood well and Zarzamora well in the San Antonio segment of the Edwards aquifer, south-central Texas, 2013-16.

21. Graph showing daily mean discharge at Comal Springs and concentrations of deethylatrazine (DEA), atrazine, simazine, and prometon measured in water samples collected from Comal 1 spring in the San Antonio segment of the Edwards aquifer, south-central Texas, 2013-16.

22. Graph showing daily median water-level altitude at Parkwood well and pesticide concentrations measured in groundwater samples collected from urban wells (Parkwood and Zarzamora wells) for atrazine and simazine in the San Antonio segment of the Edwards aquifer, south-centra Texas, 2013-16. 


\section{Tables}

1. Sites where hydrologic data were obtained and water-quality samples were collected in the San Antonio segment of the Edwards aquifer, south-central Texas, 2010-16.

2. Measured constituents, laboratory reporting levels, units, method references, and analyzing laboratories for water-quality samples collected from sites in the San Antonio segment of the Edwards aquifer, south-central Texas, 2010-16

3. Summary of quality-assurance data for selected compounds detected in equipment blank and field blank water-quality samples collected from sites in the San Antonio segment of the Edwards aquifer, south-central Texas, 2013-16

4. Summary of quality-assurance data of paired environmental and split replicate water-quality samples and associated relative percent difference calculations for water-quality sample pairs collected from surface-water, spring, and groundwater sites in the San Antonio segment of the Edwards aquifer, south-central Texas, 2013-16

5. Summary of selected major ions measured in rainfall samples collected from Frio River and Urban rainfall 1, 2, and 3, San Antonio segment of the Edwards aquifer, south-central Texas, 2012-16.

6. Summary of selected major ions measured in water samples collected from Frio River, Seco Creek, Culebra Creek, and Helotes Creek, San Antonio segment of the Edwards aquifer, south-central Texas, 2010-16.

7. Summary of selected nutrients and stable nitrogen and oxygen isotopes of nitrate (delta nitrogen-15 in nitrate and delta oxygen-18 in nitrate) measured in rainfall samples collected from Frio River (representative of rural land cover) and Urban rainfall 1, 2, and 3, San Antonio segment of the Edwards aquifer, south-central Texas, 2012-16

8. Summary of selected nutrients and stable nitrogen and oxygen isotopes of nitrate (delta nitrogen-15 in nitrate and delta oxygen-18 in nitrate) measured in surface-water samples collected from Frio River, Seco Creek, Culebra Creek, and Helotes Creek, San Antonio segment of the Edwards aquifer, south-central Texas, 2010-16.

9. Summary of selected nutrients and stable nitrogen and oxygen isotopes of nitrate (delta nitrogen-15 in nitrate and delta oxygen-18 in nitrate) measured in samples collected from groundwater wells and Comal 1 spring, San Antonio segment of the Edwards aquifer, south-central Texas, 2013-16..

10. Summary of pesticide concentrations measured in rainfall samples collected from Frio River and Urban rainfall 1, 2, and 3 in the San Antonio segment of the Edwards aquifer, south-central Texas, 2014-16.

11. Summary of pesticide detections in rainfall, surface-water, and groundwater samples collected from sites in the San Antonio segment of the Edwards aquifer, south-central Texas, 2012-16 


\section{Conversion Factors}

U.S. customary units to International System of Units

\begin{tabular}{lcl}
\hline \multicolumn{1}{c}{ Multiply } & By & \multicolumn{1}{c}{ To obtain } \\
\hline inch (in.) & Length & \\
inch (in.) & 2.54 & centimeter $(\mathrm{cm})$ \\
foot (ft) & 25.4 & millimeter $(\mathrm{mm})$ \\
mile (mi) & 0.3048 & meter $(\mathrm{m})$ \\
mile, nautical $(\mathrm{nmi})$ & 1.609 & kilometer $(\mathrm{km})$ \\
\hline & 1.852 & kilometer $(\mathrm{km})$ \\
\hline square mile $\left(\mathrm{mi}^{2}\right)$ & Area & \\
\hline & 2.590 & square kilometer $\left(\mathrm{km}^{2}\right)$ \\
\hline ounce, fluid $\left(\mathrm{fll}^{2} \mathrm{oz}\right)$ & Volume & liter $(\mathrm{L})$ \\
pint (pt) & 0.02957 & liter $(\mathrm{L})$ \\
quart $(\mathrm{qt})$ & 0.4732 & liter $(\mathrm{L})$ \\
gallon $(\mathrm{gal})$ & 0.9464 & liter $(\mathrm{L})$ \\
cubic inch $\left(\mathrm{in}^{3}\right)$ & 3.785 & liter $(\mathrm{L})$ \\
cubic foot $\left(\mathrm{ft}^{3}\right)$ & 0.01639 & cubic decimeter $\left(\mathrm{dm}^{3}\right)$ \\
cubic foot $\left(\mathrm{ft}^{3}\right)$ & 28.32 & cubic meter $\left(\mathrm{m}^{3}\right)$ \\
cubic yard $\left(\mathrm{yd}^{3}\right)$ & 0.02832 & cubic meter $\left(\mathrm{m}^{3}\right)$ \\
\hline & 0.7646 & \\
\hline cubic foot per second $\left(\mathrm{ft}^{3} / \mathrm{s}\right)$ & Flow rate & \\
\hline & 0.02832 & cubic meter per second $\left(\mathrm{m}^{3} / \mathrm{s}\right)$ \\
\hline
\end{tabular}

Temperature in degrees Celsius $\left({ }^{\circ} \mathrm{C}\right)$ may be converted to degrees Fahrenheit $\left({ }^{\circ} \mathrm{F}\right)$ as follows:

$$
{ }^{\circ} \mathrm{F}=\left(1.8 \times{ }^{\circ} \mathrm{C}\right)+32
$$

Temperature in degrees Fahrenheit $\left({ }^{\circ} \mathrm{F}\right)$ may be converted to degrees Celsius $\left({ }^{\circ} \mathrm{C}\right)$ as follows:

$$
{ }^{\circ} \mathrm{C}=\left({ }^{\circ} \mathrm{F}-32\right) / 1.8
$$

\section{Datum}

Vertical coordinate information is referenced to the National Geodetic Vertical Datum of 1929 (NGVD 29) or the North American Vertical Datum of 1988 (NAVD 88).

Horizontal coordinate information is referenced to the North American Datum of 1927 (NAD 27) or the North American Datum of 1983 (NAD 83).

Altitude, as used in this report, refers to distance above the vertical datum. 


\section{Supplemental Information}

Specific conductance is given in microsiemens per centimeter at 25 degrees Celsius $(\mu \mathrm{S} / \mathrm{cm}$ at $25^{\circ} \mathrm{C}$ ). Concentrations of chemical compounds in water are given in either milligrams per liter $(\mathrm{mg} / \mathrm{L})$ or micrograms per liter $(\mu \mathrm{g} / \mathrm{L})$. Milligrams per liter and micrograms per liter are units expressing the concentration of chemical compounds in solution as weight of solute (milligrams or micrograms) per unit volume (liter) of water.

\section{Isotope Unit Explanations}

Per mil $(\%)$ : A unit expressing the ratio of stable-isotope abundances of an element in a sample to those of a standard material. Per mil units are equivalent to parts per thousand. Stableisotope ratios are computed as follows (Kendall and McDonnell, 1998):

$$
\delta X=\left\{\left(R_{\text {sample }}-R_{\text {standard }}\right) / R_{\text {standard }}\right\} \times 1,000
$$

where

$$
\begin{aligned}
& \delta \quad \text { is the "delta" notation, } \\
& X \quad \text { is the heavier stable isotope, and } \\
& \mathrm{R} \text { is ratio of the heavier, less abundant isotope to the lighter, stable isotope in a } \\
& \text { sample or standard. }
\end{aligned}
$$

\begin{tabular}{|c|c|c|}
\hline Element & $\mathbf{R}$ & Standard identity and reference \\
\hline Hydrogen & Hydrogen-2/hydrogen-1 ( $\delta \mathrm{D})$ & $\begin{array}{l}\text { Vienna Standard Mean Ocean Water (VSMOW) } \\
\text { (Fritz and Fontes, 1980) }\end{array}$ \\
\hline Oxygen & Oxygen-18/oxygen-16 $\left(\delta^{18} \mathrm{O}\right)$ & $\begin{array}{l}\text { Vienna Standard Mean Ocean Water (VSMOW) } \\
\text { (Fritz and Fontes, 1980) }\end{array}$ \\
\hline Nitrogen-nitrate & $\begin{array}{l}\text { Nitrogen-15/nitrogen-14 }\left(\delta^{15} \mathrm{~N}-\right. \\
\left.\quad \mathrm{NO}_{3}\right)\end{array}$ & $\begin{array}{l}\text { USGS34 potassium nitrate }\left(\mathrm{KNO}_{3}\right) \text { and } \\
\text { USGS32 } \mathrm{KNO}_{3} \text { (Böhlke and others, 2003) }\end{array}$ \\
\hline Oxygen-nitrate & $\begin{array}{l}\text { Oxygen-18/oxygen-16 of nitrate } \\
\left(\delta^{18} \mathrm{O}-\mathrm{NO}_{3}\right)\end{array}$ & $\begin{array}{l}\text { USGS34 } \mathrm{KNO}_{3} \text { and USGS35 sodium nitrate } \\
\left(\mathrm{NaNO}_{3}\right)(\text { Böhlke and others, 2003) }\end{array}$ \\
\hline
\end{tabular}

The $\delta$ values for stable-isotope ratios discussed in this report are referenced to the following standard materials. 


\title{
Water-Quality Observations of the San Antonio Segment of the Edwards Aquifer, Texas, With an Emphasis on Processes Influencing Nutrient and Pesticide Geochemistry and Factors Affecting Aquifer Vulnerability, 2010-16
}

\author{
By Stephen P. Opsahl, MaryLynn Musgrove, Barbara J. Mahler, and Rebecca B. Lambert
}

\begin{abstract}
As questions regarding the influence of increasing urbanization on water quality in the Edwards aquifer are raised, a better understanding of the sources, fate, and transport of compounds of concern in the aquifer-in particular, nutrients and pesticides - is needed to improve water management decision-making capabilities. The U.S. Geological Survey, in cooperation with the San Antonio Water System, performed a study from 2010 to 2016 to better understand how water quality changes under a range of hydrologic conditions and in contrasting land-cover settings (rural and urban) in the Edwards aquifer. The study design included continuous hydrologic monitoring, continuous water-quality monitoring, and discrete sample collection for a detailed characterization of water quality at a network of sites throughout the aquifer system. The sites were selected to encompass a "source-to-sink" (that is, from aquifer recharge to aquifer discharge) approach. Network sites were selected to characterize rainfall, recharging surface water, and groundwater; groundwater sites included wells in the unconfined part of the aquifer (unconfined wells) and in the confined part of the aquifer (confined wells) and a major discharging spring. Storm-related samples-including rainfall samples, stormwater-runoff (surface-water) samples, and groundwater samples - were collected to characterize the aquifer response to recharge.

Elevated nitrate concentrations relative to national background values and the widespread detection of pesticides indicate that the Edwards aquifer is vulnerable to contamination and that vulnerability is affected by factors such as land cover, aquifer hydrogeology, and changes in hydrologic conditions. Greater vulnerability of groundwater in urban areas relative to rural areas was evident from results for urban groundwater sites, which generally had higher nitrate concentrations, elevated $\delta^{15} \mathrm{~N}$-nitrate values, a greater diversity of pesticides, and higher pesticide concentrations. The continuum of water quality from unconfined rural
\end{abstract}

groundwater sites (least affected by anthropogenic contamination) to unconfined urban groundwater sites (most affected by anthropogenic contamination) demonstrates enhanced vulnerability of urban versus rural land cover. Differences in contaminant occurrences and concentration among unconfined urban wells indicate that the urban parts of the aquifer are not uniformly vulnerable, but rather are affected by spatial differences in the sources of nutrients and pesticides. In urban areas, the shallow, unconfined groundwater sites showed greater temporal variability in both nutrient and pesticide concentrations, as well as a greater degree of contamination, than did deeper, confined groundwater sites. In comparison to that of the shallow, unconfined groundwater sites, the water quality of the deeper, confined groundwater sites was relatively invariant during this multiyear study. Although aquifer hydrogeology is an important factor related to aquifer vulnerability, land cover likely has a greater influence on pesticide contamination of groundwater. Temporal variability in hydrologic conditions for the Edwards aquifer is apparent in data for surface water as a source of groundwater recharge, water-level altitude in wells, spring discharge, and groundwater quality. This temporal variability affects recharge sources, recharge amounts, groundwater traveltimes, flow routing, water-rock interaction processes, dilution, mixing, and, in turn, water quality. Relations of land cover, aquifer hydrogeology, and changing hydrologic conditions to water quality are complex but provide insight into the vulnerability of Edwards aquifer groundwater-a vital drinking-water resource.

\section{Introduction}

The San Antonio segment of the Edwards aquifer (hereinafter referred to as the "Edwards aquifer"), located in south-central Texas (fig. 1), is a designated sole-source aquifer (U.S. Environmental Protection Agency, 2017a) and the primary water supply for more than 1.7 million people 


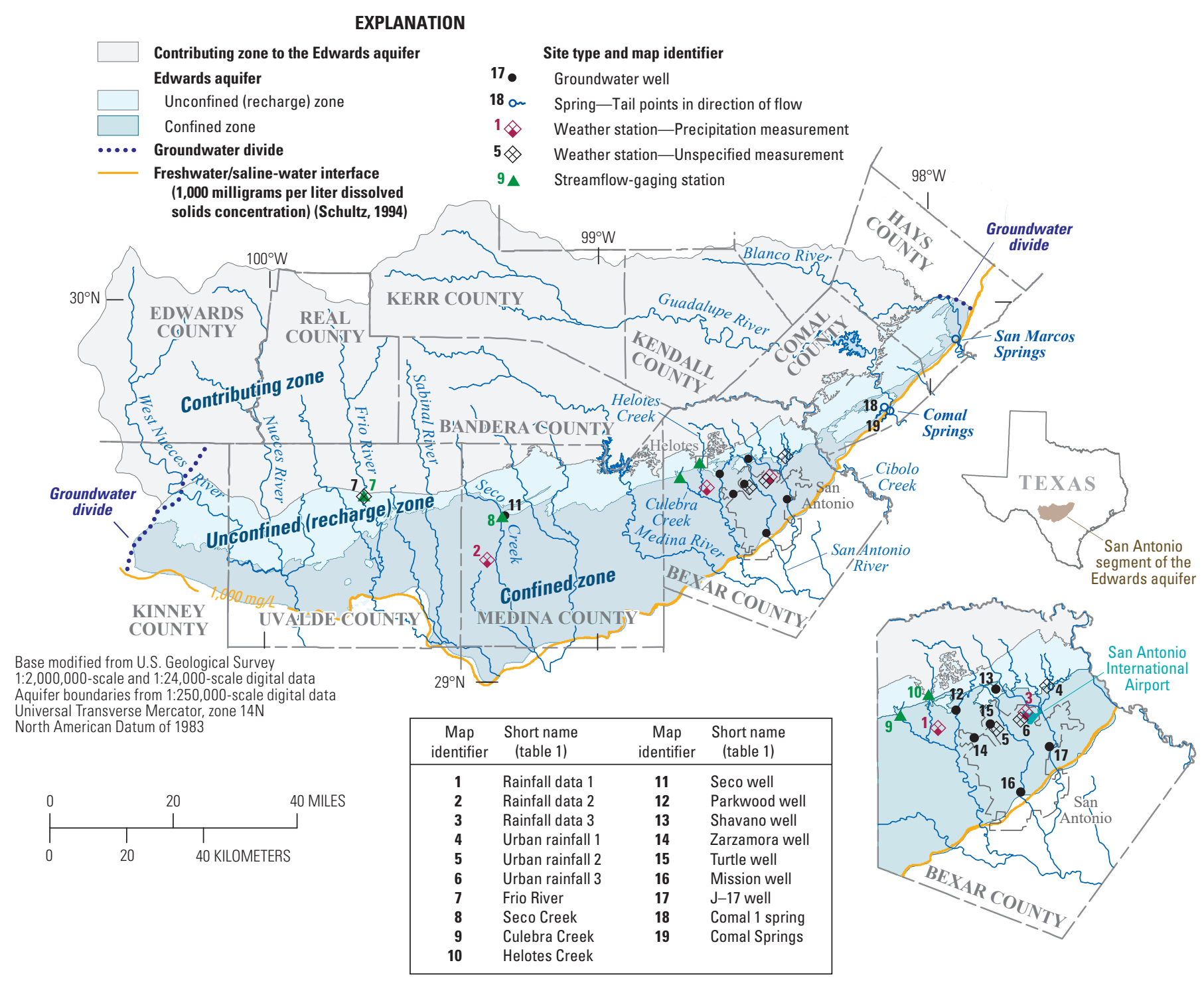

Figure 1. Hydrogeologic setting and site locations in the San Antonio segment of the Edwards aquifer, south-central Texas.

in the City of San Antonio and surrounding area (Greater Edwards Aquifer Alliance, 2014; Tremallo and others, 2015). The Edwards aquifer is both culturally and economically important to the region and provides recreational activities associated with springs and rivers (Edwards Aquifer Authority, 2017a). The Edwards aquifer also includes habitat that supports endemic species such as aquifer-dwelling animals and spring-dependent plants, many of which are classified as threatened or endangered (Edwards Aquifer Authority, 2017a). Water quality, recreational activities, and habitat of the Edwards aquifer can be compromised by the presence of various compounds of concern; therefore, there is a need to identify compounds of concern and better understand their sources, fate, and transport throughout the aquifer.

The Edwards aquifer is typical of karst aquifers, which are composed of soluble host rocks, usually carbonate rocks that have dissolved preferentially to form large voids and conduits (White, 1988). Karst features are characteristic of the Edwards aquifer and make the system susceptible to contamination because of the rapid transport of groundwater through high-porosity voids and conduits with little opportunity for subsurface filtration, sorption, or degradation of dissolved or particulate compounds (White, 1988). The Edwards aquifer recharge zone is particularly susceptible to contamination from the land surface because of the dynamic and rapid recharge that occurs through karst features such as sinkholes and losing streams during groundwater recharge events (Sharp and Banner, 1997). Dynamic recharge affects the timing and magnitude of changes in water quality - in particular nutrients and pesticides derived from anthropogenic sources. 
Previous water-quality studies of the Edwards aquifer have documented spatial and temporal variability in nutrient concentrations across the aquifer (Musgrove and others, 2010, 2011; Opsahl and others, 2017), which raises questions regarding the origin of nutrients. Nutrients, essential elements for plant and animal life, can have both natural and anthropogenic sources including rainfall, decomposing plants, soil erosion, human and animal wastes, inorganic and organic fertilizer, treated wastewater, and raw sewage (Dubrovsky and others, 2010). Nutrients can have deleterious effects on water quality especially if present at concentrations substantially elevated above natural levels. Nitrate $\left(\mathrm{NO}_{3}\right)$ in drinking water is a regulated contaminant with a maximum contaminant level of 10 milligrams per liter (mg/L) (U.S. Environmental Protection Agency, 2017b). Excess nitrogen $(\mathrm{N})$ in the form ammonia $\left(\mathrm{NH}_{4}\right)$ and $\mathrm{NO}_{3}$ in surface water promotes algal blooms (eutrophication), and decomposition of the algae consumes dissolved oxygen, causing other aquatic organisms to die (Rabalais and others, 2002; Ansari and others, 2010). The types and amounts of nutrients that might be introduced into the aquifer during groundwater recharge will likely vary because of land-use practices, among other factors. For example, nutrient pollution in the form of $\mathrm{NO}_{3}$ might be attributed to fertilizer in both rural (agriculture) and urban (landscaping) settings (Dubrovsky and others, 2010). In the Edwards aquifer, the proportion of nutrients derived from rural and urban sources relative to contributions from natural sources remains uncertain.

$\mathrm{NO}_{3}$ isotope values (delta nitrogen- 15 of nitrate $\left[\delta^{15} \mathrm{~N}-\mathrm{NO}_{3}\right]$ and delta oxygen- 18 of nitrate $\left[\delta^{18} \mathrm{O}-\mathrm{NO}_{3}\right]$ ) have been used to identify sources of $\mathrm{NO}_{3}$, distinguish groundwater flow paths, and provide information on biogeochemical processes that are relevant to tracing $\mathrm{NO}_{3}$ sources and sinks in groundwater systems (Clark and Fritz, 1997; Kendall, 1998; Kendall and others, 2014). The systematic relation between $\delta^{15} \mathrm{~N}^{-\mathrm{NO}_{3}}$ and $\delta^{18} \mathrm{O}-\mathrm{NO}_{3}$ in common $\mathrm{NO}_{3}$ sources, compiled from numerous studies, provides insight into sources of $\mathrm{NO}_{3}$ contributing to environmental samples (Kendall and others, 2014). For example, $\mathrm{NO}_{3}$ in synthetic fertilizers is distinguished from human and animal waste on the basis of lower $\delta^{15} \mathrm{~N}^{-\mathrm{NO}_{3}}$ values and higher $\delta^{18} \mathrm{O}-\mathrm{NO}_{3}$ values. $\mathrm{NO}_{3}$ in rainfall is clearly distinguished from other $\mathrm{NO}_{3}$ sources because of its high $\delta^{18} \mathrm{O}-\mathrm{NO}_{3}$ values and low $\delta^{15} \mathrm{~N}^{3} \mathrm{NO}_{3}$ values relative to surface-water and groundwater values. $\delta^{15} \mathrm{~N}^{-\mathrm{NO}_{3}}$ values that range from about 3 to 9 per mil are generally considered representative of a soil $\mathrm{NO}_{3}$ source. Numerous studies, however, have indicated that $\delta^{15} \mathrm{~N}^{-\mathrm{NO}_{3}}$ values in environmental samples between 3 and 10 per mil might result from a mixed source of possible contributors that include inorganic fertilizers, human and animal waste, and natural soil $\mathrm{NO}_{3}$ (Heaton, 1986; Wells and Krothe, 1989; Katz and others, 2004; Oren and others, 2004; Choi and others, 2007; Kendall and others, 2014). A broader understanding of the distribution of all $\mathrm{N}$ species and the associated biogeochemical transformations related to the formation and breakdown of $\mathrm{NO}_{3}$ can potentially enhance the use of $\delta^{15} \mathrm{~N}^{-\mathrm{NO}_{3}}$ and $\delta^{18} \mathrm{O}-\mathrm{NO}_{3}$ values for further determining potential $\mathrm{NO}_{3}$ sources in the Edwards aquifer.

The term "pesticides," as used in this study, refers to anthropogenic organic compounds and their degradates designed to kill or control plants (herbicides), insects (insecticides), fungi (fungicides), or other organisms, which are widely used in both rural and urban settings. Since the 1970s, less-persistent pesticides have been developed, and although they degrade more quickly than their predecessors, they are more soluble and frequently are detected in groundwater (Gilliom and others, 2006). Agricultural use of pesticides exceeds nonagricultural use, but nonagricultural use has been increasing since 1998 (Gilliom and others, 2006). Although pesticides are used in both rural and urban settings, the distribution of specific pesticides typically differs between rural and urban sources (Van Metre and others, 2016). Between 1992 and 2001, the herbicides most commonly detected in urban areas in the United States were prometon (streams) and atrazine (groundwater), and the insecticides most commonly detected in urban areas were diazinon (streams) and dieldrin (groundwater) (Gilliom and others, 2006). In agricultural areas, the herbicides most commonly detected between 1992 and 2001 were atrazine (streams) and its degradate deethylatrazine (also known as CIAT [2-Chloro-4-isopropylamino-6-amino-s-triazine] and hereinafter referred to as "DEA") (groundwater), and the insecticides most commonly detected were diazinon (streams) and carbofuran (groundwater) (Gilliom and others, 2006). However, the intensity of use of individual chemicals changes as new pesticides are introduced, as land-use practices change, and when their use is banned or curtailed. Data on pesticide use in agricultural areas (Gilliom and others, 2006) indicate that since 2000 only the use of atrazine has remained relatively steady - by 2014 use of prometon, diazinon, and carbofuran had decreased. Conversely, use of other herbicides, such as glyphosate, and insecticides, such as imidacloprid, has increased since 2000 (Gilliom and others, 2006).

Previous studies have documented the occurrence of pesticides in the Edwards aquifer (Bush and others, 2000; Fahlquist and Ardis, 2004; Musgrove and others, 2010). The pesticides most frequently detected throughout the aquifer in those studies were simazine, prometon, atrazine, and the atrazine degradate DEA, and these were detected most frequently in samples of unconfined groundwater collected at shallow urban wells. Musgrove and others (2010) reported that temporal variability in concentrations of these compounds was inconsistent among five wells with eight samples collected over 10 years, but that elevated concentrations of atrazine generally coincided with elevated water-level altitudes (waterlevel altitude is hereinafter referred to as "WLA").

Although the occurrence of nutrients and pesticides in both the unconfined and confined groundwater of the Edwards aquifer, as well as in surface-water recharge, has been documented (Bush and others, 2000; Fahlquist and Ardis, 2004; Musgrove and others, 2010; Opsahl, 2012), prior studies have not been designed to distinguish between 
different sources (rural versus urban), nor have they addressed how changes in hydrologic conditions influence water quality in the aquifer. Identifying geographic sources of nutrients and pesticides to the aquifer is further complicated by atmospheric inputs in rainfall, which can contribute both nutrients and pesticides with uncertain origins that may be either close to or distant from areas receiving rainfall (Nations and Hallberg, 1992; Hüskes and Levsen, 1997; Miller and others, 2000; Lajtha and Jones, 2013). The connectivity between water quality in groundwater recharge and deeper, confined water within the aquifer also has not been well characterized. In particular, understanding the role of surface-water and groundwater interaction and its effects on water quality under a range of hydrologic conditions, especially during periods of rapid groundwater recharge, is needed to inform that understanding. To address these questions, the U.S. Geological Survey, in cooperation with the San Antonio Water System, performed a study from 2010 to 2016 to better understand how water quality changes under a range of hydrologic conditions and in contrasting land-cover settings (rural and urban) in the Edwards aquifer. The wide range of hydrologic conditions that occurred during the study, from drought to wetter than normal, and geochemical processes occurring in the aquifer affected the occurrence, fate, and transport of nutrients and pesticides.

\section{Purpose and Scope}

The purpose of this report is to assess changes in selected water-quality constituents across the Edwards aquifer with an emphasis on the processes influencing nutrient and pesticide geochemistry and the factors affecting aquifer vulnerability. Differences in nutrients and pesticide concentrations during dry and wet conditions and for periods of base flow and stormwater runoff are described for rainfall, surface-water, and groundwater samples collected during 2010-16. The effects of different types of land cover (rural and urban) on the differences between water-quality constituents in surfacewater and groundwater samples are explored. Rural and urban sources of pesticides are evaluated along with how changes in hydrologic conditions influence water quality in the aquifer. Changes in WLAs between confined and unconfined parts of the aquifer are described in the context of changes in water quality and aquifer vulnerability.

\section{Hydrogeologic Framework}

The Edwards aquifer developed in heavily faulted, fractured, and karstified early Cretaceous-aged limestone and dolomitic rocks with extensive dissolution that yielded a porous matrix (Barker and Ardis, 1996). The aquifer is characterized by relatively high transmissivities (Lindgren, 2006). Typical of karst aquifers, most groundwater storage occurs within the aquifer matrix, but most transport occurs within conduits, which often dominate groundwater flow where present (White, 2002). The aquifer is present in a narrow band in south-central Texas - bounded at its western edge by a groundwater divide in Kinney County and at the northeastern edge by a groundwater divide in Hays County (fig. 1). Late Cenozoic faulting along the Balcones fault zone (fig. 2) formed a series of high-angle normal en echelon faults (Maclay and Small, 1983). The faulting resulted in a series of blocks of Edwards aquifer rocks that are offset and divide the confined and unconfined parts of the aquifer. The recharge zone (unconfined part of the aquifer) consists of about 1,250 square miles $\left(\mathrm{mi}^{2}\right)$ of Edwards Group limestone exposed at the surface (fig. 2) (Hamilton and others, 2008). The northern limit of the recharge zone (outcrop) defines the northern aquifer boundary (fig. 1). Downdip of the recharge zone, the aquifer becomes confined and is artesian. The aquifer is bounded to the south by the freshwater/saline-water interface, downgradient of which groundwater salinity rises rapidly (dissolved solids concentration exceeding 1,000 mg/L), and the water is considered unpotable (Schultz, 1994).

The majority of recharge to the Edwards aquifer occurs by direct infiltration from streams that drain the contributing zone (fig. 1) as they cross the recharge zone and discharge into the aquifer through open-solution channels (Puente, 1978; Maclay and Land, 1988). Intense storms with heavy rainfall are common, and flash flooding in streams greatly enhances groundwater recharge following storm events. Estimates of recharge from losing streams range from 60 to 80 percent (Klemt and others, 1979; Maclay and Land, 1988; Thorkildsen and McElhaney, 1992; Ockerman, 2005). Recharge is not evenly distributed across the aquifer; most recharge occurs from streams located in the western part of the aquifer (Puente, 1978). The remaining aquifer recharge comes from a combination of direct infiltration through the recharge zone and leakage from the underlying Trinity aquifer (fig. 2) into the Edwards aquifer (Sharp and Banner, 1997; Lindgren and others, 2004). Groundwater pumping in the San Antonio area has increased about fivefold since the 1930s, but WLA and spring discharge have not shown long-term declines because the aquifer readily recharges during periods of rainfall (Bush and others, 2000; Edwards Aquifer Authority, 2015).

The flow paths of recharge and regional groundwater in the Edwards aquifer are described in Maclay and Land (1988) and Clark and Journey (2006). Recharge water in the unconfined zone flows downdip to the confined zone (fig. 1). Regional groundwater flow is generally west to east from Kinney County through Uvalde, Medina, and Bexar Counties. The regional flow path shifts northeast through Comal and Hays Counties, where natural discharge occurs at large springs, predominantly Comal Springs and San Marcos Springs (Lindgren, 2006; Musgrove and Crow, 2012). Pumping for agriculture and municipal purposes also is a major component of discharge from the Edwards aquifer (Hamilton and others, 2008). 


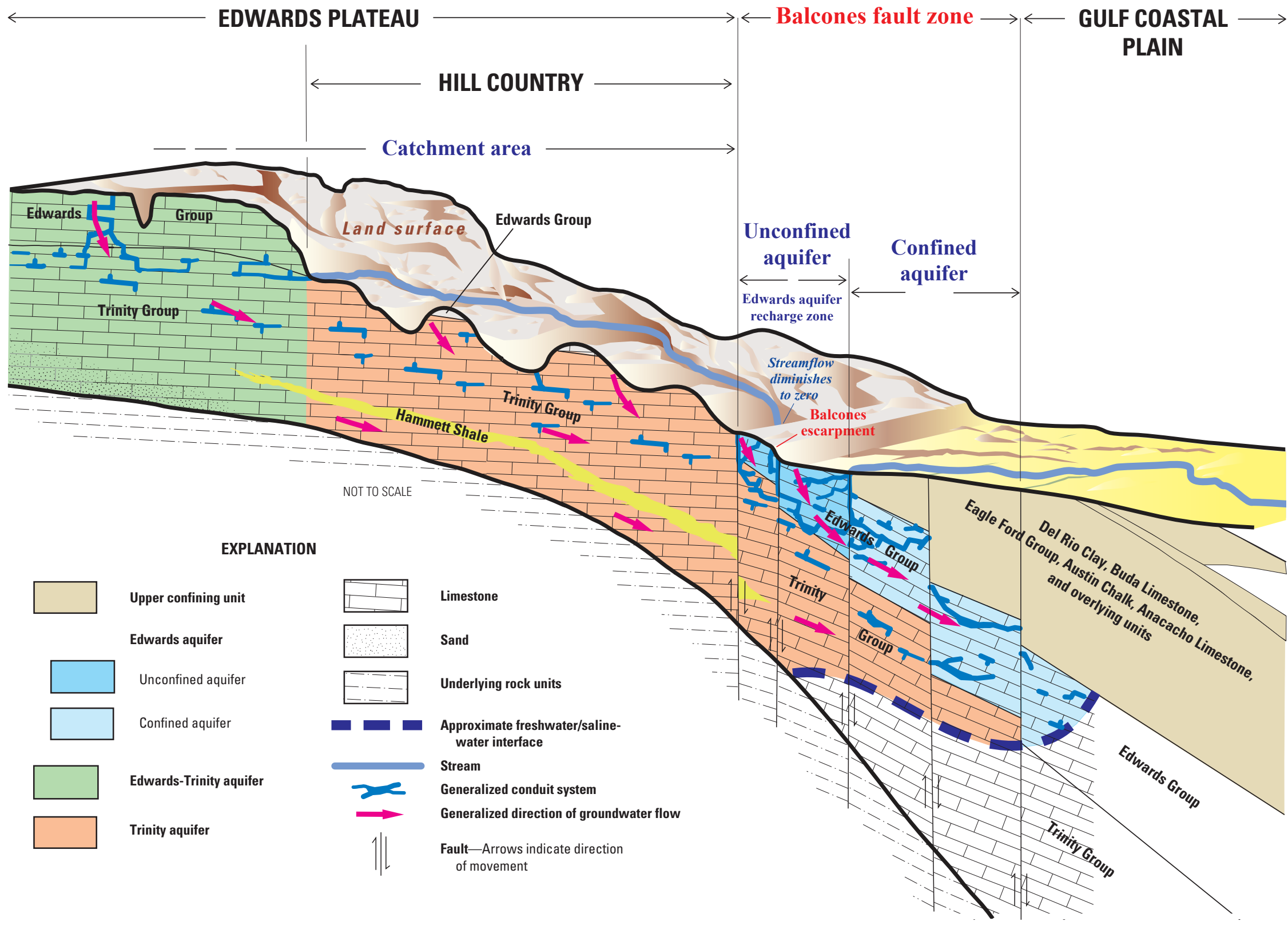




\section{Regional Land Cover}

As discussed in Musgrove and others (2010), regional land cover in the study area generally correlates with physiography. The contributing zone of the Edwards Plateau (fig. 1; shown as the catchment area in fig. 2) is characterized by thin soils and is predominantly undeveloped rangeland. There is little agriculture; agricultural lands are mostly to the west of San Antonio, over the confined aquifer, and what little agricultural land there is has decreased in recent years (Musgrove and others, 2016). Regional land cover is characterized as 3 percent agriculture, 6 percent urban, and 90 percent forest and rangeland (including shrub and grassland); the remaining 1 percent is water, wetlands, and barren land (Homer and others, 2001). San Antonio is the seventh largest city in the United States with a 2016 population of about 1.5 million (U.S. Census Bureau, 2017). The City of San Antonio is the principal urban area and includes much of Bexar County in the east-central part of the aquifer region. Bexar County is rapidly urbanizing, especially on San Antonio's north side in the aquifer's contributing and recharge zones. For example, while the population of Bexar County between 2000 and 2010 increased by 23 percent, growth in several north-side communities exceeded 50 percent (U.S. Census Bureau, 2017).

\section{Methods}

A monitoring network was designed to provide long-term geochemical data of water quality from rainfall, stream, and groundwater sites (fig. 1; table 1). Rainfall, surface-water, and groundwater samples were collected over a period of approximately three and a half years (July 2013 through December 2016) at different sites throughout the study area. Site selection took into account different land-cover types (rural and urban environments) and included unconfined zone (relatively shallow) and confined zone (relatively deep) groundwater wells (fig. 1). All sites will hereinafter be referred to by their short names (table 1).

\section{Study Design}

The study design built upon knowledge gained from previous studies of water quality in the region (including Mahler and others, 2006, 2011a, b; Musgrove and others, 2010, 2011; Opsahl, 2012). The study design included continuous hydrologic and water-quality monitoring (stream discharge, WLA, specific conductance in microsiemens per centimeter at 25 degrees Celsius [hereinafter referred to as "SC"], and $\mathrm{NO}_{3}$ concentration) and discrete sample collection for a detailed characterization of water quality at a network of sites throughout the aquifer system. The sites were selected to encompass a "source-to-sink" (that is, from aquifer recharge to aquifer discharge) approach. Network sites were selected to characterize rainfall, recharging surface water, and groundwater; groundwater sites included wells in the unconfined part of the aquifer (unconfined wells) and in the confined part of the aquifer (confined wells) and a major discharging spring. Stormwater-runoff (surfacewater) and storm-response (groundwater) samples also were included to characterize water quality in response to rainfall and recharge-generating storms, and thus, the frequency of water-quality sample collection was higher during periods of rapid hydrologic change. Rainfall samples were collected for water-quality analyses at the Frio River (representative of rural land cover) and at three separate sites located within the City of San Antonio (representative of urban land cover) (fig. 1). All surface-water sites are ephemeral, although the Frio River ceases to flow only during periods of prolonged drought. Seco Creek, Culebra Creek, and Helotes Creek are typically dry and flow only for intermittent periods following relatively large storm events. Rural surface-water sites included the Frio River, Seco Creek, and Culebra Creek. Helotes Creek was selected as representative of urban surface water on the basis of increasing urbanization in its watershed (Opsahl, 2012). Seco well was selected to represent unconfined groundwater in the rural portion of the system, and Parkwood well was selected to represent urban unconfined groundwater. Zarzamora well was selected to represent urban confined (deeper) groundwater. Comal 1 spring, located near the downgradient end of the regional flow path (fig. 1), was selected to represent an integrator of regional aquifer groundwater quality (Musgrove and Crow, 2012) and, for the purposes of this report, will hereinafter be considered as groundwater. In addition, selected sites from a complementary Enhanced Trends Network (ETN) study by the U.S. Geological Survey National Water Quality Assessment (NAWQA) project also were used in this study. The ETN sites, all within the City of San Antonio, include an unconfined urban well (Shavano well), a confined urban production well (Turtle well), and a deeper, confined urban production well that is artesian (the Mission well) located further downdip and close to the freshwater/saline-water interface (fig. 1). The placement of continuous-monitoring sensors considered the water chemistry of the Edwards aquifer, which is generally well mixed vertically, consistent with the porous karst properties and high transmissivities of the aquifer (Lindgren, 2006; Musgrove and others, 2010, 2011). Continuous-monitoring sensors were positioned within the screened interval in each well (with the exception of the Mission well and the Turtle well), and data from these wells are assumed to be representative of the entire saturated zone for each site. Groundwater samples were collected from unconfined wells completed in the recharge zone of the aquifer and from confined wells completed in the deeper part of the aquifer. Groundwater wells in the unconfined zone of the aquifer (hereinafter referred to as "unconfined wells") were selected to characterize the rapid changes in WLA and water quality that occur during groundwater recharge, and groundwater wells in the confined zone (hereinafter referred to as "confined wells") were selected to represent the part of 
the aquifer system that responds more slowly to groundwater recharge. The spatial and temporal differences in sample collection provided an opportunity to investigate processes affecting the fate and transport of nutrients and pesticides within the Edwards aquifer. The types of data collected for this study included continuous monitoring of physiochemical parameters, continuous monitoring of water-quality parameters, water-quality data from discretely collected samples, and ancillary climatological and hydrologic data to help interpret the geochemical data, all of which are described below and summarized in table 1 . Not all data collected during the study are included in this report; however, all data are available for download in a companion data release (Opsahl and others, 2018).

\section{Rainfall Data}

Daily rainfall data were obtained for the study period from meteorological sites near some of the sampled wells (Seco well and Parkwood well) and the San Antonio International Airport (fig. 1; table 1). Daily rainfall data were acquired from the Global Historical Climatology Network (GHCN) (Menne and others, 2012; National Oceanic and Atmospheric Administration, 2017a). During the study period, no rainfall data were reported for 12 days of the record for Rainfall data 2 (located near Seco well). GHCN site US1TXMDN041 (National Oceanic and Atmospheric Administration, 2017a), the next nearest GHCN site to the Rainfall data 2 and Seco well, is located about 5.6 miles (mi) southeast of Seco well. No rainfall was reported at GHCN site US1TXMDN041 for those corresponding dates with two exceptions where no data were available from Rainfall data 2 or GHCN site US1TXMDN041 on June 7, 2015, and December 30, 2016 (National Oceanic and Atmospheric Administration, 2017a). No rainfall was recorded regionally on June 7, 2015, or December 30, 2016 (National Oceanic and Atmospheric Administration, 2017b), so rainfall was assumed to be zero. No rainfall data were available for 16 days of the record for Rainfall data 1 (located near Parkwood well). GHCN site US1TXBXR287 (National Oceanic and Atmospheric Administration, 2017a), the next nearest GHCN site to Rainfall data 1 and Parkwood well, is located about 3.7 mi southwest of Parkwood well. Rainfall was reported for five of those dates, and daily rainfall values from GHCN site US1TXBXR287 were substituted to supplement the record for Rainfall data 1 (0.07 inches [in.] on January 1, 2015; 0.02 in. on June 14, 2015; 2.30 in. on June 15, 2015; 0.25 in. on June 17, 2015; and 0.03 in. on January 1, 2016). No rainfall data were available from Rainfall data 1 or US1TXBXR287 for June 28, 2016 (National Oceanic and Atmospheric Administration, 2017a). No rainfall was reported regionally on June 28, 2016 (National Oceanic and Atmospheric Administration, 2017b), so rainfall was assumed to be zero on June 28, 2016. The rainfall record for the San Antonio International Airport was complete for the study period.

\section{Streamflow Measurements}

Streamflow-gaging stations at Culebra Creek, Helotes Creek, and Frio River (fig. 1; table 1) are operated as part of an existing network of cooperatively funded USGS streamflow-gaging stations. Stage at each surface-water site was recorded every 15 minutes and transmitted hourly by the Geostationary Operational Environmental Satellite (GOES) transmitter to the USGS National Water Information System (NWIS) database (U.S. Geological Survey, 2017). Discharge for Helotes Creek and the Frio River is computed from the 15 -minute stage data by using a stage-discharge relation unique to each surface-water site. The streamflow-gaging stations are visited periodically to verify the recorded stage and obtain measurements of flow, used to verify the stagedischarge relation (Rantz and others, 1982a; Turnipseed and Sauer, 2010). The information obtained during the periodic site visits is applied to update the record (and stage-discharge relation, as needed) and to compute continuous discharge (Rantz and others, 1982b; Kennedy, 1983, 1984; Sauer and Turnipseed, 2010), which is stored in the NWIS database (U.S. Geological Survey, 2017). Seco Creek (fig. 1; table 1) is a previously established USGS streamflow-gaging station that was used only for periodic water-quality sample collection in this study. The Culebra Creek site reports only stage data because there are too few discharge measurements to date (December 2017) to develop a stage-discharge relation.

\section{Continuous Water-Level Altitude Measurements}

Continuous WLA data were collected from Seco well, Parkwood well, Shavano well, and Zarzamora well (fig. 1; table 1) by using methods described by Cunningham and Schalk (2011). The wells were equipped with a submersible pressure transducer, data recorder, and GOES transmitter. Water-level data were recorded in feet below a known land surface datum at 15-minute intervals and periodically verified against a calibrated water-level tape and corrected as required. The 15-minute water-level data were transmitted hourly via GOES to the NWIS database (U.S. Geological Survey, 2017). In NWIS, the water-level data were then converted to WLA data by using either the National Geodetic Vertical Datum of 1929 (NGVD 1929) or the North American Vertical Datum of 1988 (NAVD 1988) reference datum.

\section{Continuous Water-Quality Monitoring}

Continuous water-quality monitoring began in July 2013 and continued through December 2016, although the exact beginning dates for different data types varied among sites. For all wells equipped with in-situ water-quality sensors (Seco, Parkwood, Shavano, and Zarzamora wells), placement was at approximate depths shown in table 1. Prior information for Seco well including vertical profiling of SC, temperature, and vertical flow logging (Opsahl and others, 2017) was used 
Table 1. Sites where hydrologic data were obtained and water-quality samples were collected in the San Antonio segment of the Edwards aquifer, south-central Texas, 2010-16.

[GHCN, Global Historical Climatology Network; USGS, U.S. Geological Survey; EAA, Edwards Aquifer Authority; dd, decimal degrees referenced to North American Datum of 1983; ft, foot; NAVD 88, North American Vertical Datum of 1988; SSE, south southeast; TX, Texas; US, United States; NA, not applicable; RF, daily rainfall total; WSW, west southwest; QWrf, rainfall water quality; SF, streamflow; QWp, periodic water quality; QWs, stormflow-runoff water quality; QWc, continuous water quality; QWn, continuous nitrate water quality; FM, farm to market road; WLA, water-level altitude; --, not available]

\begin{tabular}{|c|c|c|c|c|}
\hline $\begin{array}{c}\text { Map } \\
\text { identi- } \\
\text { fier } \\
\text { (fig. 1) }\end{array}$ & Site type & $\begin{array}{l}\text { GHCN, USGS, or EAA } \\
\text { station number }\end{array}$ & $\begin{array}{l}\text { GHCN, USGS, or } \\
\text { EAA station name }\end{array}$ & $\begin{array}{l}\text { Short } \\
\text { name } \\
\text { (fig. 1) }\end{array}$ \\
\hline 1 & Weather station & ${ }^{1}$ US1TXBXR095 & Helotes 3.7 SSE TX US & Rainfall data 1 \\
\hline 2 & Weather station & ${ }^{1}$ US1TXMDN021 & D HANIS 3.5 WSW TX US & Rainfall data 2 \\
\hline 4 & Rainfall-collection station & ${ }^{2} 293537098261500$ & EARZ Urban Precipitation Site 1 at San Antonio, Tex. & Urban rainfall 1 \\
\hline 5 & Rainfall-collection station & ${ }^{2} 293044098325100$ & EARZ Urban Precipitation Site 2 at San Antonio, Tex. & Urban rainfall 2 \\
\hline 6 & Rainfall-collection station & ${ }^{2} 88480701$ & USGS South Texas Program Office at San Antonio, Tex. & Urban rainfall 3 \\
\hline 7 & $\begin{array}{l}\text { Streamflow-gaging and } \\
\text { rainfall-collection station }\end{array}$ & ${ }^{2} 08195000$ & Frio River at Concan, Tex. & Frio River \\
\hline 10 & Streamflow-gaging station & ${ }^{2} 08181400$ & Helotes Creek at Helotes, Tex. & Helotes Creek \\
\hline 11 & Groundwater well ${ }^{3}$ & ${ }^{2} 292618099165901$ & Seco Creek Well & Seco well \\
\hline 12 & Groundwater well ${ }^{3}$ & ${ }^{2} 293252098380801$ & AY-68-27-610 (Parkwood Park) & Parkwood well \\
\hline 13 & Groundwater well ${ }^{3}$ & ${ }^{2} 293516098325501$ & Shavano Park at Fawn Drive & Shavano well \\
\hline 14 & Groundwater well ${ }^{4}$ & ${ }^{2} 292943098354404$ & AY-68-36-132 (Z DED) & Zarzamora well \\
\hline 15 & Groundwater well ${ }^{4}$ & ${ }^{2} 293116098334101$ & Turtle Creek 3 & Turtle well \\
\hline 16 & Groundwater well ${ }^{4}$ & ${ }^{2} 292331098294501$ & Mission 7 & Mission well \\
\hline 17 & Groundwater well ${ }^{4}$ & ${ }^{5} 6837203$ & Bexar County index well (J-17) & $\mathrm{J}-17$ well \\
\hline 18 & Spring & ${ }^{2} 294300098080001$ & Comal 1 & Comal 1 spring \\
\hline
\end{tabular}


Table 1. Sites where hydrologic data were obtained and water-quality samples were collected in the San Antonio segment of the Edwards aquifer, south-central Texas, 2010-16. - Continued

[GHCN, Global Historical Climatology Network; USGS, U.S. Geological Survey; EAA, Edwards Aquifer Authority; dd, decimal degrees referenced to North American Datum of 1983; ft, foot; NAVD 88, North American Vertical Datum of 1988; SSE, south southeast; TX, Texas; US, United States; NA, not applicable; RF, daily rainfall total; WSW, west southwest; QWrf, rainfall water quality; SF, streamflow; QWp, periodic water quality; QWs, stormflow-runoff water quality; QWc, continuous water quality; QWn, continuous nitrate water quality; FM, farm to market road; WLA, water-level altitude; --, not available]

\begin{tabular}{|c|c|c|c|c|c|c|c|}
\hline $\begin{array}{l}\text { Map } \\
\text { identi- } \\
\text { fier } \\
\text { (fig. 1) }\end{array}$ & $\begin{array}{l}\text { Latitude } \\
\text { (dd) }\end{array}$ & $\begin{array}{l}\text { Longitude } \\
\text { (dd) }\end{array}$ & $\begin{array}{c}\text { Elevation of } \\
\text { land surface } \\
\text { (ft above } \\
\text { NAVD 88) }\end{array}$ & $\begin{array}{l}\text { Well depth } \\
\text { (ft below land } \\
\text { surface) }\end{array}$ & $\begin{array}{c}\text { Water- } \\
\text { quality } \\
\text { sensor } \\
\text { depth } \\
\text { (ft below } \\
\text { land surface) }\end{array}$ & $\begin{array}{c}\text { Nitrate } \\
\text { sensor } \\
\text { depth } \\
\text { (ft below } \\
\text { land surface) }\end{array}$ & Data type \\
\hline 1 & 29.51694 & 98.67500 & NA & NA & NA & NA & $\mathrm{RF}$ \\
\hline 2 & 29.32611 & 99.33778 & NA & NA & NA & NA & $\mathrm{RF}$ \\
\hline 3 & 29.54444 & 98.48389 & NA & NA & NA & NA & $\mathrm{RF}$ \\
\hline 4 & 29.59362 & 98.43750 & NA & NA & NA & NA & QWrf \\
\hline 5 & 29.51218 & 98.54738 & NA & NA & NA & NA & QWrf \\
\hline 6 & 29.52967 & 98.49502 & NA & NA & NA & NA & QWrf \\
\hline 7 & 29.48856 & 99.70478 & NA & NA & NA & NA & $\begin{array}{l}\text { SF, QWp, QWs, QWc, QWn, } \\
\text { QWrf }\end{array}$ \\
\hline 8 & 29.43967 & 99.28489 & NA & NA & NA & NA & QWp \\
\hline 9 & 29.53917 & 98.75139 & NA & NA & NA & NA & QWs \\
\hline 10 & 29.57856 & 98.69169 & NA & NA & NA & NA & SF, QWs \\
\hline 11 & 29.43857 & 99.28337 & $1,008.7$ & 538 & 370 & 380 & WLA, QWp, QWc, QWn \\
\hline 12 & 29.54778 & 98.63556 & 896 & 229 & 205 & 210 & WLA, QWp, QWc, QWn \\
\hline 13 & 29.58778 & 98.54861 & 975 & 300 & 270 & 295 & WLA, QWp, QWc, QWn \\
\hline 14 & 29.49528 & 98.59556 & 848 & 596.5 & 590 & NA & WLA, QWp \\
\hline 15 & -- & -- & 946 & 550 & NA & NA & QWp, QWc \\
\hline 16 & -- & -- & 585 & 1,500 & NA & NA & QWp, QWc \\
\hline 17 & 29.47917 & 98.43250 & ${ }^{6} 730.8$ & 874 & NA & NA & WLA \\
\hline 18 & 29.71278 & 98.13750 & NA & NA & NA & NA & QWp, QWc \\
\hline 19 & 29.70606 & 98.12251 & NA & NA & 1 & NA & $\mathrm{SF}$ \\
\hline
\end{tabular}

${ }^{1} \mathrm{GHCN}$ station.

${ }^{2}$ USGS station.

${ }^{3}$ Groundwater well completed in the unconfined part of the aquifer.

${ }^{4}$ Groundwater well completed in the confined part of the aquifer.

${ }^{5}$ EAA station.

${ }^{6}$ Bexar County index well (J-17) water-level altitudes are reported and referenced to the National Geodetic Vertical Datum of 1929. 
to identify the most productive zone (about 360 feet [ft] below land surface). Vertical flow in this well was downward, and the sensors were placed $360 \mathrm{ft}$ below land surface to monitor this more productive water-bearing zone. At Parkwood and Shavano wells, sensors were placed near the bottoms of these wells, which were likely to be the more water-bearing zones based on stratigraphy and well logs. At Zarzamora well, sensors were placed midway in the screened interval (between 586 and $597 \mathrm{ft}$ below land surface), a depth typical of surrounding production wells. Notably, all wells are situated in a porous karst setting, and although detailed vertical profiling was not included in the study design, prior studies have indicated that wells in this setting are vertically well mixed (Lindgren, 2006; Musgrove and others, 2011; Opsahl and others, 2017). Shavano well, Mission well, Turtle well, and Comal 1 spring were instrumented with multiparameter EXO 1 water-quality sensors (YSI Incorporated) to collect water temperature, SC, dissolved oxygen concentration, and $\mathrm{pH}$ data. The Mission and Turtle wells were instrumented ex situ; that is, the water-quality sensors measure a stream of water that is diverted at the well head and passes through a flowthrough chamber when the wells are pumping or flowing. At Comal 1 spring, the water-quality sensor was placed into the spring orifice. Seco, Parkwood, and Zarzamora wells were instrumented in situ with YSI OMS600 water-quality sensors placed downhole in the water column to measure SC and water temperature. The water-quality sensors were maintained with periodic field visits to clean and calibrate the instruments by using methods described by Wagner and others (2006).

Continuous monitoring of $\mathrm{NO}_{3}$ was implemented at Seco well in July 2014, Parkwood well in September 2014, and the Frio River in September 2015 by using submersible ultraviolet nitrate analyzer (SUNA) sensors (Sea-bird Scientific, 2018). The measuring principle of the $\mathrm{NO}_{3}$ sensors used in this study is based on optical absorption (Pellerin and others, 2013). $\mathrm{NO}_{3}$ and nitrite $\left(\mathrm{NO}_{2}\right)$ have similar absorption properties, and the sensors detect both compounds as part of the measurement. However, $\mathrm{NO}_{2}$ concentrations in the types of water monitored in this study are uniformly low (Opsahl and others, 2017), and the $\mathrm{NO}_{3}$-sensor values reported in this study will hereinafter be referred to as " $\mathrm{NO}_{3}$ concentrations." The $\mathrm{NO}_{3}$ sensors were maintained with periodic field visits to clean and verify the calibration by using methods described by Pellerin and others (2013). The precision of the $\mathrm{NO}_{3}$ sensor is plus or minus $0.07 \mathrm{mg} / \mathrm{L}$ with a 95 percent confidence interval (Opsahl and others, 2017). High turbidity prevents adequate light transmission through the flow cell of the instrument (Pellerin and others, 2013), and $\mathrm{NO}_{3}$ values recorded following storms at the Frio River were censored from the dataset until a minimum criterion for light transmission was again met.

Continuous water-quality and streamflow data were collected at 15 -minute intervals, with the exception of $\mathrm{NO}_{3}$, for which data were collected at hourly intervals; these data are referred to as unit values and were transmitted hourly via GOES to the NWIS database (U.S. Geological Survey, 2017).
The data records for Turtle and Mission production wells were intermittent throughout the monitoring period, providing reliable data only when the wells were being pumped (Turtle) or flowing unimpeded (Mission). Daily median values for streamflow, WLA, $\mathrm{SC}$, and $\mathrm{NO}_{3}$ and streamflow were computed from the available unit values.

\section{Discrete Water-Quality Sample Collection}

The exact period of water-quality sample collection varied among the different sites, but the majority of sampling occurred between July 2013 and December 2016. There were a few samples that were collected earlier than July 2013, including one stormwater-runoff sample from Culebra Creek in April 2010, four stormwater-runoff samples from Helotes Creek between October 2011 and May 2013, and two urban rainfall samples collected in January 2012 from site Urban rainfall 3 (table 1). Samples collected earlier than July 2013 represent sample types that are particularly difficult to collect (for example, ephemeral streams, which rarely flow). These additional measurements were based on the same collection techniques and analytical methods as the rest of the samples in this study and are included to expand the available data for these sites.

During July 2013 through December 2016, the frequency of routine sampling for the Frio River and three groundwater sites (Seco, Parkwood, and Zarzamora) was about every 6-8 weeks. Sites that were part of the ETN network (Shavano, Turtle, and Mission wells) were sampled from November 2013 through December 2016. The sampling frequency at the ETN sites was about every 6-10 weeks, similar to the other sites in the network, though sometimes longer. Routine samples from all sites were collected without regard to hydrologic conditions. Storm-related samples-including rainfall samples, stormwater-runoff (surface-water) samples, and groundwater samples - were collected to characterize the aquifer response to recharge. These samples were collected opportunistically as conditions permitted. Rainfall samples were dependent on storm events, surface-water samples were dependent on increased streamflow following storm events, and groundwater samples were dependent on rising water levels following rainfall and recharge events. As a result, storm-related samples were collected at different times for different sites.

Rainfall samples were collected by following standard USGS methods documented in the "National Field Manual for the Collection of Water-Quality Data" (U.S. Geological Survey, variously dated). Rainfall samples were collected at four sites, three in the urban San Antonio area (multiple sites in proximity were used to accommodate sampling logistics and site availability) and one in the rural western part of the aquifer region (fig. 1; table 1). Rainfall was collected by using a bulk rainfall collector consisting of a stainless steel funnel that emptied into a polyethylene container. The rainfall collectors were placed at the respective locations prior to an 
imminent rainfall event, and the samples were retrieved as soon as practical following the event. Each rainfall sample was a single-composite sample representing the average water quality of collected rainfall for the event. Samples were placed on ice and transported to the USGS South Texas Program Office Laboratory in San Antonio for processing.

Routine and storm-runoff samples were collected from the Frio River by following procedures outlined in the USGS "National Field Manual for the Collection of Water-Quality Data" (U.S. Geological Survey, variously dated). Prior to sampling, field parameters including water temperature, dissolved oxygen concentration, $\mathrm{pH}$, turbidity, and $\mathrm{SC}$ were monitored until they had stabilized and recorded just prior to sample collection (Wilde, variously dated). For routine samples at the Frio River, stream depths were shallow enough to be waded, and samples were collected by using a US DH-81 with a 1-liter Teflon bottle sampler attached to a wading rod as described by Davis (2005). Storm-runoff samples from the Frio River and the two other surface-water sites (Culebra Creek and Helotes Creek) were collected by using ISCO 3700 autosamplers (Teledyne Isco, 2018) because these sites are not wadable during flash floods. For samples collected by using the autosamplers (Frio River and Helotes Creek only), flow-weighted stormwater-runoff samples were composited by using a point-integrated sampling method. A point-integrated sample is a sample accumulated continuously in a sampler that is held at a relatively fixed point and that admits a water and sediment mixture at a velocity about equal to the instantaneous stream velocity at that point (Burkham, 1985). Each sample was drawn through a fixed intake mounted at the midpoint in the stream channel by using a suction-lift automatic sampler. The automatic sampler was programmed to begin sampling at a predetermined stage that was selected to ensure that streamflow was occurring. The autosampler was programmed to collect 500-milliliter samples every 15 minutes (Helotes Creek) or 60 minutes (Frio River) and sequentially fill each of four 8-liter bottles during the runoff event. The difference in sampling intervals between the two sites was needed because stormwater-runoff events at Helotes Creek are typically of much shorter duration than those at the Frio River. The samples were retrieved at the end of each runoff event or as soon as practical after all bottles were filled. The samples were then placed on ice and transported to the USGS South Texas Program Office Laboratory in San Antonio for processing. The four 8-liter samples collected by the automatic sampler were flow- or stage-weighted and composited into a single water-quality sample to represent the event mean concentration. Samples collected by wading or autosamplers were composited into a Teflon churn. Subsamples for specific analysis were withdrawn from the churn and preserved as required by the analyzing laboratory. Not all stormwaterrunoff samples, however, could be collected as flow- or stageweighted composites because of variations in rainfall causing flows of extended duration, occurrence of multiple discharge peaks, mechanical problems with autosamplers, an insufficient number of autosamplers for deployment at all of the sites prior to a runoff event, or lack of discharge data. In some instances, multiple grab samples were collected from the edge of the stream or bridge and composited into a single waterquality sample. Compound concentrations from multiple grab samples represent instantaneous event concentrations. For the purposes of this report, all storm-runoff samples are considered to represent instantaneous event concentrations and are not used to compute longer term loadings of individual compounds.

Routine groundwater samples were collected as described in the USGS "National Field Manual for the Collection of Water-Quality Data" (U.S. Geological Survey, variously dated) at Seco, Parkwood, Shavano, Zarzamora, Turtle, and Mission wells, as well as Comal 1 spring, without regard to hydrologic conditions (fig. 1; table 1). In addition to routine sampling, some samples at unconfined wells were collected in response to recharge-generating storms and corresponding rises in WLAs. At Seco, Parkwood, and Zarzamora wells, a pump was lowered into the well for sampling. At Shavano well, a pump was permanently installed in situ. Prior to sample collection at Seco, Parkwood, Shavano, and Zarzamora wells, three casing volumes were purged to ensure that water from the formation was being collected. During purging, field parameters including water temperature, dissolved oxygen concentration, $\mathrm{pH}$, turbidity, and SC were monitored until they had stabilized and were recorded just prior to sample collection (Wilde, variously dated). At Turtle and Mission wells, samples were collected directly at the well head and did not undergo any treatment prior to collection. Samples from Comal 1 spring were collected by immersing bottles below the water surface into or near the spring orifice, avoiding contact with the atmosphere and standing surface water. Samples were either processed immediately in the field or placed on ice and transported to the USGS South Texas Program Office in San Antonio for processing.

\section{Analytical Methods}

Most water-quality samples were analyzed for alkalinity, major ions, nutrients, pesticides and pesticide degradates, and selected environmental isotopes including stable isotopes of water (delta deuterium [ $\delta \mathrm{D}]$ and $\delta^{18} \mathrm{O}$ ), stable isotopes of $\mathrm{NO}_{3}\left(\delta^{15} \mathrm{~N}-\mathrm{NO}_{3}\right.$ and $\left.\delta^{18} \mathrm{O}-\mathrm{NO}_{3}\right)$, and strontium $(\mathrm{Sr})$ isotopes (strontium-87 [ $\left.{ }^{87} \mathrm{Sr}\right] /$ strontium-86 [ $\left.{ }^{86} \mathrm{Sr}\right]$ ). Not all samples were analyzed for all constituents; specifically, most samples from Shavano, Turtle, and Mission wells (the ETN sites) were not analyzed for pesticides and pesticide degradates. Where analyzed for pesticides, samples from the ETN sites were analyzed with a different analytical method. As a result, the ETN sites are not considered in the pesticide discussion in this report. All laboratory methods used for analysis of waterquality samples are listed in table 2. 


\section{Water-Quality Observations of the San Antonio Segment of the Edwards Aquifer, Texas}

Table 2. Measured constituents, laboratory reporting levels, units, method references, and analyzing laboratories for water-quality samples collected from sites in the San Antonio segment of the Edwards aquifer, south-central Texas, 2010-16.

[N, nitrogen; mg/L, milligram per liter; NWQL, National Water Quality Laboratory of the U.S. Geological Survey; TKN, total Kjeldahl nitrogen; $\mu \mathrm{g} / \mathrm{L}$, microgram per liter; --, not applicable; LRL, laboratory reporting level; P, phosphorus; $\mu \mathrm{S} / \mathrm{cm}$, microsiemens per centimeter at 25 degrees Celsius; MMIL, Metal and Metalloid Isotope Laboratory of the U.S. Geological Survey; $\delta^{18} \mathrm{O}$, delta oxygen-18; RSIL, Reston Stable Isotope Laboratory of the U.S. Geological Survey; $\delta \mathrm{D}$, deuterium; $\delta^{15} \mathrm{~N}-\mathrm{NO}_{3}$, delta nitrogen-15 in nitrate; $\delta^{18} \mathrm{O}-\mathrm{NO}_{3}$, delta oxygen-18 in nitrate]

\begin{tabular}{|c|c|c|c|c|}
\hline Constituent & $\begin{array}{l}\text { Laboratory } \\
\text { reporting level }\end{array}$ & Unit & $\begin{array}{l}\text { Method } \\
\text { reference }\end{array}$ & $\begin{array}{l}\text { Analyzing } \\
\text { laboratory }\end{array}$ \\
\hline Ammonia as $\mathrm{N}$, filtered & 0.01 & $\mathrm{mg} / \mathrm{L}$ & Fishman, 1993 & NWQL \\
\hline Ammonia plus organic nitrogen as $\mathrm{N}$, filtered & 0.07 & $\mathrm{mg} / \mathrm{L}$ & Patton and Truitt, 2000 & NWQL \\
\hline $\begin{array}{l}\text { Ammonia plus organic nitrogen as } \mathrm{N} \text {, } \\
\text { unfiltered (TKN) }\end{array}$ & 0.07 & $\mathrm{mg} / \mathrm{L}$ & Patton and Truitt, 2000 & NWQL \\
\hline Bicarbonate, filtered & 1 & $\mathrm{mg} / \mathrm{L}$ & Rounds, 2006 & $\begin{array}{l}\text { Analyzed } \\
\text { in the } \\
\text { field }\end{array}$ \\
\hline Boron, filtered & 2.0 & $\mu \mathrm{g} / \mathrm{L}$ & Struzeski and others, 1996 & NWQL \\
\hline Bromide, filtered & 0.01 & $\mathrm{mg} / \mathrm{L}$ & Fishman and Friedman, 1989 & NWQL \\
\hline Calcium, filtered & 0.022 & $\mathrm{mg} / \mathrm{L}$ & Fishman, 1993 & NWQL \\
\hline Chloride, filtered & 0.02 & $\mathrm{mg} / \mathrm{L}$ & Fishman and Friedman, 1989 & NWQL \\
\hline Fluoride, filtered & 0.01 & $\mathrm{mg} / \mathrm{L}$ & Fishman and Friedman, 1989 & NWQL \\
\hline Magnesium, filtered & 0.011 & $\mathrm{mg} / \mathrm{L}$ & Fishman, 1993 & NWQL \\
\hline Nitrate plus nitrite as $\mathrm{N}$, filtered & 0.01 & $\mathrm{mg} / \mathrm{L}$ & Patton and Kryskalla, 2011 & NWQL \\
\hline Nitrite as N, filtered & 0.001 & $\mathrm{mg} / \mathrm{L}$ & Fishman, 1993 & NWQL \\
\hline $\mathrm{pH}$, unfiltered, lab & 0.1 & $\mathrm{pH}$ unit & Fishman, 1993 & NWQL \\
\hline Orthophosphate as P, filtered & 0.004 & $\mathrm{mg} / \mathrm{L}$ & Fishman, 1993 & NWQL \\
\hline Pesticide and pesticide degradates, filtered & $\begin{array}{l}\text { Individual LRLs } \\
\text { provided in Opsahl } \\
\text { and others (2018) }\end{array}$ & $\mu \mathrm{g} / \mathrm{L}$ & Zaugg and others, 1995 & NWQL \\
\hline Phosphorus as $\mathrm{P}$, filtered & 0.01 & $\mathrm{mg} / \mathrm{L}$ & Patton and Kryskalla, 2003 & NWQL \\
\hline Phosphorus as $\mathrm{P}$, unfiltered & 0.01 & $\mathrm{mg} / \mathrm{L}$ & Patton and Kryskalla, 2003 & NWQL \\
\hline Potassium, filtered & 0.06 & $\mathrm{mg} / \mathrm{L}$ & American Water Works Association, 1998 & NWQL \\
\hline Silica, filtered & 0.018 & $\mathrm{mg} / \mathrm{L}$ & Fishman, 1993 & NWQL \\
\hline Sodium, filtered & 0.1 & $\mathrm{mg} / \mathrm{L}$ & Fishman, 1993 & NWQL \\
\hline Specific conductance, unfiltered, lab & 5 & $\mu \mathrm{S} / \mathrm{cm}$ & Fishman and Friedman, 1989 & NWQL \\
\hline Strontium, filtered & 0.2 & $\mu \mathrm{g} / \mathrm{L}$ & Fishman, 1993 & NWQL \\
\hline Strontium-87/strontium- 86 ratio, filtered & -- & ratio & Bullen and others, 1996 & MMIL \\
\hline Sulfate, filtered & 0.02 & $\mathrm{mg} / \mathrm{L}$ & Fishman and Friedman, 1989 & NWQL \\
\hline$\delta^{18} \mathrm{O}$ in water, unfiltered & -- & per mil & Révész and Coplen, 2008b & RSIL \\
\hline$\delta \mathrm{D}$ in water, unfiltered & -- & per mil & Révész and Coplen, 2008a & RSIL \\
\hline$\delta^{15}{\mathrm{~N}-\mathrm{NO}_{3}}_{3}$, filtered & -- & per mil & Coplen and others, 2012 & RSIL \\
\hline$\delta^{18} \mathrm{O}-\mathrm{NO}_{3}$, filtered & -- & per mil & Coplen and others, 2012 & RSIL \\
\hline
\end{tabular}


Alkalinity was titrated either in the field or at the USGS South Texas Program Office by the sampling team. Major ions, trace elements, nutrients, pesticides, and pesticide degradates were analyzed at the USGS National Water Quality Laboratory (NWQL) in Denver, Colorado. Measured nutrient species included $\mathrm{NO}_{3}$ plus $\mathrm{NO}_{2}, \mathrm{NO}_{2}, \mathrm{NH}_{4}$ plus dissolved organic $\mathrm{N}$ (DON), orthophosphate (ortho-P), and phosphorus $(\mathrm{P})$. Calculated nutrient species included $\mathrm{NO}_{3}$ (measured $\mathrm{NO}_{3}$ plus $\mathrm{NO}_{2}$ concentration minus the measured $\mathrm{NO}_{2}$ concentration), DON (measured $\mathrm{NH}_{4}$ plus DON concentration minus the measured $\mathrm{NH}_{4}$ concentration), and total dissolved $\mathrm{N}$ (sum of the measured concentrations of $\mathrm{NO}_{3}, \mathrm{NO}_{2}, \mathrm{NH}_{4}$, and DON). Dissolved solids were calculated as the sum of the measured major ions (calcium, magnesium, sodium, potassium, silica, chloride, sulfate, and alkalinity [carbonate/bicarbonate expressed as carbonate equivalent]), plus the sum of all other measured dissolved constituents. Major ions typically make up the bulk of the dissolved constituents in a sample (Hem, 1985). All N species are reported in units of milligrams per liter as $\mathrm{N}$ and discussed as N. Ortho-P is reported in units of milligrams per liter as $\mathrm{P}$ and discussed as $\mathrm{P}$. Results for some pesticides and pesticide degradates were qualified as estimated ("E") by the NWQL under laboratory reporting conventions used during the study period. A remark code of "E" was used when compounds were identified, but concentrations could not be accurately quantified for a variety of reasons (Sandstrom and others, 2001) or when results are greater than the longterm method detection level and less than the laboratory reporting level (LRL) (Childress and others, 1999). The ${ }^{87} \mathrm{Sr} /{ }^{86} \mathrm{Sr}$ samples were analyzed by the USGS Metal and Metalloid Isotope Laboratory in Menlo Park, California. The $\delta^{18} \mathrm{O}, \delta \mathrm{D}, \delta^{15} \mathrm{~N}^{-\mathrm{NO}_{3}}$, and $\delta^{18} \mathrm{O}-\mathrm{NO}_{3}$ samples were analyzed by the USGS Reston Stable Isotope Laboratory (RSIL) in Reston, Virginia.

\section{Quality Assurance for Water Samples}

Quality-assurance (QA) samples including equipment and field blanks, split replicate environmental samples, and environmental pesticide matrix-spike samples were collected and analyzed to evaluate bias and variability of environmental samples. Bias is the systematic error inherent in a method or caused by some artifact of the measurement system. Variability is the extent to which data points in a statistical distribution or dataset diverge from the average (or mean) value, as well as the extent to which these data points differ from each other (Mueller and others, 2015). A total of 75 QA samples were collected from rainfall, surface-water, spring, and groundwater sites and analyzed for major ions, nutrients, trace elements, and pesticide compounds as part of the study during 2013-16. All QA sample results collected in the field during the study are shown in Opsahl and others (2018). QA sample results for water-quality data collected prior to the current study are discussed in Opsahl (2012). In addition to the QA samples submitted from the field, the USGS NWQL analyzed laboratory blanks, replicates, and spikes.

Blank samples test for bias from introduction of contaminants to environmental samples. Two types of blank samples were analyzed in this study: equipment and field. Equipment blanks are used to demonstrate that samplecollection and sample-processing equipment and equipmentcleaning procedures are not sources of contamination. In comparison, field blanks are used to assess contamination from field conditions during sampling. All of the blank samples were collected, processed, and analyzed in the same manner as were the environmental samples. Blanks were collected by using high-purity inorganic-free or organicfree water tested by the USGS NWQL and certified to be less than the LRL for constituent concentrations. A total of 25 blanks (combination of inorganic, organic, equipment, and field) were collected during this study. Eleven equipment blanks (inorganic and [or] organic) were collected from bulk rainfall collectors ( 3 samples), surface-water autosamplers (5 samples), groundwater pump equipment ( 2 samples), and pump hoist truck equipment (1 sample) during 2013-16. Fourteen field blanks (inorganic or organic) were collected from 1 surface-water site ( 2 samples) and 1 groundwater site (12 samples) during 2013-16.

Major ions, including calcium $(\mathrm{Ca})$, potassium $(\mathrm{K})$, chloride $(\mathrm{Cl})$, and fluoride $(\mathrm{F})$, were detected in both the equipment blanks and the field blanks (table 3 ). Ca was a commonly detected constituent, occurring at least once in all equipment blank type and field blank type samples with the exception of the groundwater pump equipment blank sample (table 3 ). The $\mathrm{Ca}$ concentrations detected were relatively consistent, ranging from 0.024 to $0.077 \mathrm{mg} / \mathrm{L}$ for all blank types (table 3). Although Ca was detected in most equipment and field blanks, the concentrations were several orders of magnitude lower than any surface-water or groundwater environmental sample concentrations and were assumed to not substantially bias the sample results for surface-water and groundwater samples. K was only detected in one bulk rainfall equipment blank sample. The concentration of $\mathrm{K}$ in the rainfall equipment blank sample collected from the Urban rainfall site 2 on May 6, 2015, was $0.08 \mathrm{mg} / \mathrm{L}$, lower than the environmental $\mathrm{K}$ concentration of $0.27 \mathrm{mg} / \mathrm{L}$ collected on May 6, 2015 (Opsahl and others, 2018). The environmental $\mathrm{K}$ concentrations in samples from this site likely are representative of environmental concentrations although about a third of the value may be subject to positive bias. Ca was detected in all rainfall equipment blanks at concentrations similar to those measured in rainfall samples; therefore, $\mathrm{Ca}$ concentrations in rainfall samples should be considered as potentially contaminated and results interpreted with caution. 
Table 3. Summary of quality-assurance data for selected compounds detected in equipment blank and field blank water-quality samples collected from sites in the San Antonio segment of the Edwards aquifer, south-central Texas, 2013-16.

[LRL, laboratory reporting level; mg/L, milligram per liter; N, nitrogen; results summarized from Opsahl and others (2018)]

\begin{tabular}{|c|c|c|c|c|c|}
\hline Constituent & $\begin{array}{l}\text { Number of } \\
\text { samples }\end{array}$ & $\begin{array}{c}\text { Number of } \\
\text { samples greater } \\
\text { than LRL }\end{array}$ & LRL & $\begin{array}{c}\text { Minimum sample } \\
\text { concentration } \\
\text { greater than LRL }\end{array}$ & $\begin{array}{c}\text { Maximum sample } \\
\text { concentration } \\
\text { greater than LRL }\end{array}$ \\
\hline \multicolumn{6}{|c|}{ Rainfall equipment blank water-quality samples } \\
\hline Calcium, filtered (mg/L) & 3 & 1 & 0.022 & 0.024 & 0.035 \\
\hline Potassium, filtered (mg/L) & 3 & 1 & 0.03 & 0.08 & 0.08 \\
\hline Chloride, filtered $(\mathrm{mg} / \mathrm{L})$ & 3 & 3 & 0.02 & 0.02 & 0.06 \\
\hline \multicolumn{6}{|c|}{ Surface-water autosampler equipment blank water-quality samples } \\
\hline Calcium, filtered (mg/L) & 3 & 2 & 0.022 & 0.027 & 0.077 \\
\hline Chloride, filtered (mg/L) & 3 & 1 & 0.06 & 0.06 & 0.06 \\
\hline \multicolumn{6}{|c|}{ Groundwater pump equipment blank water-quality samples } \\
\hline \multicolumn{6}{|c|}{ Pump hoist truck equipment blank water-quality sample } \\
\hline Ammonia, filtered (mg/L as N) & 1 & 1 & 0.01 & 0.01 & 0.01 \\
\hline \multicolumn{6}{|c|}{ Surface-water field blank water-quality sample } \\
\hline Chloride, filtered $(\mathrm{mg} / \mathrm{L})$ & 1 & 1 & 0.02 & 0.05 & 0.05 \\
\hline \multicolumn{6}{|c|}{ Groundwater field blank water-quality samples } \\
\hline Calcium, filtered $(\mathrm{mg} / \mathrm{L})$ & 7 & 1 & 0.022 & 0.027 & 0.027 \\
\hline Chloride, filtered (mg/L) & 7 & 1 & 0.02 & 0.03 & 0.03 \\
\hline Fluoride, filtered (mg/L) & 7 & 1 & 0.01 & 0.02 & 0.02 \\
\hline Ammonia, filtered (mg/L as $\mathrm{N})$ & 9 & 1 & 0.01 & 0.02 & 0.02 \\
\hline
\end{tabular}

$\mathrm{Cl}$ was the most commonly detected constituent, occurring in the rainfall equipment, surface-water autosampler, and groundwater pump equipment blank samples, as well as the surface-water field and groundwater field blank samples (table 3 ). The $\mathrm{Cl}$ concentrations detected in the blank samples ranged from 0.02 to $0.07 \mathrm{mg} / \mathrm{L}$, which was much less than the environmental $\mathrm{Cl}$ concentrations for all site types (table 3; Opsahl and others, 2018). Similar to the results for $\mathrm{Ca}$ and $\mathrm{K}$, the $\mathrm{Cl}$ results from the blank samples are low and are not assumed to bias the environmental results.

F was detected in two rainfall equipment blank samples and one groundwater field blank sample (table 3 ). Both rainfall equipment blank samples were collected May 6, 2015, from different rainfall collectors. The concentrations of $\mathrm{F}$ detected in the rainfall equipment blank samples were 0.12 and $0.34 \mathrm{mg} / \mathrm{L}$, which were higher than the associated environmental sample concentrations. Concentrations of less than $(<) 0.01$, E0.03, and $0.2 \mathrm{mg} / \mathrm{L}$ were measured in samples collected from Urban rainfall 2 on May 6, 2015, and from the rainfall collector at the Frio River on May 12, 2015, and May 13, 2015 (Opsahl and others, 2018). The rainfall equipment blank sample F concentrations most likely are an artifact of the sample processing and not environmental $\mathrm{F}$ concentrations. Given the frequency of $\mathrm{F}$ detection in the rainfall equipment blank samples (two of three) and concentrations well above the LRL, all F concentrations for rainfall samples were censored from the dataset and not used in any data analysis. The concentration of $\mathrm{F}$ in the groundwater field blank sample collected from the Mission well on November 14, 2013, was $0.02 \mathrm{mg} / \mathrm{L}$, whereas the environmental $\mathrm{F}$ concentration was $0.29 \mathrm{mg} / \mathrm{L}$ collected from this well on the same date (Opsahl and others, 2018). The environmental sample F results for the Mission well are representative of environmental concentrations. Given that there was only one detection of $\mathrm{F}$ in seven groundwater field blank samples and that sample had a concentration $(0.02 \mathrm{mg} / \mathrm{L})$ very close to the $\mathrm{LRL}(0.01 \mathrm{mg} / \mathrm{L})$, no remaining $\mathrm{F}$ concentration values were censored from the dataset. 
$\mathrm{NH}_{4}$ was detected in the pump hoist truck equipment blank sample collected on December 22, 2014, and the groundwater field blank sample collected on November 12, 2013 (table 3 in Opsahl and others, 2018). The $\mathrm{NH}_{4}$ concentration in the pump hoist truck equipment blank sample was $0.01 \mathrm{mg} / \mathrm{L}$, and the concentration in the groundwater field blank sample was $0.02 \mathrm{mg} / \mathrm{L}$ (table 3). These concentrations were equal to or higher than the concentrations in the associated environmental samples collected from Seco well $(0.01 \mathrm{mg} / \mathrm{L}$ collected on December 23,2014$)$ and Turtle well $(0.01 \mathrm{mg} / \mathrm{L}$ collected on November 12, 2013) (Opsahl and others, 2018), although all concentrations are very low. Given that only 2 among all $20 \mathrm{NH}_{4}$ blank samples in this study had a detection of $\mathrm{NH}_{4}$, no data were censored from the study, although the possibility that low concentrations of $\mathrm{NH}_{4}$ can result from sample processing is acknowledged.

There were no detections of pesticides in any of the equipment and field blank samples (Opsahl and others, 2018). Pesticide concentrations reported from environmental samples are assumed to be unaffected by the introduction of contaminants originating from sample-collection or sampleprocessing methods.

Replicate samples are used to evaluate variability in measurements associated with analytical processes, sampleprocessing protocols, or natural variation and to provide information on the reproducibility and precision of sample processing and analysis. In this study, split replicate samples were used to evaluate sample-processing variability. Precision can be evaluated by comparing concentrations between environmental and replicate sample pairs and expressed as relative percent differences (RPDs). A combination of 42 split replicate samples (21 replicate pairs) were collected and processed from surface-water, spring, and groundwater sites during 2013-16 by following the guidelines listed in the USGS "National Field Manual for the Collection of WaterQuality Data" (U.S. Geological Survey, variously dated) and analyzed for the same constituents used for environmental samples including major ions, nutrients, trace elements, pesticides, stable isotopes of water and $\mathrm{NO}_{3}$, and strontium isotopes (Opsahl and others, 2018).

RPDs were calculated for each replicate pair of constituents having detectable concentrations (summarized in table 4). If one or both analyses in a constituent replicate pair were reported as less than the applicable LRL, then that constituent pair was excluded from the analysis. RPDs were calculated by using the following equation:

$$
\mathrm{RPD}=\left[\left|C_{1}-C_{2}\right| /\left(\left(C_{1}+C_{2}\right) / 2\right)\right] \times 100
$$

where

\footnotetext{
$C_{1}$ is the constituent concentration, in milligrams per liter, from the environmental sample; and

$\mathrm{C}_{2}$ is the constituent concentration, in milligrams per liter, from the replicate sample.
}

RPDs were calculated, and results were separated into surface-water results or groundwater results (table 4). Twentyfour of thirty-one median RPDs calculated for individual constituents from the surface-water replicate samples were less than 10 percent (table 4), indicating good reproducibility for individual constituents between the environmental and replicate surface-water samples. The minimum and maximum RPD results calculated for all constituents from surfacewater replicate samples ranged from 0 to 67 percent, with a median RPD of 2 percent (table 4). In comparison, 24 of 25 median RPDs for individual constituents from the spring and groundwater replicate samples were less than 10 percent (table 4), also indicating good reproducibility. The RPDs calculated for all constituents from groundwater replicate samples ranged from 0 to about 67 percent (table 4), with a median RPD of 1 percent. Overall, results indicate that there was good to excellent reproducibility for most of the constituents. The higher RPDs, generally greater than 20 percent, were associated with replicate pairs that had lower concentrations that were close in value to the LRL (Opsahl and others, 2018). When evaluating RPDs, the magnitude of the concentrations being evaluated needs to be considered. Although the difference between environmental and replicate concentrations may be the same for a given constituent, the difference evaluated relative to the mean concentration of the replicate pair increases as the concentrations being evaluated decrease. Larger RPDs were associated with surface-water replicate pairs that had low concentrations of bromide, $\mathrm{N}$ nutrients $\left(\mathrm{NH}_{4}, \mathrm{NO}_{2}\right.$, organic $\mathrm{N}$, and total $\mathrm{N}$ ), and prometon, as well as for the $\delta^{18} \mathrm{O}$ of water (Opsahl and others, 2018). While the RPDs for replicates with lower concentrations often are large, these values do not necessarily indicate a lack of laboratory precision. The RPDs associated with this study indicated that the sampling and analytical procedures for most constituents were consistent and reproducible.

Field pesticide matrix-spike samples (hereinafter referred to as "pesticide spikes") are used to assess bias and variability from matrix interference or degradation of pesticide constituent concentrations that might occur during sample processing, storage, and analysis. Pesticide spikes are environmental samples to which a known volume and concentration of constituents are added; analytical recoveries of the spiked constituents are expressed as percentages of expected (theoretical) concentrations. Computed field-spike recoveries are compared to theoretical and laboratory recoveries to evaluate matrix interferences or degradation of pesticides.

During 2013-16, pesticide spikes were added to 8 environmental samples collected from rainfall, surfacewater, spring, and groundwater sites by following guidelines listed in the USGS "National Field Manual for the Collection of Water-Quality Data" (U.S. Geological Survey, variously dated) and analyzed for 83 pesticides and pesticide degradates (Opsahl and others, 2018). A spike recovery was calculated 
Table 4. Summary of quality-assurance data of paired environmental and split replicate water-quality samples and associated relative percent difference calculations for water-quality sample pairs collected from surface-water, spring, and groundwater sites in the San Antonio segment of the Edwards aquifer, south-central Texas, 2013-16.

[LRL, laboratory reporting level; RPD, relative percent difference in percent (calculated for replicate pairs with concentrations greater than the minimum detectable concentration); mg/L, milligram per liter; *, calculated constituent; --, no data, value not calculated, or concentrations were less than or equal to the $\mathrm{LRL} ; \mathrm{CaCO}_{3}$, calcium carbonate; $\mathrm{SiO}_{2}$; silicon dioxide; $\mathrm{N}$, nitrogen; $\mathrm{P}$, phosphorus; $\mathrm{NO}_{3}$, nitrate; $\mathrm{NO}_{2}$, nitrite; $\mu \mathrm{g} / \mathrm{L}$, microgram per liter; E, estimated; DEA, deethylatrazine; CIAT, 2-Chloro-4-isopropylamino-6-amino-s-triazine; $\delta \mathrm{D}$, delta deuterium in water; $\delta^{18} \mathrm{O}$, delta oxygen-18 in water; $\delta^{15} \mathrm{~N}-\mathrm{NO}{ }_{3}$, delta nitrogen-15 in nitrate; ${ }^{18} \mathrm{O}-\mathrm{NO}_{3}$, delta oxygen-18 in nitrate; ${ }^{87} \mathrm{Sr}$, strontium-87; ${ }^{86} \mathrm{Sr}$, strontium-86; results summarized from Opsahl and others (2018)]

\begin{tabular}{|c|c|c|c|c|c|c|}
\hline Constituent & LRL & $\begin{array}{l}\text { Number of repli- } \\
\text { cate sets available } \\
\text { to calculate for } \\
\text { surface-water } \\
\text { samples }\end{array}$ & $\begin{array}{c}\text { Number of } \\
\text { replicate sets } \\
\text { greater than LRL } \\
\text { for surface-water } \\
\text { samples }\end{array}$ & $\begin{array}{c}\text { Minimum } \\
\text { surface-water RPD } \\
\text { (percent) }\end{array}$ & $\begin{array}{c}\text { Maximum } \\
\text { surface-water RPD } \\
\text { (percent) }\end{array}$ & $\begin{array}{c}\text { Median } \\
\text { surface-water RPD } \\
\text { (percent) }^{1}\end{array}$ \\
\hline Dissolved solids, filtered, sum of constituents (mg/L)* & -- & 4 & 4 & 1 & 5 & 3 \\
\hline Hardness, filtered $\left(\mathrm{mg} / \mathrm{L}\right.$ as $\left.\mathrm{CaCO}_{3}\right) *$ & -- & 5 & 5 & 1 & 4 & 1 \\
\hline Calcium, filtered (mg/L) & 0.022 & 5 & 5 & 1 & 4 & 2 \\
\hline Magnesium, filtered (mg/L) & 0.011 & 5 & 5 & 1 & 3 & 2 \\
\hline Potassium, filtered (mg/L) & 0.1 & 5 & 5 & 0 & 5 & 3 \\
\hline Sodium, filtered (mg/L) & 0.1 & 5 & 5 & 0 & 4 & 1 \\
\hline Bromide, filtered (mg/L) & 0.01 & 2 & 2 & 2 & 35 & 19 \\
\hline Chloride, filtered (mg/L) & 0.02 & 5 & 5 & 0 & 1 & 0 \\
\hline Fluoride, filtered (mg/L) & 0.01 & 5 & 5 & 0 & 9 & 0 \\
\hline Silica, filtered $\left(\mathrm{mg} / \mathrm{L}\right.$ as $\left.\mathrm{SiO}_{2}\right)$ & 0.018 & 5 & 5 & 1 & 5 & 1 \\
\hline Sulfate, filtered (mg/L) & 0.02 & 5 & 5 & 0 & 0 & 0 \\
\hline Ammonia plus organic nitrogen, filtered (mg/L as $\mathrm{N}$ ) & 0.07 & 9 & 8 & 0 & 46 & 19 \\
\hline Ammonia plus organic nitrogen, unfiltered (mg/L as $\mathrm{N}$ ) & 0.07 & 10 & 10 & 0 & 30 & 11 \\
\hline Ammonia, filtered (mg/L as N) & 0.01 & 11 & 2 & 0 & 67 & 33 \\
\hline Nitrate plus nitrite, filtered (mg/L as N) & 0.01 & 11 & 11 & 0 & 6 & 1 \\
\hline Nitrate, filtered $(\mathrm{mg} / \mathrm{L}$ as $\mathrm{N}) *$ & -- & 11 & 11 & 0 & 4 & 1 \\
\hline Nitrite, filtered (mg/L as N) & 0.001 & 11 & 8 & 0 & 40 & 0 \\
\hline Organic nitrogen, filtered $(\mathrm{mg} / \mathrm{L}$ as $\mathrm{N}) *$ & $0.02-0.18$ & 10 & 1 & 0 & 0 & 0 \\
\hline Organic nitrogen, unfiltered $(\mathrm{mg} / \mathrm{L}$ as $\mathrm{N}) *$ & 0.07 & 10 & 2 & 9 & 31 & 20 \\
\hline Orthophosphate, filtered (mg/L as P) & 0.004 & 5 & 2 & 0 & 0 & 0 \\
\hline Phosphorus, filtered (mg/L as P) & 0.01 & 4 & 0 & -- & -- & -- \\
\hline Phosphorus, unfiltered (mg/L as P) & 0.01 & 4 & 0 & -- & -- & -- \\
\hline $\begin{array}{l}\text { Total nitrogen }\left[\mathrm{NO}_{3}+\mathrm{NO}_{2}+\mathrm{NH}_{3}+\text { organic-N], }\right. \\
\quad \text { filtered }(\mathrm{mg} / \mathrm{L})\end{array}$ & $0.14-1.9$ & 9 & 8 & 0 & 13 & 0 \\
\hline $\begin{array}{l}\text { Total nitrogen }\left[\mathrm{NO}^{3}+\mathrm{NO}_{2}+\mathrm{NH}_{3}+\text { organic-N], }\right. \\
\quad \text { unfiltered }(\mathrm{mg} / \mathrm{L})\end{array}$ & $1.2-2.6$ & 10 & 10 & 0 & 16 & 2 \\
\hline
\end{tabular}




\begin{tabular}{|c|c|c|c|c|c|c|}
\hline Constituent & LRL & $\begin{array}{l}\text { Number of repli- } \\
\text { cate sets available } \\
\text { to calculate for } \\
\text { surface-water } \\
\text { samples }\end{array}$ & $\begin{array}{c}\text { Number of } \\
\text { replicate sets } \\
\text { greater than LRL } \\
\text { for surface-water } \\
\text { samples }\end{array}$ & $\begin{array}{l}\text { Minimum } \\
\text { surface-water RPD } \\
\text { (percent) }\end{array}$ & $\begin{array}{c}\text { Maximum } \\
\text { surface-water RPD } \\
\text { (percent) }\end{array}$ & $\begin{array}{c}\text { Median } \\
\text { surface-water RPD } \\
\text { (percent) }^{1}\end{array}$ \\
\hline Strontium, filtered $(\mu \mathrm{g} / \mathrm{L})$ & 0.2 & 9 & 9 & 0 & 2 & 1 \\
\hline Boron, filtered $(\mu \mathrm{g} / \mathrm{L})$ & 2.0 & 4 & 4 & 0 & 5 & 2 \\
\hline DEA (CIAT), filtered, recoverable ( $\mu \mathrm{g} / \mathrm{L})$ & 0.0 & 2 & 0 & -- & -- & -- \\
\hline Atrazine, filtered, recoverable $(\mu \mathrm{g} / \mathrm{L})$ & 0.008 & 2 & 0 & -- & -- & -- \\
\hline Desulfinyl-fipronil, filtered, recoverable ( $\mu \mathrm{g} / \mathrm{L})$ & 0.012 & 2 & 1 & 0 & 0 & 0 \\
\hline Prometon, filtered, recoverable $(\mu \mathrm{g} / \mathrm{L})$ & 0.012 & 2 & 1 & 15 & 15 & 15 \\
\hline Simazine, filtered, recoverable $(\mu \mathrm{g} / \mathrm{L})$ & 0.006 & 2 & 0 & -- & -- & -- \\
\hline$\delta \mathrm{D}$ in water, unfiltered, per mil & -- & 2 & 2 & 1 & 8 & 4 \\
\hline$\delta^{18} \mathrm{O}$ in water, unfiltered, per mil & -- & 2 & 2 & 4 & 22 & 13 \\
\hline$\delta^{15} \mathrm{~N}-\mathrm{NO}_{3}$, filtered, per mil & -- & 2 & 1 & 2 & 2 & 2 \\
\hline$\delta^{18} \mathrm{O}-\mathrm{NO}_{3}$, filtered, per mil & -- & 2 & 1 & 6 & 6 & 6 \\
\hline${ }^{87} \mathrm{Sr} /{ }^{86} \mathrm{Sr}$, filtered, ratio & -- & 2 & 2 & 0 & 0 & 0 \\
\hline
\end{tabular}


Table 4. Summary of quality-assurance data of paired environmental and split replicate water-quality samples and associated relative percent difference calculations for water-quality sample pairs collected from surface-water, spring, and groundwater sites in the San Antonio segment of the Edwards aquifer, south-central Texas, 2013-16.Continued

[LRL, laboratory reporting level; RPD, relative percent difference in percent (calculated for replicate pairs with concentrations greater than the minimum detectable concentration); mg/L, milligram per liter; *, calculated constituent; --, no data, value not calculated, or concentrations were less than or equal to the $\mathrm{LRL} ; \mathrm{CaCO}_{3}$, calcium carbonate; $\mathrm{SiO}_{2}$; silicon dioxide; $\mathrm{N}$, nitrogen; $\mathrm{P}$, phosphorus; $\mathrm{NO}_{3}$, nitrate; $\mathrm{NO}_{2}$, nitrite; $\mu \mathrm{g} / \mathrm{L}$, microgram per liter; E, estimated; DEA, deethylatrazine; CIAT, 2-Chloro-4-isopropylamino-6-amino-s-triazine; $\delta \mathrm{D}$, delta deuterium in water; $\delta^{18} \mathrm{O}$, delta oxygen-18 in water; $\delta^{15} \mathrm{~N}-\mathrm{NO}{ }_{3}$, delta nitrogen-15 in nitrate; ${ }^{18} \mathrm{O}-\mathrm{NO}_{3}$, delta oxygen-18 in nitrate; ${ }^{87} \mathrm{Sr}$, strontium-87; ${ }^{86} \mathrm{Sr}$, strontium-86; results summarized from Opsahl and others (2018)]

\begin{tabular}{|c|c|c|c|c|c|c|c|}
\hline Constituent & $\begin{array}{c}\text { Median } \\
\text { surface-water } \\
\text { concentration }\end{array}$ & $\begin{array}{c}\text { Number of repli- } \\
\text { cate sets avail- } \\
\text { able to calculate } \\
\text { for groundwater } \\
\text { samples }^{2}\end{array}$ & $\begin{array}{l}\text { Number of } \\
\text { replicate sets } \\
\text { greater than LRL } \\
\text { for groundwater } \\
\text { samples }\end{array}$ & $\begin{array}{c}\text { Minimum } \\
\text { groundwater } \\
\text { RPD } \\
\text { (percent) }\end{array}$ & $\begin{array}{c}\text { Maximum } \\
\text { groundwater } \\
\text { RPD } \\
\text { (percent) }\end{array}$ & $\begin{array}{c}\text { Median } \\
\text { groundwater } \\
\text { RPD } \\
\text { (percent) }^{2}\end{array}$ & $\begin{array}{c}\text { Median } \\
\text { groundwater } \\
\text { concentration }\end{array}$ \\
\hline Dissolved solids, filtered, sum of constituents (mg/L)* & 256 & 8 & 8 & 0 & 2 & 0 & 344 \\
\hline Hardness, filtered $\left(\mathrm{mg} / \mathrm{L}\right.$ as $\left.\mathrm{CaCO}_{3}\right) *$ & 235 & 8 & 8 & 0 & 6 & 1 & 306 \\
\hline Calcium, filtered (mg/L) & 63.55 & 8 & 8 & 0 & 8 & 1 & 103.5 \\
\hline Magnesium, filtered (mg/L) & 17.55 & 8 & 8 & 0 & 2 & 1 & 13.05 \\
\hline Potassium, filtered (mg/L) & 1 & 8 & 8 & 1 & 12 & 2 & 1.32 \\
\hline Sodium, filtered (mg/L) & 8.76 & 8 & 8 & 0 & 5 & 2 & 10.15 \\
\hline Bromide, filtered (mg/L) & 0.1 & 8 & 8 & 0 & 5 & 1 & 0.08 \\
\hline Chloride, filtered (mg/L) & 13.2 & 8 & 8 & 0 & 1 & 0 & 17.1 \\
\hline Fluoride, filtered (mg/L) & 0.13 & 8 & 8 & 0 & 11 & 0 & 0.16 \\
\hline Silica, filtered $\left(\mathrm{mg} / \mathrm{L}\right.$ as $\left.\mathrm{SiO}_{2}\right)$ & 12.3 & 8 & 8 & 0 & 7 & 0 & 12.2 \\
\hline Sulfate, filtered (mg/L) & 35.8 & 8 & 8 & 0 & 1 & 0 & 20.4 \\
\hline Ammonia plus organic nitrogen, filtered (mg/L as $\mathrm{N})$ & 0.14 & 2 & 0 & -- & -- & -- & -- \\
\hline Ammonia plus organic nitrogen, unfiltered (mg/L as $\mathrm{N})$ & 0.17 & 4 & 0 & -- & -- & -- & -- \\
\hline Ammonia, filtered (mg/L as $\mathrm{N})$ & 0.01 & 8 & 0 & -- & -- & -- & -- \\
\hline Nitrate plus nitrite, filtered (mg/L as N) & 1.05 & 9 & 9 & 0 & 3 & 1 & 1.9 \\
\hline Nitrate, filtered $(\mathrm{mg} / \mathrm{L} \text { as } \mathrm{N})^{*}$ & 1.05 & 8 & 8 & 0 & 0 & 1 & 1.88 \\
\hline Nitrite, filtered (mg/L as $\mathrm{N})$ & 0.004 & 8 & 0 & -- & -- & -- & -- \\
\hline Organic nitrogen, filtered $(\mathrm{mg} / \mathrm{L} \text { as } \mathrm{N})^{*}$ & 0.13 & 5 & 0 & -- & -- & -- & -- \\
\hline Organic nitrogen, unfiltered $(\mathrm{mg} / \mathrm{L} \text { as } \mathrm{N})^{*}$ & 0.12 & 4 & 0 & -- & -- & -- & -- \\
\hline Orthophosphate, filtered (mg/L as P) & 0.005 & 8 & 8 & 0 & 13 & 0 & 0.010 \\
\hline Phosphorus, filtered (mg/L as P) & -- & 4 & 0 & -- & -- & -- & -- \\
\hline Phosphorus, unfiltered (mg/L as $\mathrm{P}$ ) & -- & 4 & 2 & 0 & 67 & 33 & 0.02 \\
\hline $\begin{array}{l}\text { Total nitrogen }\left[\mathrm{NO}_{3}+\mathrm{NO}_{2}+\mathrm{NH}_{3}+\text { organic-N], }\right. \\
\quad \text { filtered }(\mathrm{mg} / \mathrm{L})\end{array}$ & 1.65 & 2 & 0 & -- & -- & -- & -- \\
\hline $\begin{array}{l}\text { Total nitrogen }\left[\mathrm{NO}^{3}+\mathrm{NO}_{2}+\mathrm{NH}_{3}+\text { organic-N], }\right. \\
\quad \text { unfiltered }(\mathrm{mg} / \mathrm{L})\end{array}$ & 1.35 & 4 & 0 & -- & -- & -- & -- \\
\hline
\end{tabular}




\begin{tabular}{|c|c|c|c|c|c|c|c|}
\hline Constituent & $\begin{array}{c}\text { Median } \\
\text { surface-water } \\
\text { concentration }\end{array}$ & $\begin{array}{c}\text { Number of repli- } \\
\text { cate sets avail- } \\
\text { able to calculate } \\
\text { for groundwater } \\
\text { samples }^{2}\end{array}$ & $\begin{array}{l}\text { Number of } \\
\text { replicate sets } \\
\text { greater than LRL } \\
\text { for groundwater } \\
\text { samples }\end{array}$ & $\begin{array}{l}\text { Minimum } \\
\text { groundwater } \\
\text { RPD } \\
\text { (percent) }\end{array}$ & $\begin{array}{c}\text { Maximum } \\
\text { groundwater } \\
\text { RPD } \\
\text { (percent) }\end{array}$ & $\begin{array}{c}\text { Median } \\
\text { groundwater } \\
\text { RPD } \\
\text { (percent) }^{2}\end{array}$ & $\begin{array}{c}\text { Median } \\
\text { groundwater } \\
\text { concentration }\end{array}$ \\
\hline Strontium, filtered $(\mu \mathrm{g} / \mathrm{L})$ & 395 & 4 & 4 & 1 & 3 & 1 & 409 \\
\hline Boron, filtered $(\mu \mathrm{g} / \mathrm{L})$ & 62.0 & 8 & 8 & 0 & 3 & 2 & 52 \\
\hline DEA (CIAT), filtered, recoverable $(\mu \mathrm{g} / \mathrm{L})$ & E0.009 & 4 & 2 & 0 & 5 & 2 & E0.016 \\
\hline Atrazine, filtered, recoverable $(\mu \mathrm{g} / \mathrm{L})$ & -- & 4 & 2 & 0 & 0 & 0 & 0.01 \\
\hline Desulfinyl-fipronil, filtered, recoverable $(\mu \mathrm{g} / \mathrm{L})$ & 0.002 & 4 & 0 & -- & -- & -- & -- \\
\hline Prometon, filtered, recoverable $(\mu \mathrm{g} / \mathrm{L})$ & 0.021 & 4 & 0 & -- & -- & -- & -- \\
\hline Simazine, filtered, recoverable $(\mu \mathrm{g} / \mathrm{L})$ & -- & 4 & 3 & 0 & 0 & 0 & 0.005 \\
\hline$\delta \mathrm{D}$ in water, unfiltered, per mil & -14.85 & 4 & 4 & 0 & 2 & 1 & -22.9 \\
\hline$\delta^{18} \mathrm{O}$ in water, unfiltered, per mil & -1.93 & 4 & 4 & 0 & 2 & 1 & -4.12 \\
\hline$\delta^{15} \mathrm{~N}^{-\mathrm{NO}_{3}}$, filtered, per mil & 6.28 & 4 & 4 & 0 & 3 & 3 & 7.37 \\
\hline$\delta^{18} \mathrm{O}-\mathrm{NO}_{3}$, filtered, per mil & 2.15 & 4 & 4 & 2 & 7 & 6 & 5.12 \\
\hline${ }^{87} \mathrm{Sr} /{ }^{86} \mathrm{Sr}$, filtered, ratio & 0.70773 & 6 & 6 & 0 & 0 & 0 & 0.70797 \\
\hline
\end{tabular}

${ }^{1}$ Relative percent differences were not calculated when estimated concentrations (E) were reported for one or both replicate samples.

${ }^{2}$ Samples from the Comal 1 spring site at Comal Springs (fig. 1) were for the purpose of this report considered groundwater samples representative of deeper, confined groundwater. 
for constituents with environmental concentrations greater than the LRL. For each constituent with a censored value (value less than the LRL) in the environmental sample, a range of spike recovery was calculated by using zero ( 0 ) for the lowest possible concentration and the LRL for the specified constituent for the highest possible concentration. An average recovery for censored values less than the LRL then was computed by using the low recovery and the high recovery values. Negative values for minimum percent recovery are possible when the measured result of the spike sample is less than the LRL. The percent recovery of the spiked pesticide concentrations was calculated by using the following equations:

$$
\text { Percent recovery }=\left(\left[C_{\mathrm{s}}-C_{\mathrm{u}}\right] \times 100\right) /\left(C_{\text {expd }}\right)
$$

where

$$
\begin{aligned}
& C_{\mathrm{s}} \quad \text { is the measured result of the spiked sample, } \\
& \text { in micrograms per liter, from the } \\
& \text { environmental sample; } \\
& C_{\mathrm{u}} \quad \text { is the measured result of the unspiked } \\
& \text { sample, in micrograms per liter, from the } \\
& \text { environmental sample; and } \\
& C_{\text {expd }} \quad \text { is the expected or theoretical concentration } \\
& \text { added to the spiked sample, in micrograms } \\
& \text { per liter, which is calculated by using the } \\
& \text { following equation: } \\
& C_{\text {expd }}=\left(C_{\text {sol }} \times V_{\text {spike }}\right) /\left(V_{\text {sampl }}\right) \\
& C_{\text {sol }} \text { is the concentration of spike solution, in } \\
& \text { micrograms per liter; } \\
& \mathrm{V}_{\text {spike }} \quad \text { is the amount of spike added, in milliliters; and } \\
& \mathrm{V}_{\text {sampl }} \text { is the spiked sample volume, in liters. }
\end{aligned}
$$

where

Minimum, maximum, and median percent recoveries of each compound were computed for surface-water, spring, and groundwater sites and also individually for the single rainfall sample (Opsahl and others, 2018). Spike recoveries higher than 100 percent and outside the control limits of the laboratory indicate a positive bias for a particular constituent; the actual concentrations probably are lower than the reported concentrations. Pesticide spike recoveries lower than 100 percent indicate a negative bias for a particular constituent; the actual concentrations probably are higher than the reported concentrations for the specified constituent. Pesticide spike recoveries in the range of $85-115$ percent generally indicate that the reported environmental pesticide concentration is a close approximation of the actual pesticide concentration and not greatly affected by matrix influence or degradation.

Overall, the single rainfall pesticide spike sample had the best recovery for all constituents (median $=87$ percent; $n=1$ ) as compared to surface-water spike samples (median $=65$ percent; $\mathrm{n}=3$ ) and spring and groundwater samples (median $=68$ percent; $n=4)($ Opsahl and others, 2018). The most commonly detected pesticides in environmental samples collected during 2013-16 were atrazine, DEA, prometon, and simazine. Pesticide spike recoveries for atrazine were highest in the rainfall spike sample (95 percent) and the surface-water spike samples (minimum RPD $=70$ percent; maximum RPD = 102 percent; median RPD $=90$ percent; $n=3$ ) and lowest in the spring and groundwater spike samples (minimum RPD $=76$ percent; maximum $\mathrm{RPD}=96$ percent; median $\mathrm{RPD}=83$ percent). These spike recoveries indicate that the reported concentrations of atrazine in the rainfall samples are close in value to the actual concentrations of atrazine, whereas the reported concentrations of atrazine in surface-water, spring, and groundwater samples possibly are less than the actual concentrations. Percent recovery of DEA in rainfall samples was 71 percent (Opsahl and others, 2018). Lower DEA recoveries were observed in the surfacewater samples (minimum RPD $=49$ percent; maximum RPD $=78$ percent; median $\mathrm{RPD}=59$ percent $)$ and the spring and groundwater samples (minimum RPD $=49$ percent; maximum $\mathrm{RPD}=63$ percent; median $\mathrm{RPD}=61$ percent). Consistent with results from Martin and others (2009), reported concentrations of DEA are possibly lower than the actual concentrations. Percent recovery of prometon in rainfall samples was about 60 percent. Similar prometon recoveries were observed in the surfacewater samples (minimum RPD = 62 percent; maximum RPD $=74$ percent; median RPD $=66$ percent $)$ and the spring and groundwater samples (minimum RPD $=42$ percent; maximum $\mathrm{RPD}=77$ percent; median $\mathrm{RPD}=60$ percent). These results indicate that reported concentrations of prometon are possibly lower than the actual concentrations. Median percent recovery of simazine in rainfall samples was about 103 percent. Lower simazine recoveries were observed in the surface-water samples (minimum $\mathrm{RPD}=81$ percent; maximum $\mathrm{RPD}=110$ percent; median $\mathrm{RPD}=83$ percent) and the spring and groundwater samples (minimum RPD $=74$ percent; maximum $\mathrm{RPD}=85$ percent; median RPD $=78$ percent). The percent recoveries for simazine in surface-water and spring and groundwater samples indicate that the reported concentrations are possibly lower than the actual concentrations.

\section{Climate Conditions}

The study area is generally prone to climatic and hydrologic extremes (Griffiths and Strauss, 1985; Jones, 1991). The climatic and hydrologic conditions during the study period varied considerably (fig. 3). The study began in July 2013, when the region was undergoing drought conditions. From July 2013 through October 2014, rainfall in the study area was generally low and generally consistent with drought conditions. The Palmer Drought Severity Index (PDSI) is an index calculated from climatological data that is used to estimate dryness associated with drought conditions; the PDSI is particularly useful for estimating cumulative effects over monthly time scales (National Oceanic and Atmospheric Administration, 2017c). Indicators of climatic and hydrologic 

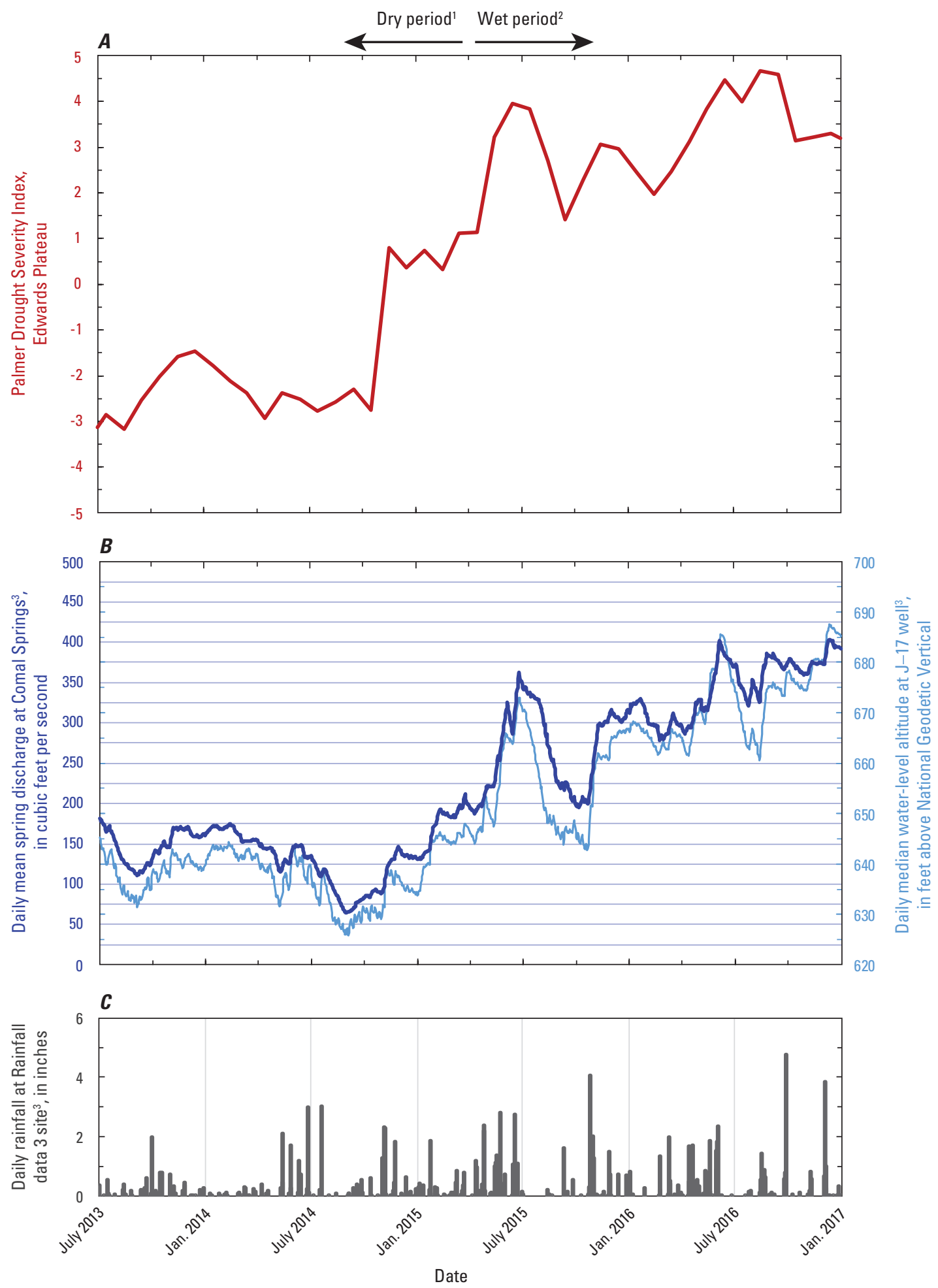

July 2013 through May 2015 is referred to as the "dry period."

2June 2015 through December 2016 is referred to as the "wet period."

${ }^{3}$ Short name (fig. 1; table 1).

Figure 3. Time series (July 2013-December 2016) of $A$, Palmer Drought Severity Index for the Texas Edwards Plateau (National Oceanic and Atmospheric Administration, 2017c); $B$, spring discharge for Comal Springs (U.S. Geological Survey, 2017) and water-level altitude for J-17 well (Edwards Aquifer Authority, 2017b); and $C$, daily rainfall recorded at Rainfall data 3 (National Oceanic and Atmospheric Administration, 2017d). 
conditions including spring discharge at Comal Springs and the WLA at J-17 well were consistent with the PDSI, indicating that drought conditions and relatively little aquifer recharge were occurring during the early part of the study. In November 2014 and again in April and May 2015, widespread rains fell regionally including in the contributing zone and recharge zone of the aquifer. Substantial changes followed over several months, including an increased spring discharge, a rise in WLA at J-17 well, and a shift in the PDSI to normal and then moist conditions. Relatively dry conditions in summer and fall 2015 were accompanied by a moderate decline in the PDSI, J-17 well WLAs, and Comal Springs discharge, but not a return to drought conditions. Winter rains in late 2015 and early 2016 initiated another prolonged rise in the PDSI, J-17 well WLAs, and Comal Springs discharge. In May and June 2016 heavy rains contributed further to this prolonged period of active aquifer recharge. At the conclusion of the study in December 2016, the WLA at J-17 well had risen about $61.6 \mathrm{ft}$ from its lowest point on September 3, 2014 (WLA $=625.9 \mathrm{ft}$ ), to its highest point on December 11, $2016(\mathrm{WLA}=687.5 \mathrm{ft})$. The determination of dry and wet periods was based not only on the PDSI but also on hydrologic conditions including WLAs at J-17 well and Comal Springs discharge. For purposes of this report, the period between July 2013 and May 2015 is referred to as the "dry period," and June 2015 through December 2016 is referred to as the "wet period" (fig. 3).

\section{Hydrologic Conditions}

\section{Surface Water}

The Frio River, a stream that flows across the western rural portion of the recharge zone, has streamflow that is usually sustained by spring discharge, making this site the most amenable of the study's surface-water sites to continuous monitoring. Streamflow patterns and water-quality samplecollection dates for the Frio River showed long periods of base flow that were interrupted by rapid streamflow increases following rainfall and runoff in the contributing zone (fig. 4). Daily median streamflow in the Frio River was at base flow (less than 40 cubic feet per second [ $\left.\mathrm{ft}^{3} / \mathrm{s}\right]$ ) at the onset of the study and remained at base flow until May 2014. The largest storm during the study occurred in May 2015, resulting in a daily median streamflow reaching greater than $7,100 \mathrm{ft}^{3} / \mathrm{s}$. SC values during base flow ranged from about 420 to 520 microsiemens per centimeter at 25 degrees Celsius. During stormwater-runoff events, $\mathrm{SC}$ values decreased in response to storm pulses that were dominated by runoff from recent rainfall. During some stormwater-runoff events (for example, July 2014), however, a pulse of relatively high $\mathrm{SC}$ water occurred as the stormwater-runoff peak receded. Identifying the source of this higher SC was not in the scope of this study, though it might represent a flush from the shallow aquifer of higher conductance water that had accumulated between storm events.
Frio River (fig. 1; table 1)

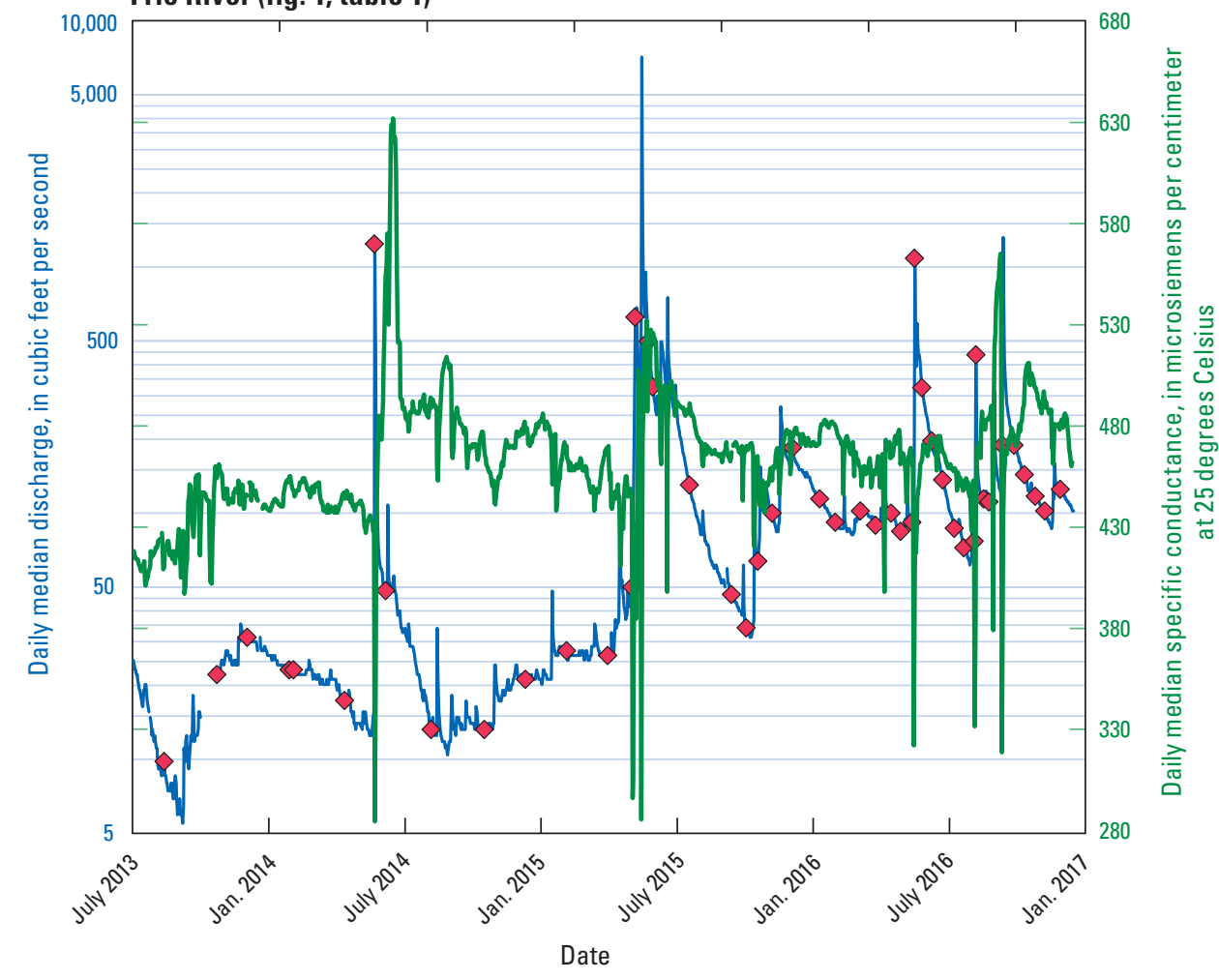

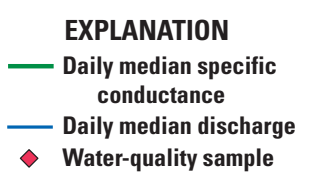

Figure 4. Daily median discharge, specific conductance, and sample-collection dates at Frio River (station 0819500), San Antonio segment of the Edwards aquifer, south-central Texas, July 2013-December 2016. 


\section{Groundwater}

Continuous WLA and SC data collected at the different groundwater sites showed different responses to regional climatic and hydrologic conditions that appeared to vary on the basis of individual site properties (fig. 5A-G). WLA in the wells and discharge at Comal Springs all had notable increases following the transition from the dry to wet period. Among the three unconfined wells (Seco, Parkwood, and Shavano wells), Parkwood and Shavano wells were more immediately responsive to recharge events relative to the deeper Seco well. Similarly, in comparison to Seco well, SC at Parkwood and Shavano wells changed substantially in concert with changes in WLA in response to recharge events. These results suggest that dilute surface-water recharge more directly affects WLA and water chemistry at Parkwood and Shavano wells relative to Seco well. SC at Seco well was notably lower than at Parkwood or Shavano wells, indicating more dilute recharge sources. Over the entire period of study, the patterns of change in WLA at the unconfined wells were similar, although the net change at Shavano well (about $41 \mathrm{ft}$ ) was less than at Seco (about $48 \mathrm{ft}$ ) and Parkwood (about $52 \mathrm{ft}$ ) wells.

Turtle and Mission wells are relatively deep confined wells located downgradient of the unconfined zone and the unconfined wells (fig. 1). WLA was not measured at Turtle and Mission wells because Turtle well was in use as a production well and the Mission well is artesian.

Alternatively, WLA at J-17 well (fig. 3), which is used to represent regional hydrologic conditions, is hereinafter used to provide context for Turtle and Mission wells (fig. $5 E$, $F)$ and to facilitate comparisons with other sites. Among the three confined wells (fig. 5D-F), little change in SC occurred relative to the unconfined wells (fig. $5 A-C$ ), regardless of hydrologic conditions. Somewhat larger fluctuations of SC occurred at the Mission well, although these changes do not generally occur relative to changes in hydrologic conditions. The Mission well is located very near the freshwater/saline-water interface (fig. 1) in a well field of multiple wells; the changes in SC at the Mission well are hypothesized to reflect mixing with small and variable amounts of downdip saline water in response to well-field dynamics or other unknown factors as discussed by Musgrove and others (2010). Similar to the deeper, confined wells, Comal 1 spring showed relatively small changes in SC over the study period (fig. $5 G$ ). The general lack of variability in $\mathrm{SC}$ at the confined groundwater sites indicates that individual recharge events do not directly affect water chemistry at these sites, even with their large changes in WLA (or discharge for Comal 1 spring) in response to changes in hydrologic conditions. It is likely that flow paths to these wells are sufficiently long for mixing processes to homogenize groundwater chemistry.

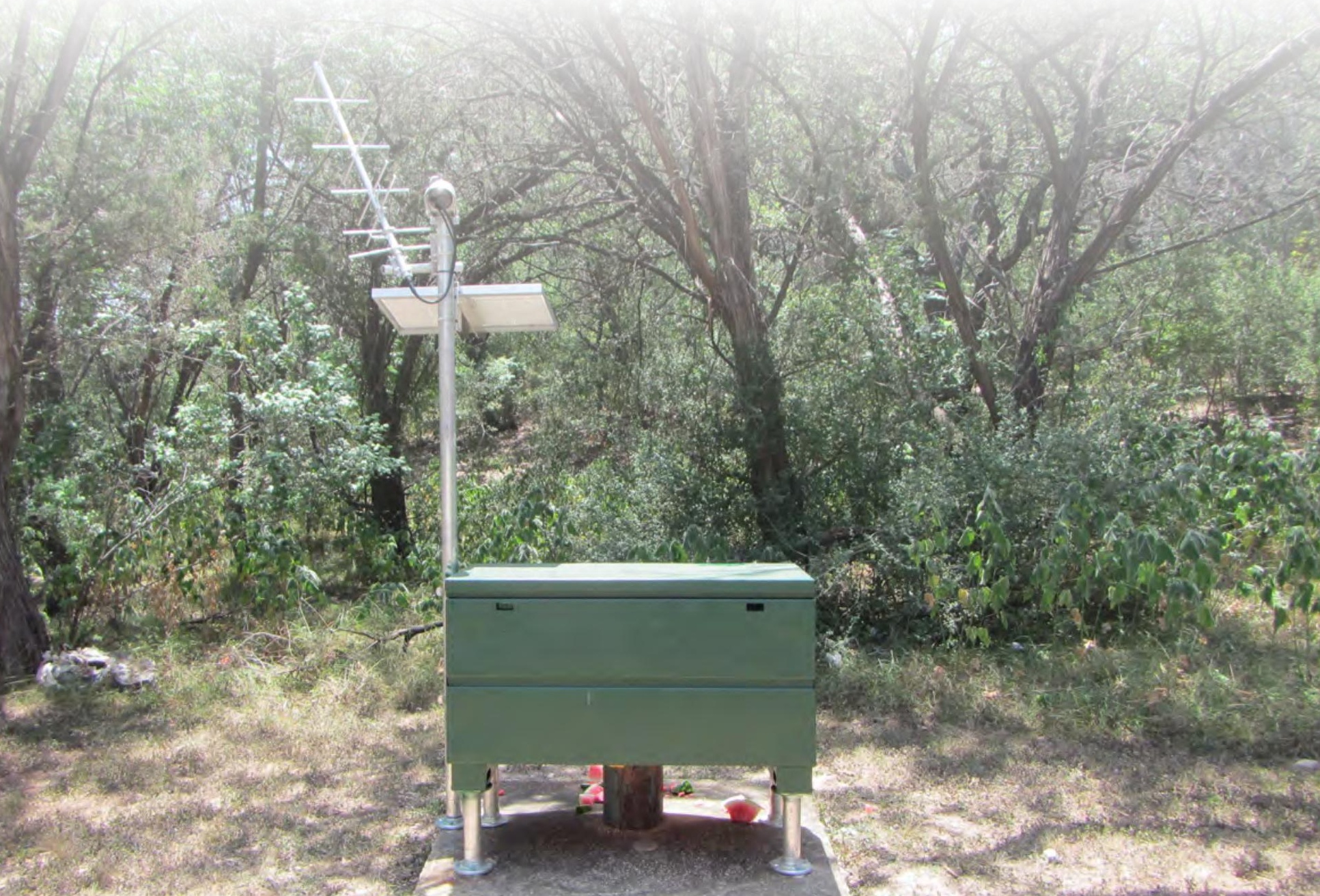



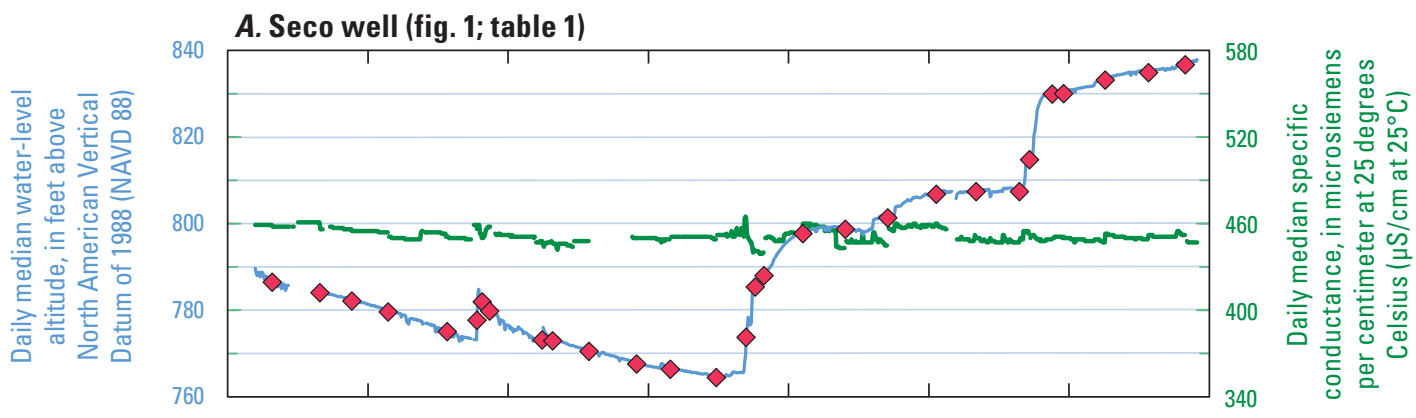

EXPLANATION

- Daily median specific conductance

— Daily median water-level altitude

$\diamond$ Water-quality sample

\section{B. Parkwood well (fig. 1; table 1)}
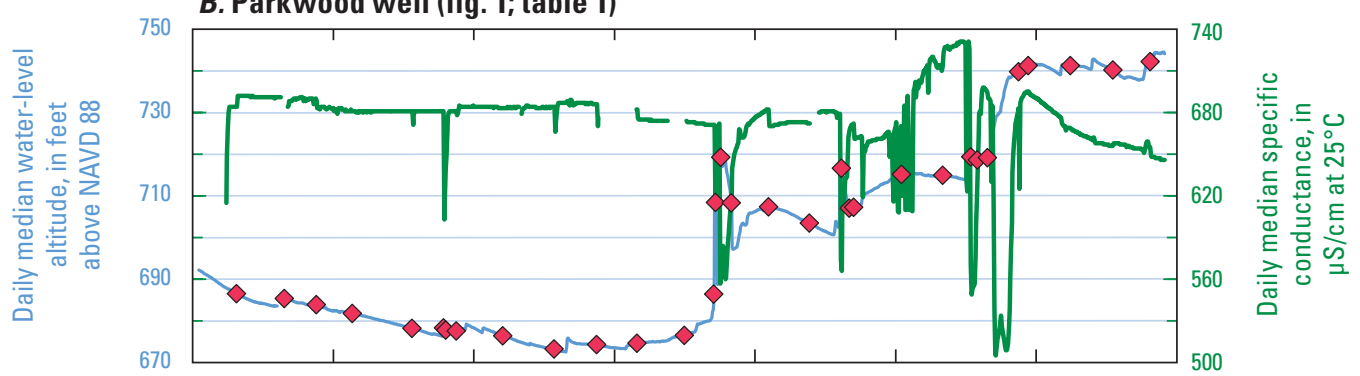

\section{EXPLANATION}

- Daily median specific conductance

Daily median

water-level altitude

$\diamond$ Water-quality sample

\section{Shavano well (fig. 1; table 1)}
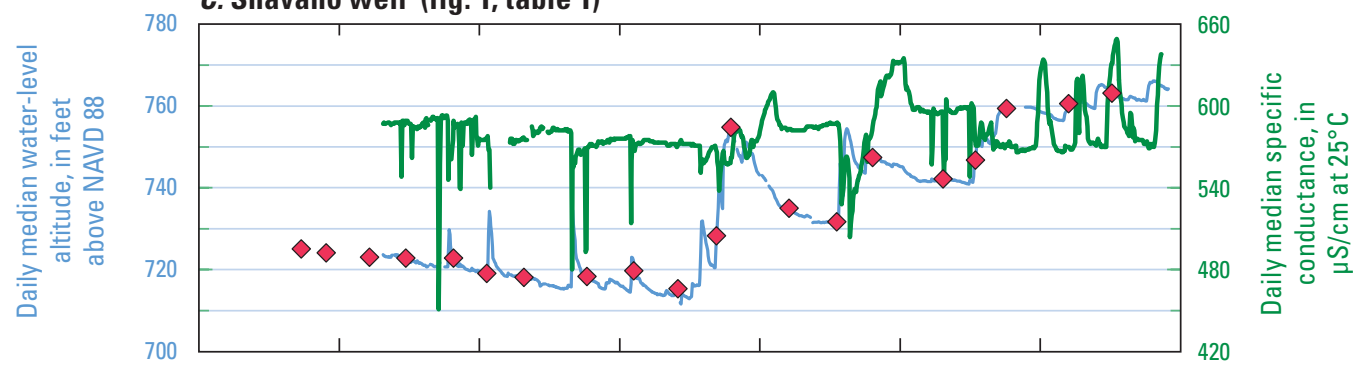

EXPLANATION

- Daily median specific conductance

— Daily median water-level altitude

$\diamond$ Water-quality sample

D. Zarzamora well (fig. 1; table 1)

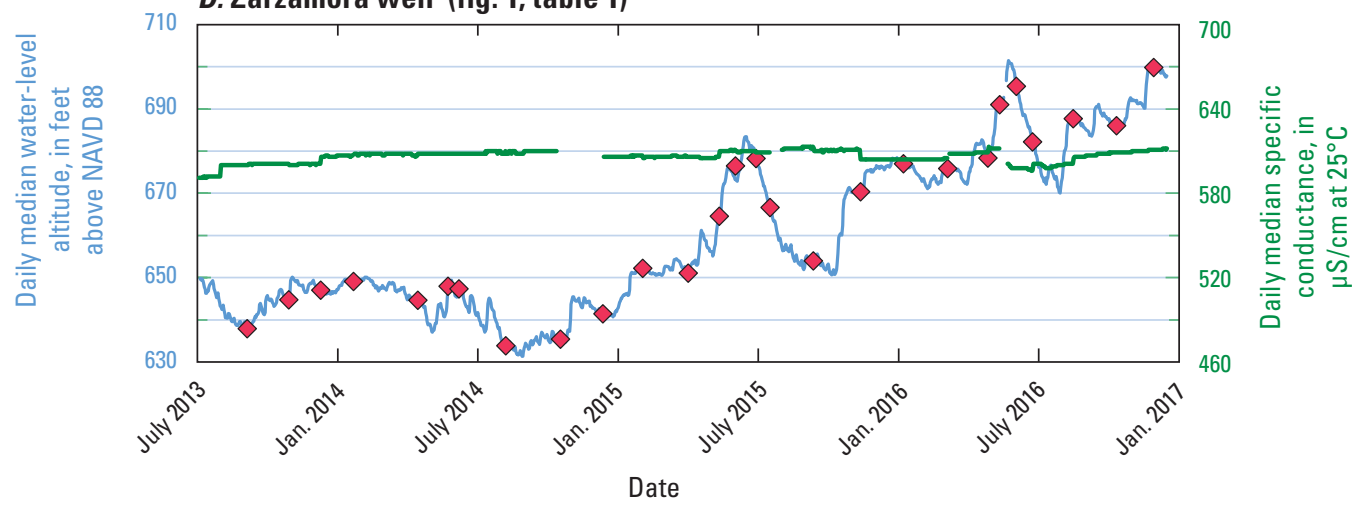

EXPLANATION

— Daily median specific conductance

Daily median water-level altitude

$\diamond$ Water-quality sample

Figure 5. Water-level altitude, specific conductance, and sample-collection times at $A$, Seco Well, $B$, Parkwood well, $C$, Shavano well, $D$, Zarzamora well, $E$, Turtle well, F, Mission well, and G, Comal 1 spring in the San Antonio segment of the Edwards aquifer, southcentral Texas, July 2013-December 2016. Water-level altitude at J-17 well was used to represent regional hydrologic conditions for Turtle and Mission wells ( $E$ and $F$, respectively). 
E. Turtle well' (fig. 1; table 1)

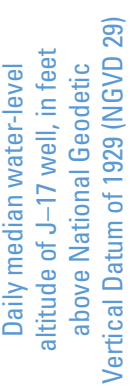

620

\section{F. Mission well² (fig. 1; table 1)}
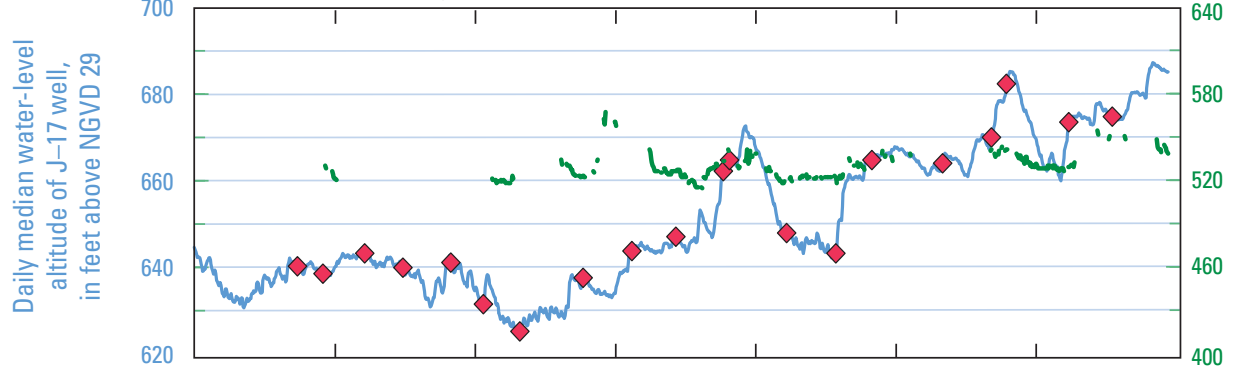

G. Comal 1 spring $^{3}$ (fig. 1; table 1)

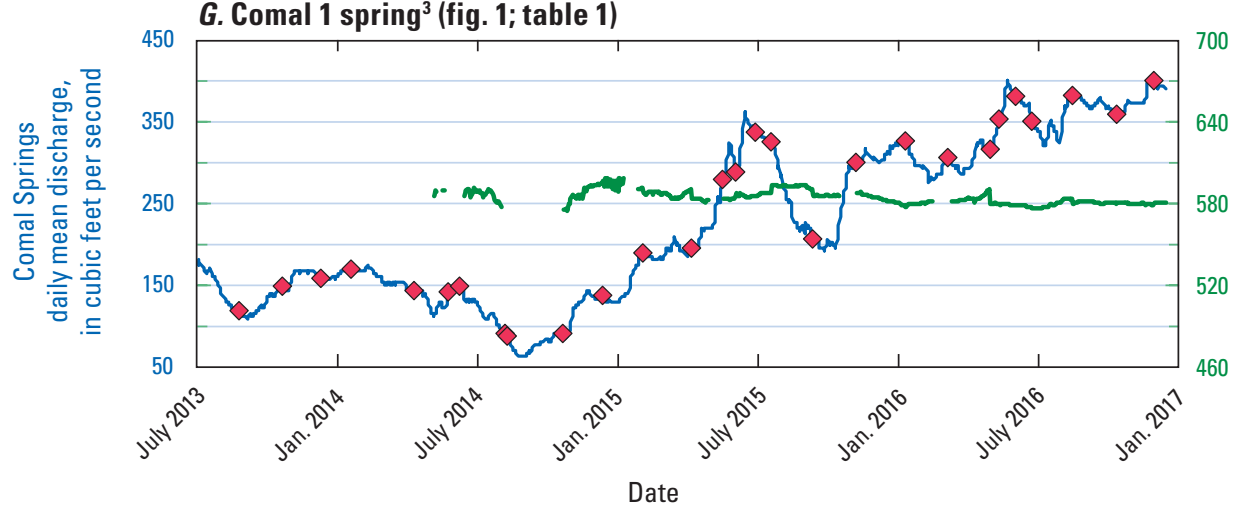

1Daily median specific conductance is for Turtle well. Daily median water-level altitude is for $\mathrm{J}-17$ well (fig. 1; table 1).

${ }^{2}$ Daily median specific conductance is for Mission well. Daily median water-level altitude is for $\mathrm{J}-17$ well (fig. 1; table 1).

${ }^{3}$ Daily median specific conductance is for Comal 1 spring. Daily mean spring discharge is for Comal Springs (fig. 1; table 1).

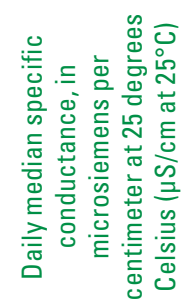

EXPLANATION

Daily median specific conductance

- Daily median

water-level altitude

$\checkmark$ Water-quality sample
EXPLANATION

- Daily median specific conductance

_- Daily median

water-level altitude

$\diamond$ Water-quality sample

Figure 5. Water-level altitude, specific conductance, and sample-collection times at $A$, Seco Well, $B$, Parkwood well, $C$, Shavano well, $D$, Zarzamora well, $E$, Turtle well, $F$, Mission well, and $G$, Comal 1 spring in the San Antonio segment of the Edwards aquifer, southcentral Texas, July 2013-December 2016. Water-level altitude at J-17 well was used to represent regional hydrologic conditions for Turtle and Mission wells ( $E$ and $F$, respectively).-Continued 


\section{Geochemical Conditions}

\section{Meteoric Water Line}

Stable isotopes of hydrogen $(\delta \mathrm{D})$ and oxygen $\left(\delta^{18} \mathrm{O}\right)$ are commonly used in studies of hydrologic processes to provide insight into numerous factors such as groundwater origin and recharge sources, mixing processes, evaporation, and response of karst systems to storms (Craig, 1961; Gat, 1981; Lakey and Krothe, 1996; Jones and others, 2000; Desmarais and Rojstaczer, 2002; Maloszewski and others, 2002). $\delta \mathrm{D}$ and $\delta^{18} \mathrm{O}$ values for all samples collected during this study (rainfall, surface water, and groundwater) have a large range, from -67.5 to -1.4 per mil and -9.87 to -1.15 per mil, respectively (fig. $6 A, B, C$ ). The large range in values is primarily accounted for by differences in rainfall samples (fig. $6 A$ ) and surface-water samples (fig. $6 B$ ); groundwater samples have a much narrower range of isotopic values (fig. $6 C, D$ ). A comparison of $\delta \mathrm{D}$ and $\delta^{18} \mathrm{O}$ data with the global meteoric water line (GMWL) (fig. 6D), which represents the relation for the isotopic composition of rainfall around the globe (Craig, 1961), and a local meteoric water line (LMWL) (Pape and others, 2010) indicates that all samples are meteoric in origin. The meteoric signature for groundwater samples indicates that recharging surface water and groundwater are not affected by processes such as evaporation or extensive water-rock interaction that would offset samples from the GMWL or LMWL.

Variability of $\delta \mathrm{D}$ and $\delta^{18} \mathrm{O}$ values among rainfall, surfacewater, and groundwater samples can provide insight into the susceptibility of different zones of the aquifer to inputs of nutrients and pesticides. A narrower range of $\delta \mathrm{D}$ and $\delta^{18} \mathrm{O}$ values was measured for groundwater (fig. $6 C$ ) relative to rainfall (fig. $6 A$ ) and recharging surface water (fig. $6 B$ ), consistent with mixing and homogenization of recharge within the aquifer. The $\delta \mathrm{D}$ and $\delta^{18} \mathrm{O}$ values from the deeper, confined wells (Zarzamora, Turtle, and Mission wells) cluster tightly around median groundwater $\delta \mathrm{D}$ and $\delta^{18} \mathrm{O}$ values of -23.3 and -4.17 per mil, respectively (fig. $6 D$ ). $\delta \mathrm{D}$ and $\delta^{18} \mathrm{O}$ values measured in samples from the shallow, unconfined wells are more variable than those from the deeper, confined wells (fig. $6 D$ ). The narrower range of $\delta \mathrm{D}$ and $\delta^{18} \mathrm{O}$ values measured for the confined groundwater samples relative to the range of $\delta \mathrm{D}$ and $\delta^{18} \mathrm{O}$ measured for the unconfined groundwater samples is consistent with the characterization of confined groundwater as a deeper well-mixed, homogeneous endmember in the aquifer (Musgrove and others, 2010). Several samples from the unconfined recharge zone wells (specifically, those collected from Shavano and Parkwood wells) have lower stable-isotope values relative to most of the groundwater samples (fig. $6 D$ ). The samples with relatively low isotope values were usually collected at recharge zone wells during wet conditions, often following a recharge event. Rainfall, and corresponding recharge, associated with tropical cyclonic storms has been shown to have isotopically lower stable-isotope values (Lawrence and Gedzelman, 1996; Lawrence, 1998). Additionally, rainfall amount has been shown to be an important control on stable-isotope values for rainfall in central Texas, with lower isotopic values generally associated with increasing rain amounts (Pape and others, 2010). Thus, the isotopic composition of samples with lower isotope values from unconfined wells is consistent with mixing of ambient groundwater with a component derived from a recent, isotopically light recharge source and provides evidence that such areas are more susceptible to contamination and would be more vulnerable if a source of a compound of concern is present.

\section{Water-Rock Interaction}

Geochemical evolution processes that occur as a result of interaction between water and rock in carbonate aquifers also provide insight into groundwater residence time, flow paths, diffuse and conduit recharge sources, mineral-solution reactions, and mixing (Moore and others, 2009; Musgrove and others, 2010). Magnesium $(\mathrm{Mg}) / \mathrm{Ca}$ and $\mathrm{Sr} / \mathrm{Ca}$ ratios in carbonate groundwater typically increase along flow paths as a result of progressive water-rock interaction (Plummer, 1977; Trudgill and others, 1980; Lohmann, 1988; Fairchild and others, 2000; Musgrove and Banner, 2004) ${ }^{87} \mathrm{Sr} /{ }^{86} \mathrm{Sr}$ values in the Edwards aquifer generally decrease with increasing amounts of water-rock interaction, approaching values similar to those of the Cretaceous-age limestone rocks, which have ${ }^{87} \mathrm{Sr} r{ }^{86} \mathrm{Sr}$ values ranging from 0.7074 to 0.7077 (Koepnick and others, 1985; Oetting and others, 1996). Longer groundwater residence times provide increased opportunity for mineralsolution reactions in Edwards aquifer groundwater that tend to result in higher $\mathrm{Mg} / \mathrm{Ca}$ and $\mathrm{Sr} / \mathrm{Ca}$ ratios and lower $\mathrm{Sr}$ isotope compositions.

The relation between $\mathrm{Sr}$ isotopes and $\mathrm{Mg} / \mathrm{Ca}$ ratios (fig. $7 A$ ) for this study is consistent with regional patterns described by Musgrove and others (2010), where $\mathrm{Mg} / \mathrm{Ca}$ ratios increase as ${ }^{87} \mathrm{Sr} /{ }^{86} \mathrm{Sr}$ values decrease from the shallow, unconfined groundwater samples to deeper, confined groundwater samples. This pattern indicates increasing water-rock interaction and mineral-solution reactions with the carbonate aquifer rocks controlling fluid compositions as groundwater evolves from shallow, unconfined groundwater to deeper, confined groundwater. These consistent changes result from increased residence time and longer groundwater flow paths associated with the deeper, confined groundwater sites (Zarzamora well, Turtle well, Mission well, and Comal 1 spring). In contrast, the higher ${ }^{87} \mathrm{Sr} /{ }^{86} \mathrm{Sr}$ values in shallow, unconfined groundwater sites (Parkwood, Shavano, and Seco wells) indicate shorter residence times and shorter flow paths. Additionally, ${ }^{87} \mathrm{Sr} /{ }^{86} \mathrm{Sr}$ values are generally more temporally variable at the shallow, unconfined wells, likely as a result of groundwater mixing with recent, more geochemically variable recharge, particularly during the wet period. 

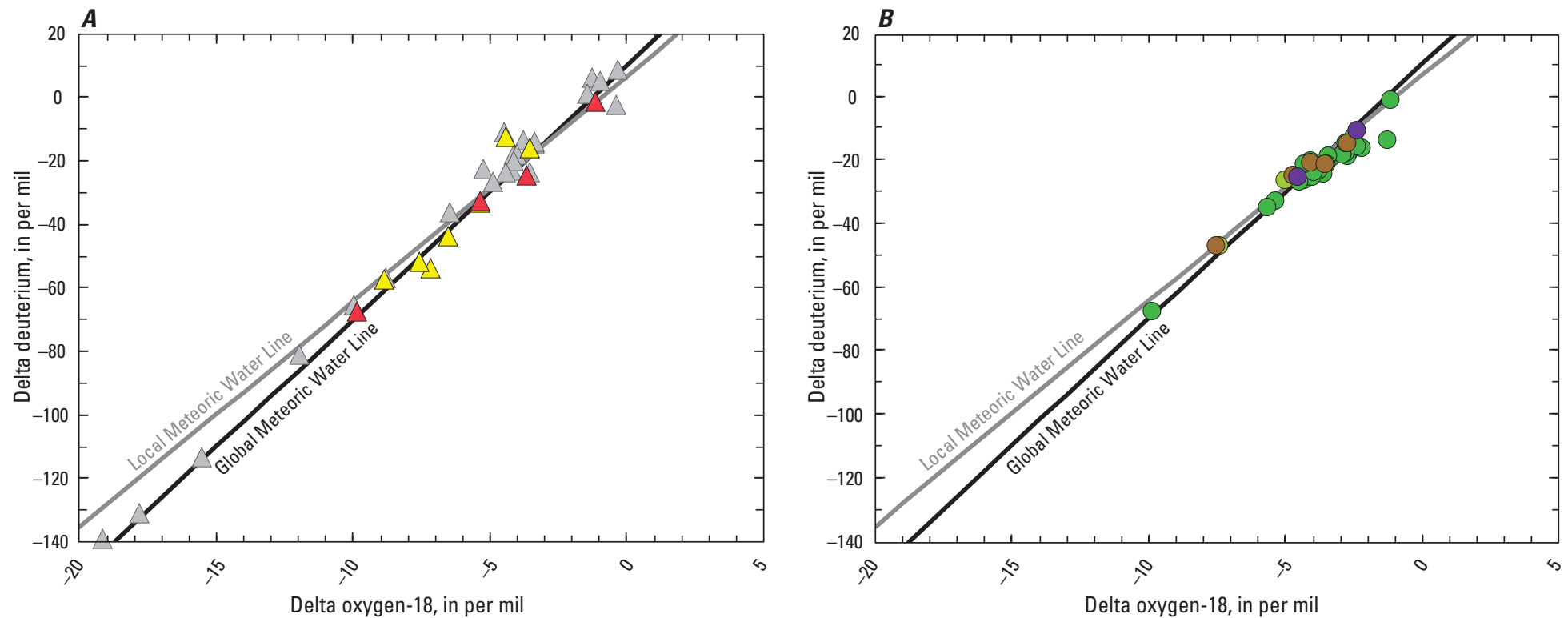

EXPLANATION

Rainfall sample, by site (fig. 1; table 1)

A Rural rainfall—Sample collected at Frio

$$
\text { River }
$$

$\triangle$ Urban rainfall (previous studies 2009-10)

$\triangle \quad$ Urban rainfall—Sample collected at Urban rainfall 1, Urban Urban rainfall 3 Surface-water sample, by site (fig. 1; table 1)

- Frio River

- Seco Creek

Culebra Creek

- Helotes Creek

Groundwater sample, by site (fig. 1; table 1)
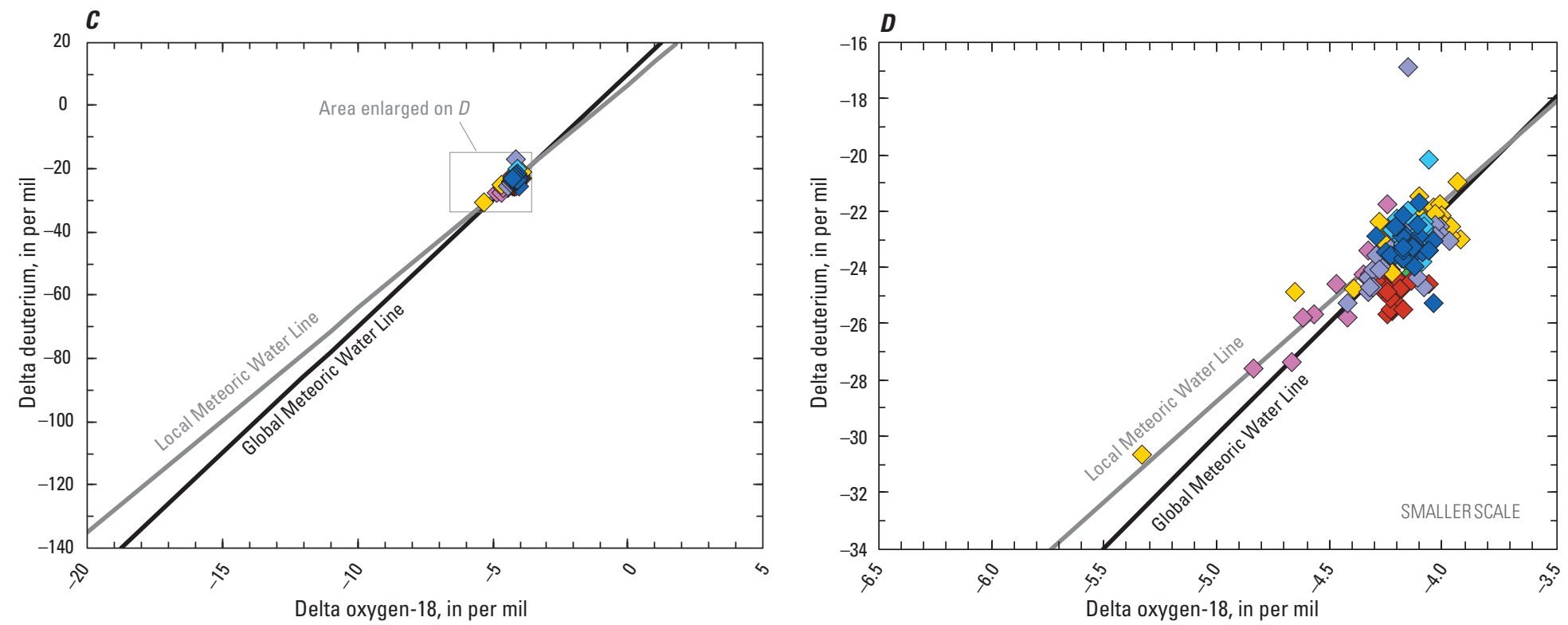

$\diamond$ Secowell

$\diamond$ Parkwood well

$\checkmark$ Shavano well

$\diamond$ Zarzamora well

$\diamond$ Turtle well

Mission well

Comal 1 spring

Figure 6. Relation between deuterium and oxygen isotopes measured in $A$, rainfall samples, $B$, surface-water samples, and $C$ and $D$, groundwater samples collected from the San Antonio segment of the Edwards aquifer, south-central Texas, 2013-16. $C$ and $D$ show the same groundwater samples at different scales. Local (Pape and others, 2010) and global (Craig, 1961) meteoric water lines are shown for comparison. 


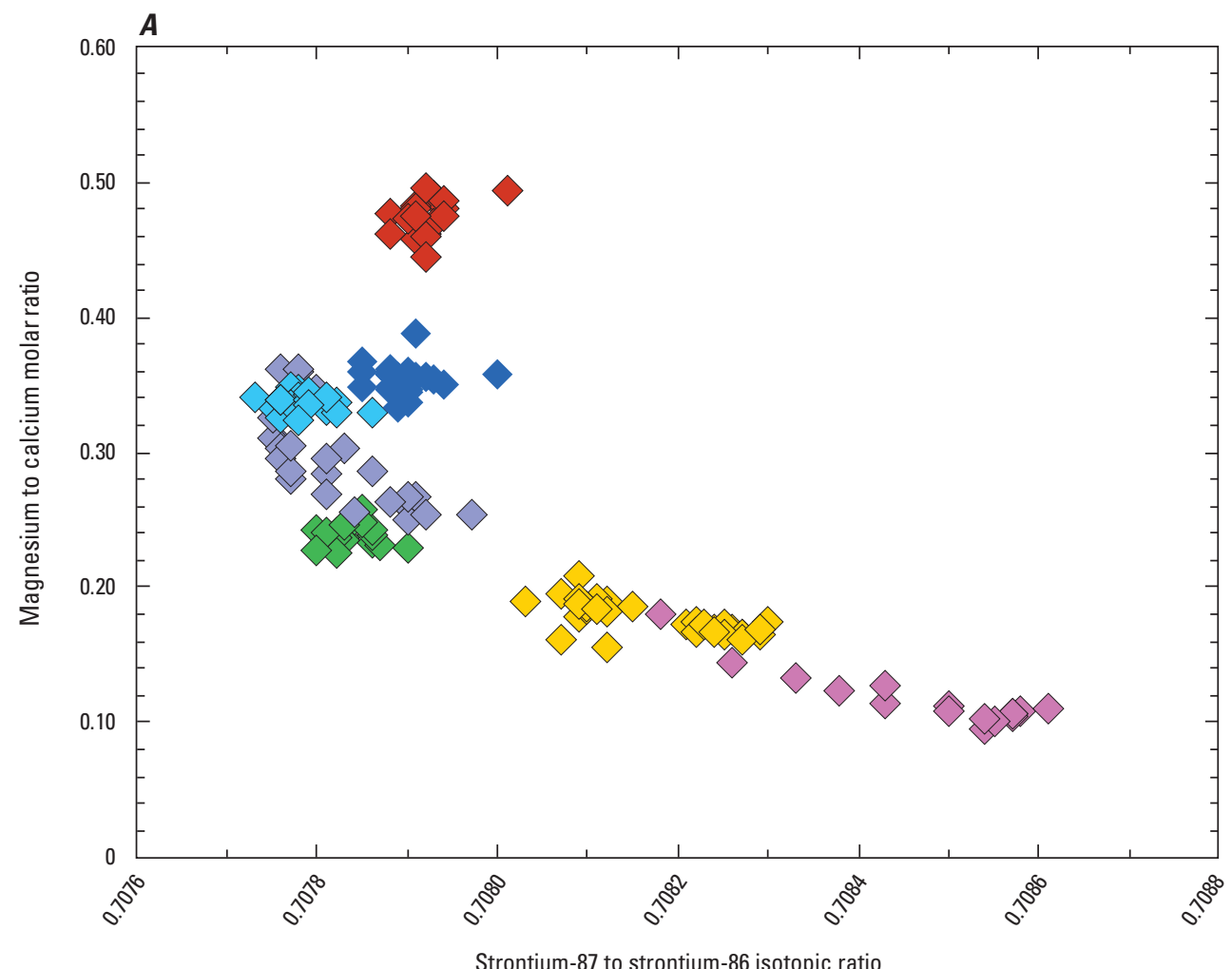

EXPLANATION

Groundwater sample, by site (fig. 1; table 1)

$>$ Seco well

$>$ Parkwood well

$>$ Shavano well

$\diamond$ Zarzamora well

$>$ Turtle well

Mission well

Comal 1 spring

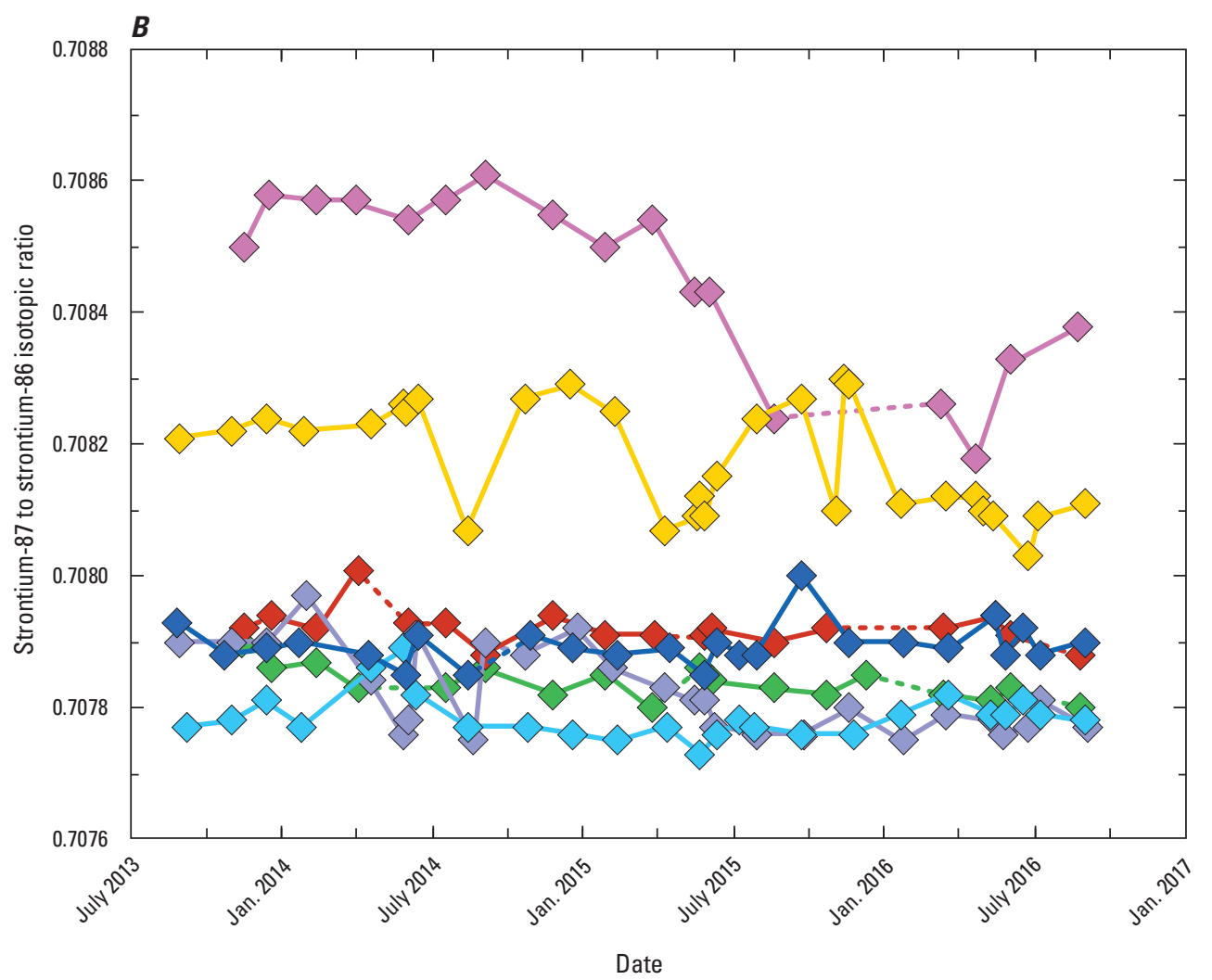

EXPLANATION

Groundwater sample, by site (fig. 1 ; table 1)Dashed where gap in data

$\checkmark$ Seco well

$>$ Parkwood well

$>$ Shavano well

$\checkmark$ Zarzamora well

$>$ Turtle well

$\checkmark$ Mission well

$\checkmark$ Comal 1 spring

Figure 7. A, Relation between strontium-87/strontium-86 isotopic ratio and magnesium to calcium molar ratio and $B$, time series of strontium-87/strontium-86 isotopic ratio measured in groundwater samples collected from the San Antonio segment of the Edwards aquifer, south-central Texas, 2013-16. 


\section{Major-Ion Distributions}

\section{Rainfall}

In the Edwards aquifer, major-ion geochemistry has been used to characterize spatial and temporal variability in water quality (Musgrove and others, 2010), although the role of rainfall and corresponding aquifer recharge in understanding major-ion dynamics is less well documented. Major-ion concentrations in rainfall samples collected from both the rural and urban rainfall sites were generally low and, in some cases, less than the LRL (table 5). Median concentrations were generally similar between rural and urban rainfall samples, but there were only four rural rainfall samples, which limits comparison for differences between rural and urban rainfall.

\section{Surface Water}

Major-ion geochemistry in surface-water samples was variable, with considerable differences in ranges and median concentrations among sites (table 6). These differences likely result from differences in hydrologic conditions at the time of sample collection. Samples from the Frio River were primarily collected during base-flow conditions, whereas samples from the other surface-water sites were collected following storms. Stormwater runoff is diluted by rainfall, which has low concentrations of major ions (table 5). Samples from the Frio River collected during base flow had higher concentrations of $\mathrm{Ca}, \mathrm{Mg}$, and Sr than did the other surface-water sites (table 6), which likely reflect groundwater contributions to base flow and lack of dilution with rainfall. Concentrations of other ions, such as $\mathrm{Cl}$ and sulfate $\left(\mathrm{SO}_{4}\right)$, at Seco Creek and Culebra Creek were notably lower than concentrations at either Helotes Creek or the Frio River; however, the small sample size for Seco Creek $(\mathrm{n}=2)$ and Culebra Creek $(\mathrm{n}=3)$ limits comparison among surface-water sites.

Table 5. Summary of selected major ions measured in rainfall samples collected from Frio River and Urban rainfall 1, 2, and 3, San Antonio segment of the Edwards aquifer, south-central Texas, 2012-16.

[LRL, laboratory reporting level; $\mathrm{Ca}$, calcium; mg/L, milligram per liter; $\mathrm{Mg}$, magnesium; $\mathrm{Na}$, sodium; $\mathrm{HCO}_{3}$, bicarbonate; $\mathrm{ND}$, not determined; $\mathrm{Cl}$, chloride; $\mathrm{SO}_{4}$, sulfate; Sr, strontium; $\mu \mathrm{g} / \mathrm{L}$, microgram per liter; $<$, less than]

\begin{tabular}{|c|c|c|c|c|c|c|c|}
\hline $\begin{array}{l}\text { Map identifier } \\
\text { (fig. 1; table 1) }\end{array}$ & $\begin{array}{c}\text { Short name } \\
\text { (fig. 1; table 1) }\end{array}$ & Constituent & $\begin{array}{c}\text { Number of } \\
\text { samples }\end{array}$ & $\begin{array}{l}\text { Number of } \\
\text { concentrations } \\
\text { equal to or } \\
\text { greater than } \\
\text { the LRL }\end{array}$ & $\begin{array}{l}\text { Minimum } \\
\text { value }\end{array}$ & $\begin{array}{l}\text { Maximum } \\
\text { value }\end{array}$ & $\begin{array}{c}\text { Median } \\
\text { value }\end{array}$ \\
\hline \multirow[t]{7}{*}{7} & Frio River ${ }^{1}$ & $\mathrm{Ca}(\mathrm{mg} / \mathrm{L})$ & 4 & 4 & 0.07 & 0.99 & 0.15 \\
\hline & & $\mathrm{Mg}(\mathrm{mg} / \mathrm{L})$ & 4 & 4 & 0.02 & 0.05 & 0.04 \\
\hline & & $\mathrm{Na}(\mathrm{mg} / \mathrm{L})$ & 4 & 4 & 0.14 & 0.26 & 0.22 \\
\hline & & $\mathrm{HCO}_{3}(\mathrm{mg} / \mathrm{L})$ & ND & ND & ND & ND & ND \\
\hline & & $\mathrm{Cl}(\mathrm{mg} / \mathrm{L})$ & 4 & 4 & 0.32 & 0.53 & 0.39 \\
\hline & & $\mathrm{SO}_{4}(\mathrm{mg} / \mathrm{L})$ & 4 & 4 & 0.3 & 1.61 & 0.81 \\
\hline & & $\operatorname{Sr}(\mu \mathrm{g} / \mathrm{L})$ & 4 & 3 & 0.5 & 2.5 & 1.0 \\
\hline \multirow[t]{7}{*}{$4,5,6$} & $\begin{array}{l}\text { Urban rainfall } \\
1,2,3\end{array}$ & $\mathrm{Ca}(\mathrm{mg} / \mathrm{L})$ & 9 & 9 & 0.03 & 1.68 & 0.47 \\
\hline & & $\mathrm{Mg}(\mathrm{mg} / \mathrm{L})$ & 9 & 7 & 0.02 & 0.15 & 0.05 \\
\hline & & $\mathrm{Na}(\mathrm{mg} / \mathrm{L})$ & 9 & 8 & $<0.06$ & 0.83 & 0.23 \\
\hline & & $\mathrm{HCO}_{3}(\mathrm{mg} / \mathrm{L})$ & 2 & 1 & $<1$ & 2 & ND \\
\hline & & $\mathrm{Cl}(\mathrm{mg} / \mathrm{L})$ & 9 & 9 & 0.07 & 1.84 & 0.45 \\
\hline & & $\mathrm{SO}_{4}(\mathrm{mg} / \mathrm{L})$ & 9 & 9 & 0.27 & 5.06 & 1.05 \\
\hline & & $\operatorname{Sr}(\mu \mathrm{g} / \mathrm{L})$ & 9 & 8 & 0.2 & 6.2 & 1.5 \\
\hline
\end{tabular}

${ }^{1}$ Rainfall samples collected at U.S. Geological Survey streamflow-gaging station 08195000 Frio River at Concan, Texas (Frio River site), were considered representative of rural rainfall. 
Table 6. Summary of selected major ions measured in water samples collected from Frio River, Seco Creek, Culebra Creek, and Helotes Creek, San Antonio segment of the Edwards aquifer, south-central Texas, 2010-16.

[LRL, laboratory reporting level; $\mathrm{Ca}$, calcium; mg/L, milligram per liter; $\mathrm{Mg}$, magnesium; $\mathrm{Na}$, sodium; $\mathrm{HCO}_{3}$, bicarbonate; $\mathrm{Cl}$, chloride; $\mathrm{SO}$, sulfate; $\mathrm{Sr}$, strontium; $\mu \mathrm{g} / \mathrm{L}$, microgram per liter; ND, not determined]

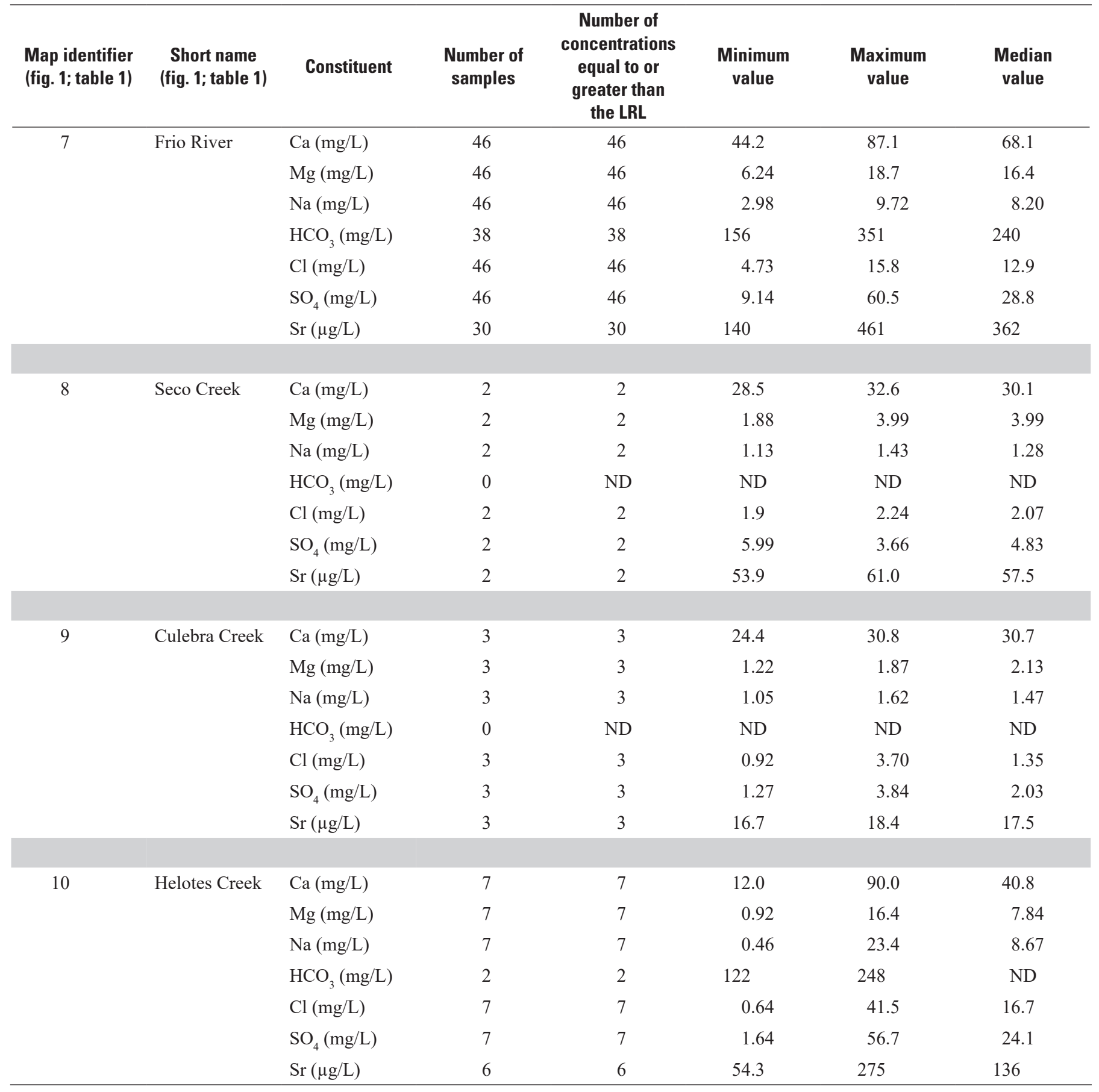




\section{Groundwater}

Major-ion concentrations measured in groundwater samples varied both temporally and spatially (figs. $8 A-G$ ). Concentrations in samples from the urban and unconfined wells (Parkwood and Shavano) were generally the most variable, which was evident during the wet period. This variability is associated with recharge during the wet period. In contrast, major-ion concentrations in samples collected from the rural and unconfined site (Seco well) were generally less variable. This contrast in the variability of major-ion geochemistry among the unconfined sites is consistent with the contrast in the variability in $\mathrm{SC}$ among these sites (figs. $5 A-C$ ) also indicating that Seco well is less connected to localized groundwater recharge sources than are Parkwood and Shavano wells. Major-ion concentrations measured in the confined Mission well were distinct from those at the other wells, with much higher concentrations of $\mathrm{Cl}$ and, in particular, $\mathrm{Sr}$ (figs. 8E, G). These differences in concentration of major ions are consistent with mixing with a small component of saline groundwater at the Mission well.

Changes in major-ion geochemistry over the multiyear study period were evident at only a few sites and for only a few compounds (figs. $8 A-G$ ). $\mathrm{Mg}$ and $\mathrm{SO}_{4}$ concentrations increased at the unconfined Shavano well, although a similar change was not observed at Parkwood well. The changes in $\mathrm{Mg}$ and $\mathrm{SO}_{4}$ at Shavano well were associated with changes in environmental concentrations rather than sampling variability given the very low range in RPDs associated with sample processing (table 4). Major-ion concentrations at Zarzamora and Turtle wells, which are both relatively deep confined wells, were generally similar to each other and relatively constant, with no notable temporal variability. At Comal 1 spring site, concentrations of sodium ( $\mathrm{Na}$ ), $\mathrm{Cl}$, and $\mathrm{SO}_{4}$ decreased slightly over the study period. Although the magnitude of change in $\mathrm{Na}$ and $\mathrm{Cl}$ was smaller than that for $\mathrm{SO}_{4}$, only part of the variability in $\mathrm{Na}$ and $\mathrm{Cl}$ may be attributed to sample processing based on low RPDs observed for replicate samples (table 4), indicating that environmental changes, although variable, were occurring with these constituents. These gradual shifts to lower concentrations might reflect slow changes in regional flow paths in response to increased recharge containing a higher proportion of younger water. Minor temporal changes in major-ion concentrations at the confined groundwater sites (Zarzamora well, Turtle well, and Comal 1 spring) contrast with the enhanced variability at shallow recharge-zone sites (Parkwood well and Shavano well) that was evident during periods of rapid groundwater recharge, highlighting the importance of periods of rapid hydrologic change in contributing groundwater chemistry.

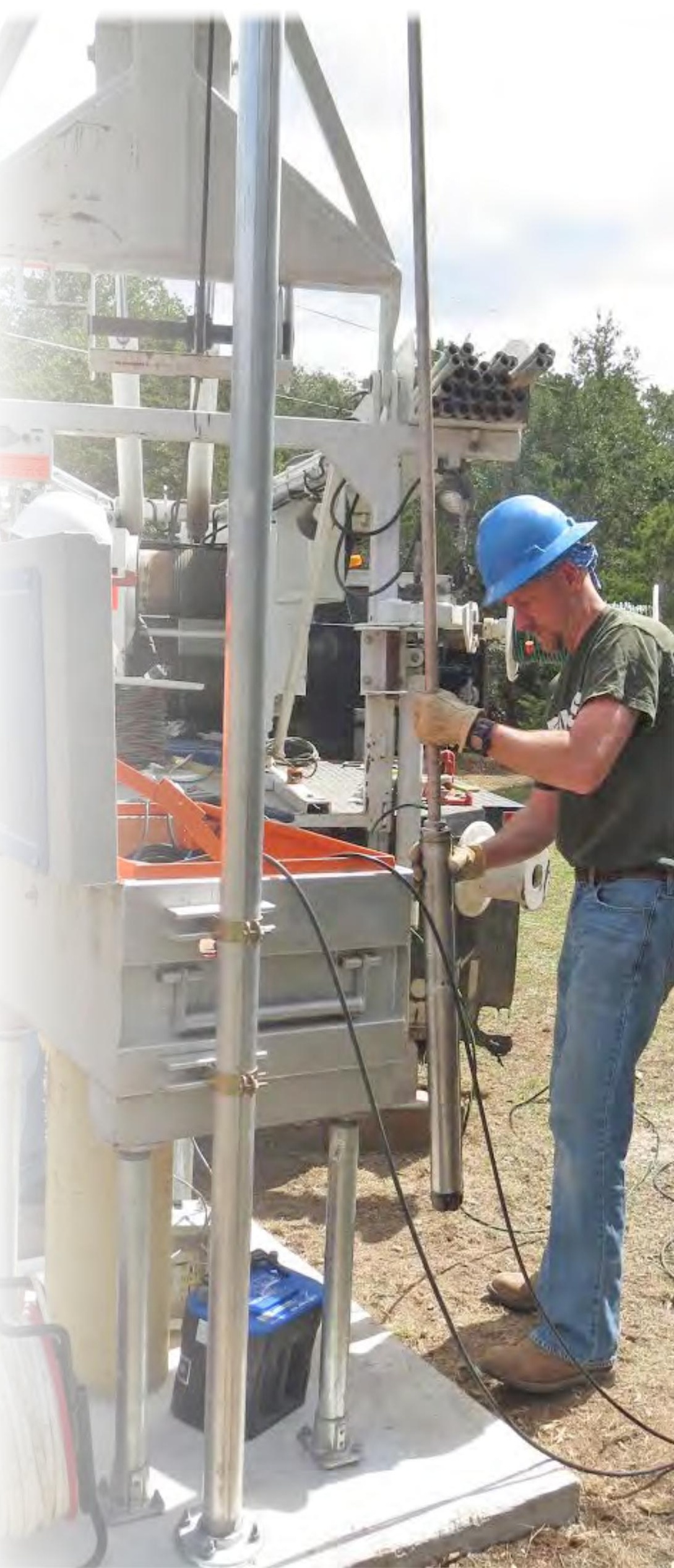



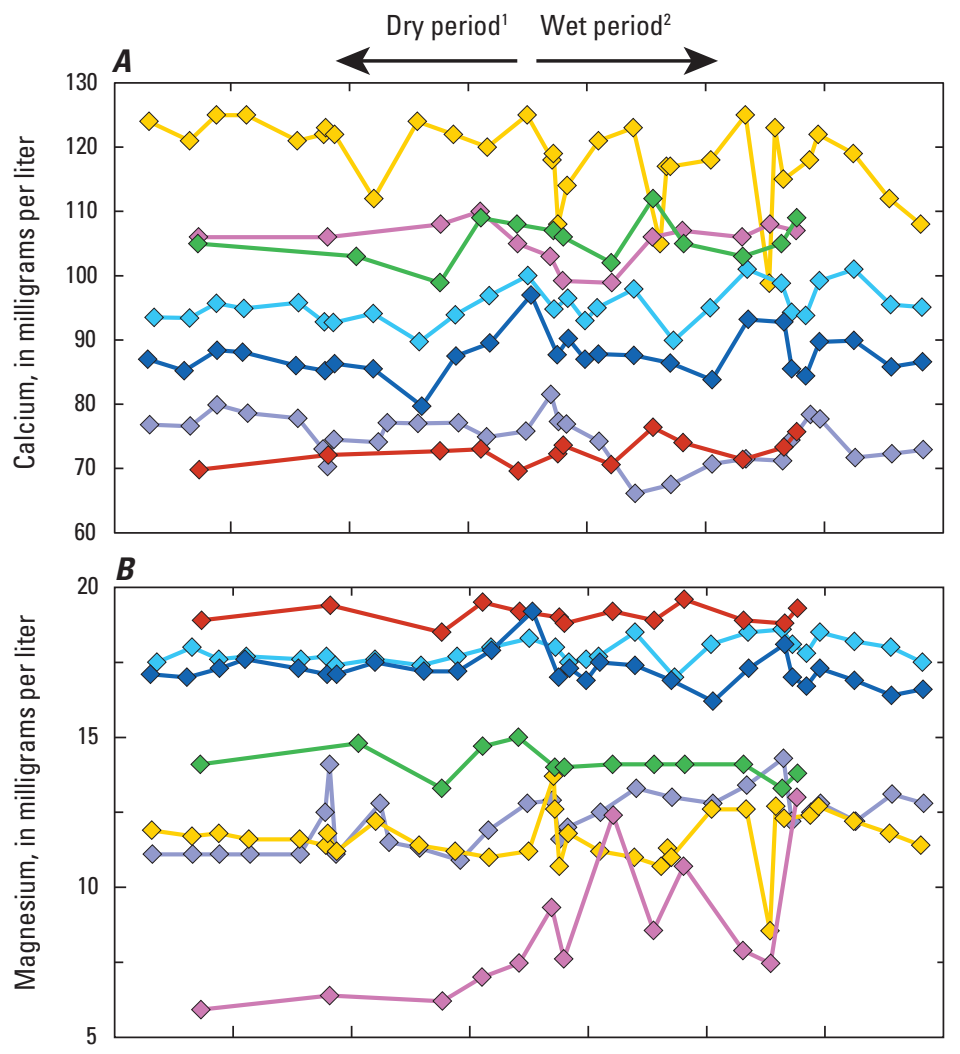

EXPLANATION

Groundwater sample,

by site (fig. 1; table 1)

$\diamond$ Seco well

$\diamond \quad$ Parkwood well

$\checkmark$ Shavano well

$\diamond \quad$ Zarzamora well

$\diamond \quad$ Turtle well

$\prec$ Mission well

$\neg$ Comal 1 spring

July 2013 through May 2015 is referred to as the "dry period."

2June 2015 through December 2016 is referred to as the "wet period."
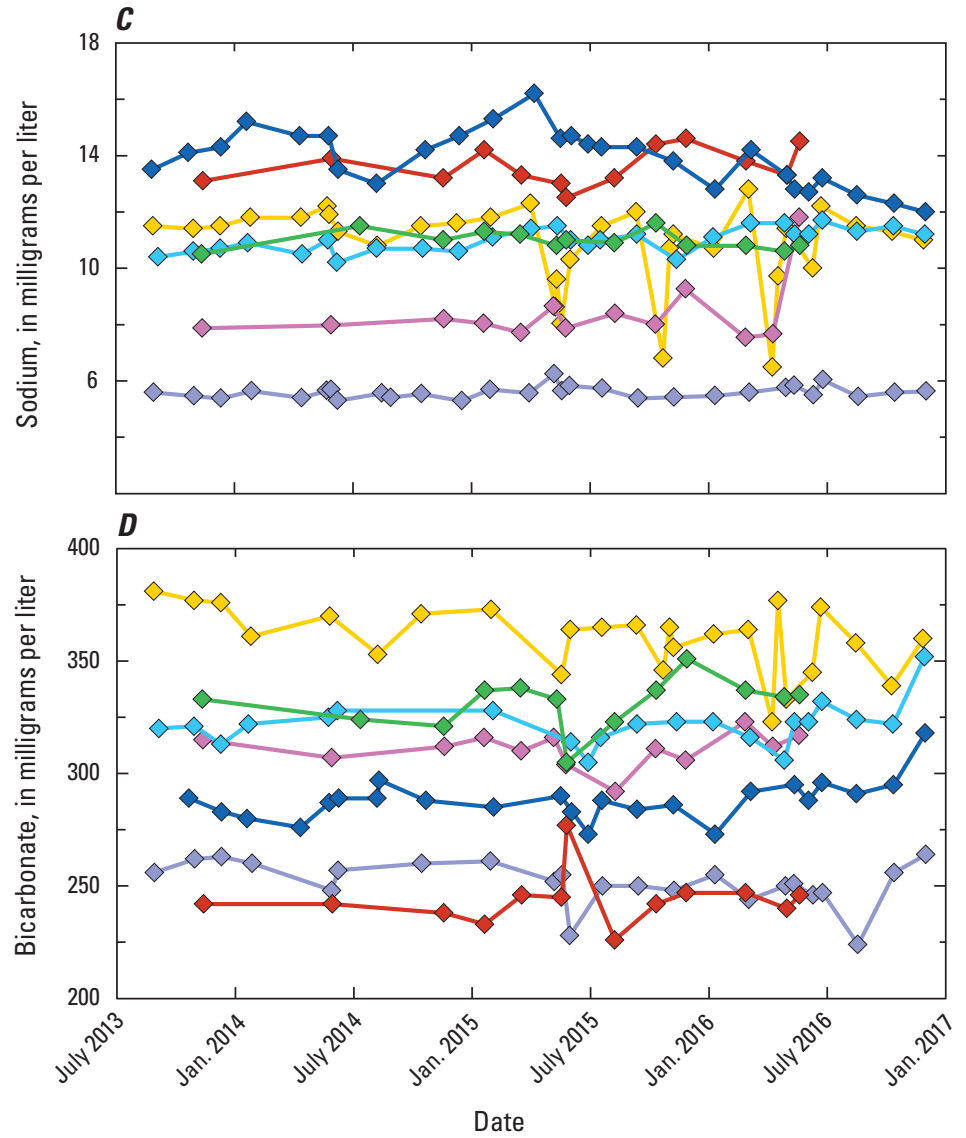

Figure 8. Concentrations of $A$, calcium, $B$, magnesium, $C$, sodium, $D$, bicarbonate, $E$, chloride, $F$, sulfate, and $G$, strontium measured in groundwater samples and Comal 1 spring samples collected from the San Antonio segment of the Edwards aquifer, south-central Texas, July 2013-December 2016. 

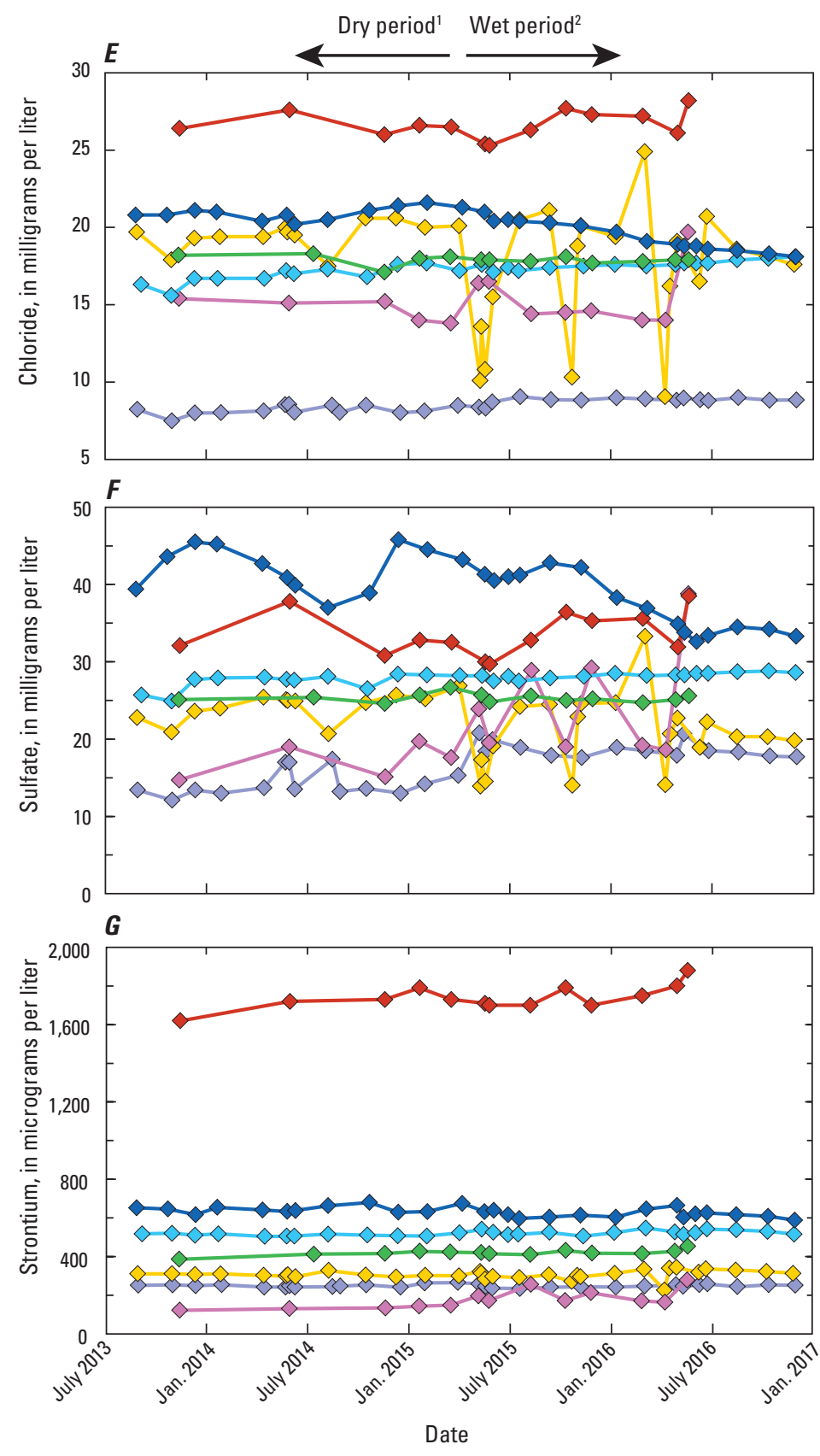

EXPLANATION

Groundwater sample,

by site (fig. 1; table 1)

$\diamond$ Secowell

$\diamond \quad$ Parkwood well

$\prec$ Shavano well

$\diamond \quad$ Zarzamora well

$\prec$ Turtle well

$\neg$ Mission well

$\neg \quad$ Comal 1 spring

'July 2013 through May 2015 is referred to as the "dry period."

2June 2015 through December 2016 is referred to as the "wet period."

Figure 8. Concentrations of $A$, calcium, $B$, magnesium, $C$, sodium, $D$, bicarbonate, $E$, chloride, $F$, sulfate, and $G$, strontium measured in groundwater samples and Comal 1 spring samples collected from the San Antonio segment of the Edwards aquifer, south-central Texas, July 2013-December 2016.-Continued 


\section{Nutrient Geochemistry}

\section{Rainfall}

Rainfall samples often contained measurable concentrations of $\mathrm{NO}_{3}, \mathrm{NO}_{2}, \mathrm{DON}$, and ortho-P at both rural and urban rainfall sites, indicating that atmospheric deposition is a source of $\mathrm{N}$ and $\mathrm{P}$ to the study area (table 7). Median concentrations of total-N were $0.30 \mathrm{mg} / \mathrm{L}$ (range $=0.13-$ $0.65 \mathrm{mg} / \mathrm{L}$ ) and $0.49 \mathrm{mg} / \mathrm{L}$ (range $=<0.10-0.59 \mathrm{mg} / \mathrm{L}$ ) for rural $(n=4)$ and urban $(n=9)$ rainfall samples, respectively. At both urban and rural rainfall sites, $\mathrm{NH}_{4}$ consistently had the highest median concentration among $\mathrm{N}$ species, followed by $\mathrm{NO}_{3}$ and DON. Concentrations of ortho-P were low or not detectable in many samples, and the highest concentration $(0.023 \mathrm{mg} / \mathrm{L})$ was measured in a sample of urban rainfall. These results are consistent with the range in ortho-P concentrations $(<0.004-0.077 \mathrm{mg} / \mathrm{L})$ measured in rainfall samples collected in south-central Texas in 2015-16 (Lambert and others, 2017). A broad range in ortho-P concentrations in regional rainfall samples indicates that, at times, atmospheric deposition of ortho-P should be considered a potential source input to the aquifer.

\section{Surface Water}

Relative proportions of $\mathrm{N}$ species in surface water $\left(\mathrm{NH}_{4}\right.$, $\mathrm{NO}_{3}$, and $\mathrm{DON}$ ) varied among surface-water sites. $\mathrm{NO}_{3}$ was detected in all surface-water samples, ranging in concentration from 0.05 to $2.02 \mathrm{mg} / \mathrm{L}$, and was the dominant $\mathrm{N}$ species (based on median values) at most surface-water sites (table 8). The exception was Culebra Creek, where the dominant $\mathrm{N}$ species was DON. DON was the second highest concentration of $\mathrm{N}$ species at Helotes Creek; a median value could not be calculated for Seco Creek. $\mathrm{NH}_{4}$ concentrations at all surfacewater sites were usually low relative to $\mathrm{NO}_{3}$ and $\mathrm{DON}$, but ranged from $<0.01$ to $0.06 \mathrm{mg} / \mathrm{L}$.

Table 7. Summary of selected nutrients and stable nitrogen and oxygen isotopes of nitrate (delta nitrogen-15 in nitrate and delta oxygen-18 in nitrate) measured in rainfall samples collected from Frio River (representative of rural land cover) and Urban rainfall 1, 2, and 3, San Antonio segment of the Edwards aquifer, south-central Texas, 2012-16.

[LRL, laboratory reporting level; $\mathrm{NH}_{4}-\mathrm{N}$, ammonia as nitrogen; mg/L, milligram per liter; $\mathrm{NO}_{3}-\mathrm{N}$, nitrate as nitrogen; $\mathrm{NO}_{2}-\mathrm{N}$, nitrite as nitrogen; <, less than; $\mathrm{ND}$, not determined; DON, dissolved organic nitrogen; ortho-P, orthophosphate as phosphorus; total-N, total nitrogen; $\delta^{15} \mathrm{~N}-\mathrm{NO}_{3}$, delta nitrogen-15 in nitrate; $\delta^{18} \mathrm{O}^{-\mathrm{NO}_{3}}$, delta oxygen-18 in nitrate]

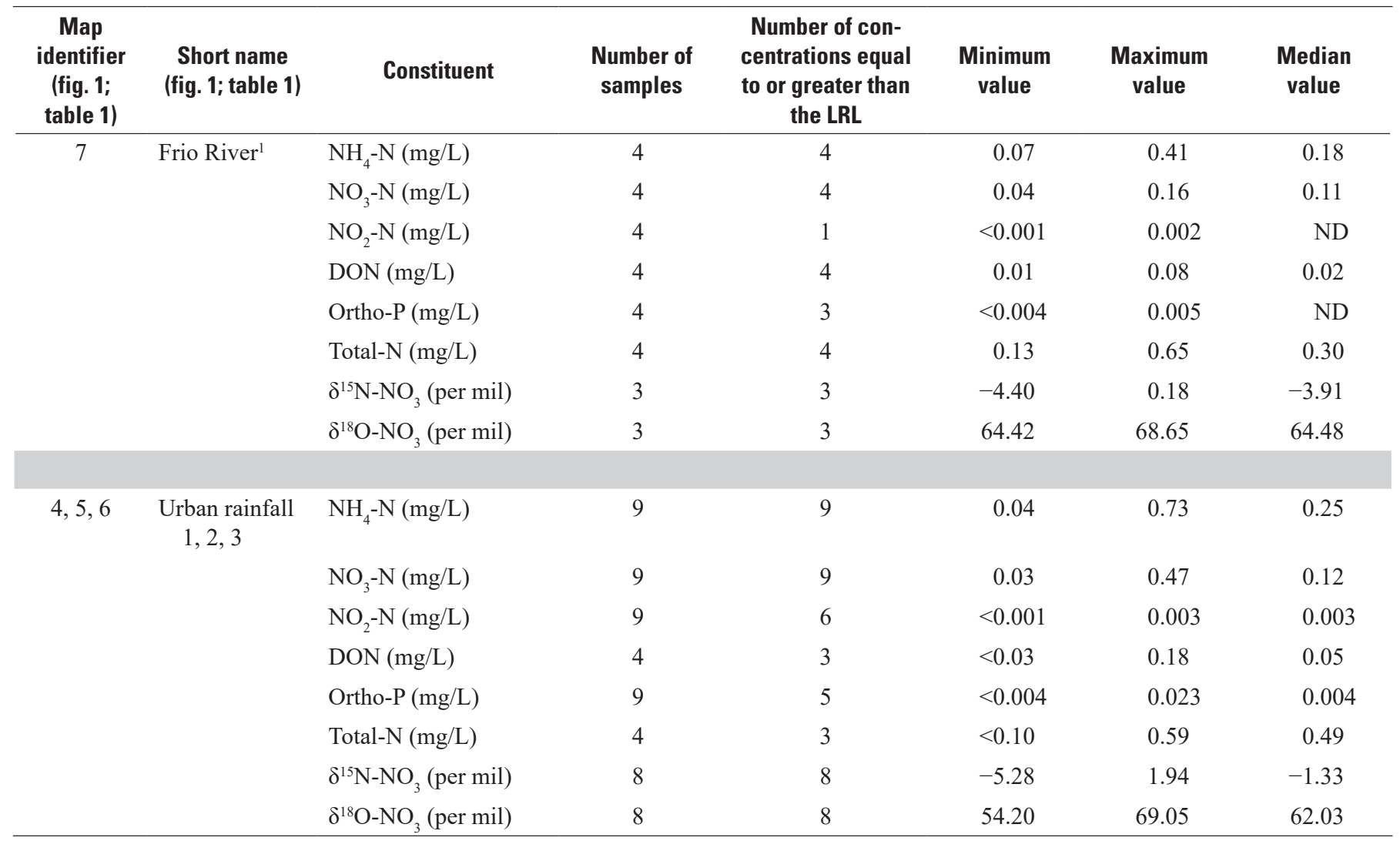

${ }^{1}$ Rainfall samples collected at U.S. Geological Survey streamflow-gaging station 08195000 Frio River at Concan, Texas (Frio River site), were considered representative of rural rainfall. 
Table 8. Summary of selected nutrients and stable nitrogen and oxygen isotopes of nitrate (delta nitrogen-15 in nitrate and delta oxygen-18 in nitrate) measured in surface-water samples collected from Frio River, Seco Creek, Culebra Creek, and Helotes Creek, San Antonio segment of the Edwards aquifer, south-central Texas, 2010-16.

[LRL, laboratory reporting level; $\mathrm{NH}_{4}-\mathrm{N}$, ammonia as nitrogen; $\mathrm{mg} / \mathrm{L}$, milligram per liter; <, less than; $\mathrm{ND}$, not determined; $\mathrm{NO}_{3}-\mathrm{N}$, nitrate as nitrogen; $\mathrm{NO}_{2}-\mathrm{N}$, nitrite as nitrogen, DON, dissolved organic nitrogen; ortho-P, orthophosphate as phosphorus; total-N, total nitrogen; $\delta^{15} \mathrm{~N}-\mathrm{NO}_{3}$, delta nitrogen-15 in nitrate; $\delta^{18} \mathrm{O}-\mathrm{NO}_{3}$, delta oxygen-18 in nitrate]

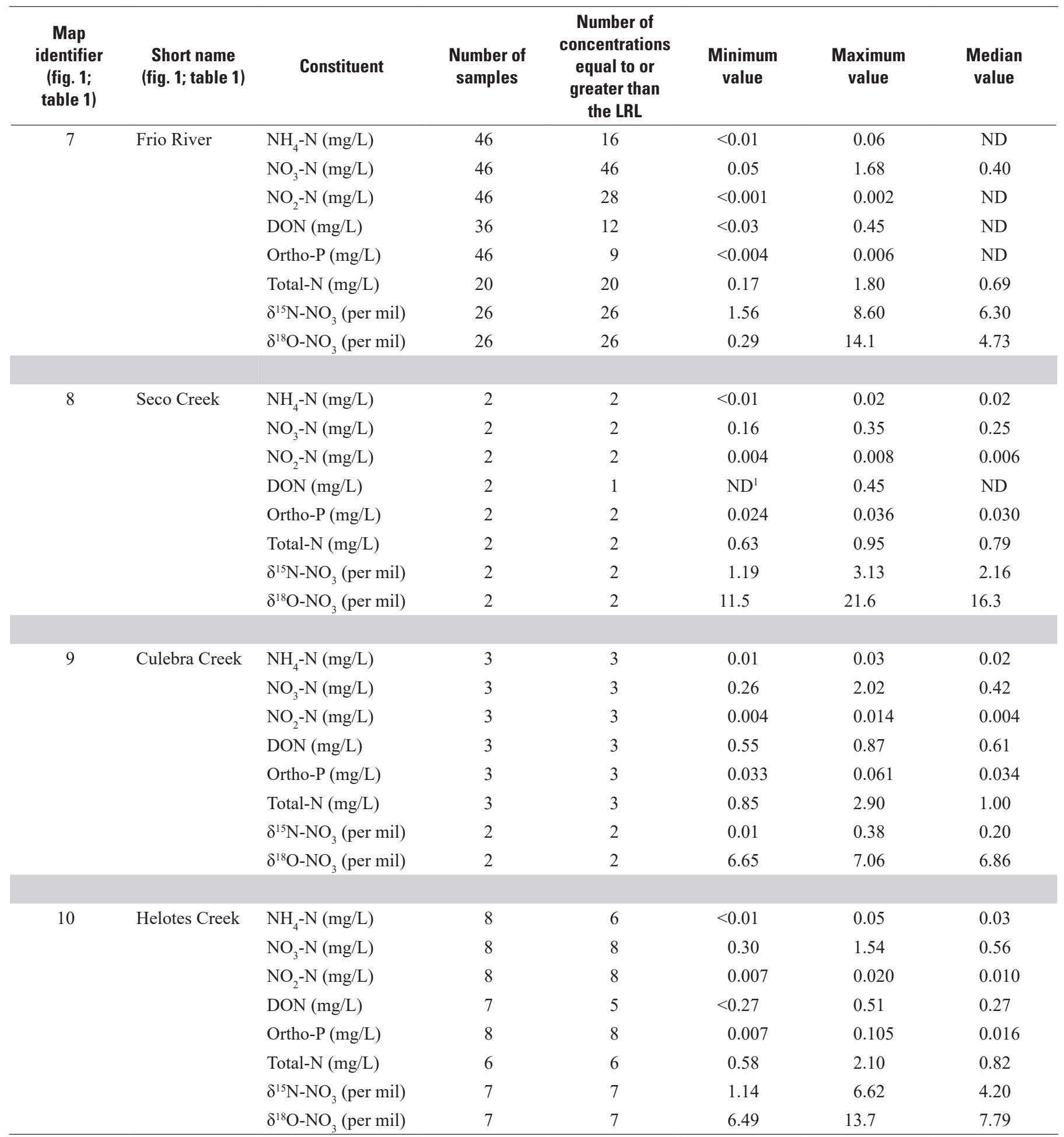

${ }^{1}$ A concentration of $<0.59$ was measured in one of the two samples when the LRL was $0.59 \mathrm{mg} / \mathrm{L}$. 
Seco, Culebra, and Helotes Creeks are ephemeral and flow only in response to rainfall events; therefore, fewer samples were collected at these sites than at the Frio River (table 8). The lowest median daily discharge at the Frio River during this study was $5.49 \mathrm{ft}^{3} / \mathrm{s}$ on September 7, 2013 (fig. 4). Samples were collected at the Frio River during both base-flow and stormwater-runoff conditions, although more samples were collected during base-flow conditions. As a result, nutrient species concentrations varied over a wide range of flow conditions in comparison to other surfacewater sites. $\mathrm{NO}_{3}$ concentrations measured in samples from the Frio River ranged from 0.05 to $1.68 \mathrm{mg} / \mathrm{L}$ (table 8), although slightly higher values (about $2.0 \mathrm{mg} / \mathrm{L}$ ) were measured by the continuous $\mathrm{NO}_{3}$ sensor (discussed in the section "Continuous Nitrate Monitoring"). The median $\mathrm{NO}_{3}$ concentrations at surface-water sites (ranging from 0.25 to $0.56 \mathrm{mg} / \mathrm{L}$; table 8) were similar to or higher than the estimated national background concentration for streams of $0.24 \mathrm{mg} / \mathrm{L}$ (Dubrovsky and others, 2010). The highest median $\mathrm{NO}_{3}$ concentration was at Helotes Creek (0.56 $\mathrm{mg} / \mathrm{L}$; table 8), which is about twice the estimated national background concentration for streams in undeveloped areas $(0.24 \mathrm{mg} / \mathrm{L})$ but less than the estimated national background concentration for urban streams (about $0.8 \mathrm{mg} / \mathrm{L}$ ) (Dubrovsky and others, 2010). This higher concentration at Helotes Creek might result from a contribution of $\mathrm{NO}_{3}$ from urban sources. The estimated national background for streams in agricultural areas is about $2.7 \mathrm{mg} / \mathrm{L}$, and the excess $\mathrm{NO}_{3}$ in these streams is attributed primarily to fertilizer application (Dubrovsky and others, 2010). Median $\mathrm{NO}_{3}$ concentrations for both rural $(0.25-0.42 \mathrm{mg} / \mathrm{L})$ and urban $(0.56 \mathrm{mg} / \mathrm{L})$ surface-water sites examined in this study (table 8) were substantially lower than the national background concentration for streams in agricultural areas (about $2.7 \mathrm{mg} / \mathrm{L}$; Dubrovsky and others, 2010) and are therefore consistent with minor inputs of agricultural fertilizer.

Ortho-P was detected in all samples collected from Seco, Culebra, and Helotes Creeks, but in only about 20 percent of the samples from the Frio River (table 8). Median concentrations of ortho-P for Seco, Culebra, and Helotes Creeks ranged from 0.016 to $0.034 \mathrm{mg} / \mathrm{L}$ (table 8), slightly higher than the national background concentration of $0.010 \mathrm{mg} / \mathrm{L}$ (Dubrovsky and others, 2010). The median concentration of ortho-P for the Frio River was not determined; however, samples with detections were generally associated with higher flow conditions and likely had a storm-runoff component. These results indicate that the base-flow component of Frio River discharge, which is supported primarily by groundwater springs, typically has little to no ortho-P.

\section{Groundwater}

$\mathrm{NO}_{3}$ concentrations in groundwater samples were above the LRL, and $\mathrm{NO}_{3}$ was the most abundant $\mathrm{N}$ species at all groundwater sites (table 9). The lowest and highest median $\mathrm{NO}_{3}$ concentrations were measured at the rural Seco well $(1.04 \mathrm{mg} / \mathrm{L})$ and the urban Parkwood well $(2.65 \mathrm{mg} / \mathrm{L})$, respectively. In contrast, $\mathrm{NH}_{4}$ and DON were infrequently detected in groundwater, especially at the confined groundwater sites and at Comal 1 spring, where $\mathrm{NH}_{4}$ was detected only once (at Turtle well) and DON was not detected. Ortho-P was detected in all groundwater samples, with median concentrations ranging from $0.007 \mathrm{mg} / \mathrm{L}$ at Seco and Mission wells to $0.018 \mathrm{mg} / \mathrm{L}$ at Shavano well; ortho-P at Shavano well was substantially higher in concentration than at the other groundwater sites. Median ortho-P values at all of the groundwater sites were less than the estimated national background value for groundwater of $0.030 \mathrm{mg} / \mathrm{L}$ (Dubrovsky and others, 2010).

$\mathrm{NO}_{3}$ concentrations in groundwater samples (fig. 9A) varied much less than in surface-water samples (table 8), except at the unconfined urban Parkwood well during the wet period. Relatively low $\mathrm{NO}_{3}$ concentrations at Parkwood well were associated with samples collected in response to recharge events. For many of these samples, $\mathrm{NO}_{3}$ concentrations were less than $1.0 \mathrm{mg} / \mathrm{L}$; between these storm-response samples, $\mathrm{NO}_{3}$ concentrations at Parkwood well returned to an ambient concentration between about 2.5 and $3.0 \mathrm{mg} / \mathrm{L}$ (fig. $9 A$ ). At Shavano well, few storm-response samples were collected, so most samples represent ambient groundwater conditions. $\mathrm{NO}_{3}$ concentrations at Shavano well were typically higher during the dry period (around $2 \mathrm{mg} / \mathrm{L}$ ) and consistently lower during the wet period (around $1.6 \mathrm{mg} / \mathrm{L}$ ). This decrease in $\mathrm{NO}_{3}$ concentration during the wet period likely reflects mixing with a larger component of recent, lower $\mathrm{NO}_{3}$ recharge water. Similar to Parkwood well, this site is characterized by a rapid response to rainfall and recharge events (fig. 5C).

Temporal variability in ortho-P was generally small, but was apparent at several sites (fig. 9B). The most dynamic variability was at Shavano well, where ortho-P concentrations decreased from about 0.020 to $0.012 \mathrm{mg} / \mathrm{L}$ over the course of the study. Turtle and Mission wells also had small decreases in ortho-P concentrations, consistent with lower concentrations during the wet period. Longer term data that capture additional hydrologic variability would aid in determining if there are consistent temporal patterns in ambient ortho-P concentrations at these sites. 
Table 9. Summary of selected nutrients and stable nitrogen and oxygen isotopes of nitrate (delta nitrogen-15 in nitrate and delta oxygen-18 in nitrate) measured in samples collected from groundwater wells and Comal 1 spring, San Antonio segment of the Edwards aquifer, south-central Texas, 2013-16.

[LRL, laboratory reporting level; $\mathrm{NH}_{4}-\mathrm{N}$, ammonia as nitrogen; $\mathrm{mg} / \mathrm{L}$, milligram per liter; <, less than; $\mathrm{ND}$, not determined; $\mathrm{NO}_{3}-\mathrm{N}$, nitrate as nitrogen; $\mathrm{NO}_{2}-\mathrm{N}$, nitrite as nitrogen, DON, dissolved organic nitrogen; ortho-P, orthophosphate as phosphorus; total-N, total nitrogen; $\delta^{15} \mathrm{~N}-\mathrm{NO}_{3}$, delta nitrogen-15 in nitrate; $\delta^{18} \mathrm{O}_{-} \mathrm{NO}_{3}$, delta oxygen-18 in nitrate]

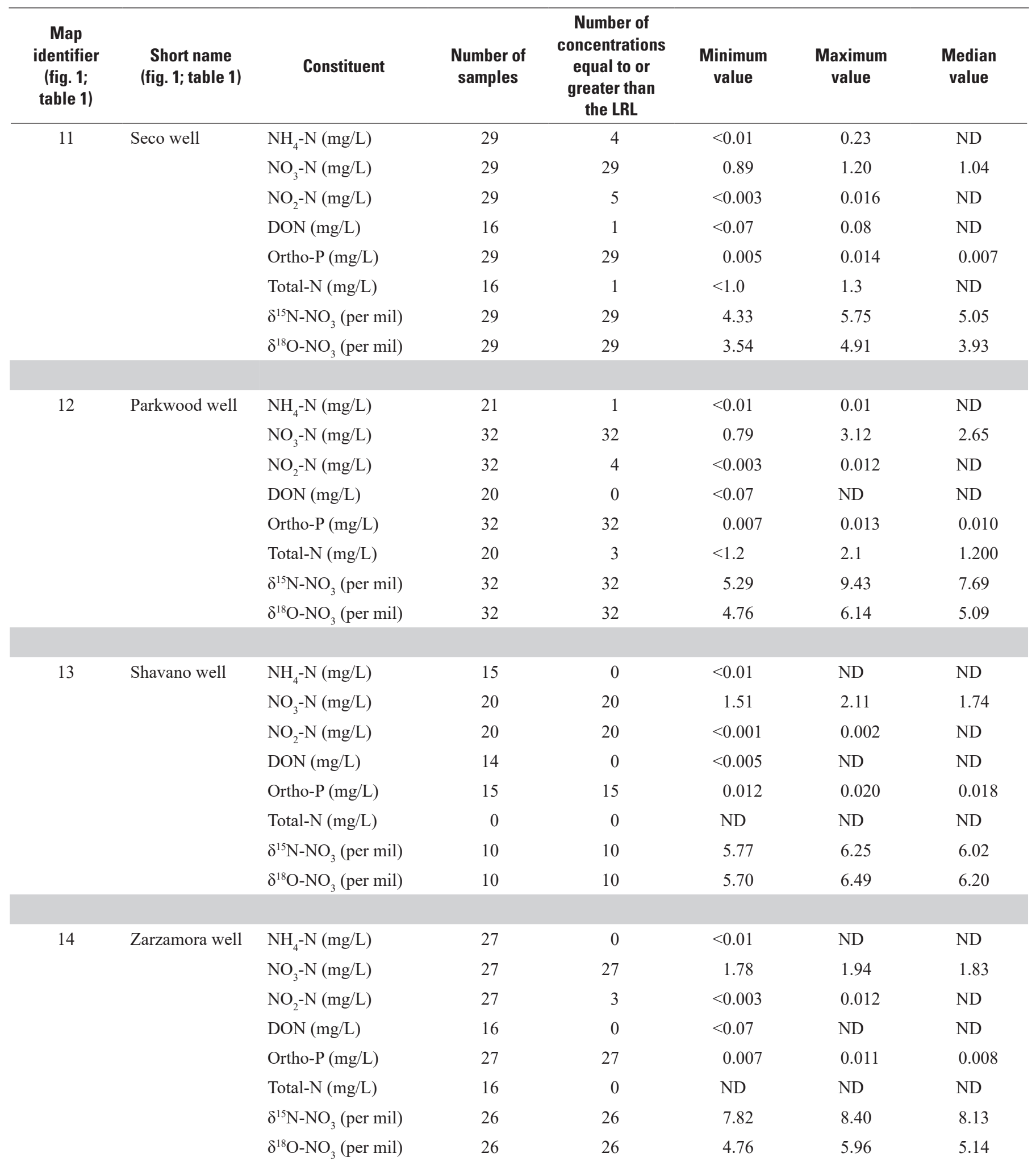


Table 9. Summary of selected nutrients and stable nitrogen and oxygen isotopes of nitrate (delta nitrogen-15 in nitrate and delta oxygen-18 in nitrate) measured in samples collected from groundwater wells and Comal 1 spring, San Antonio segment of the Edwards aquifer, south-central Texas, 2013-16.-Continued

[LRL, laboratory reporting level; $\mathrm{NH}_{4}-\mathrm{N}$, ammonia as nitrogen; $\mathrm{mg} / \mathrm{L}$, milligram per liter; <, less than; $\mathrm{ND}$, not determined; $\mathrm{NO}_{3}-\mathrm{N}$, nitrate as nitrogen; $\mathrm{NO}_{2}-\mathrm{N}$, nitrite as nitrogen, DON, dissolved organic nitrogen; ortho-P, orthophosphate as phosphorus; total-N, total nitrogen; $\delta^{15} \mathrm{~N}^{-\mathrm{NO}_{3}}$, delta nitrogen-15 in nitrate; $\delta^{18} \mathrm{O}-\mathrm{NO}_{3}$, delta oxygen-18 in nitrate]

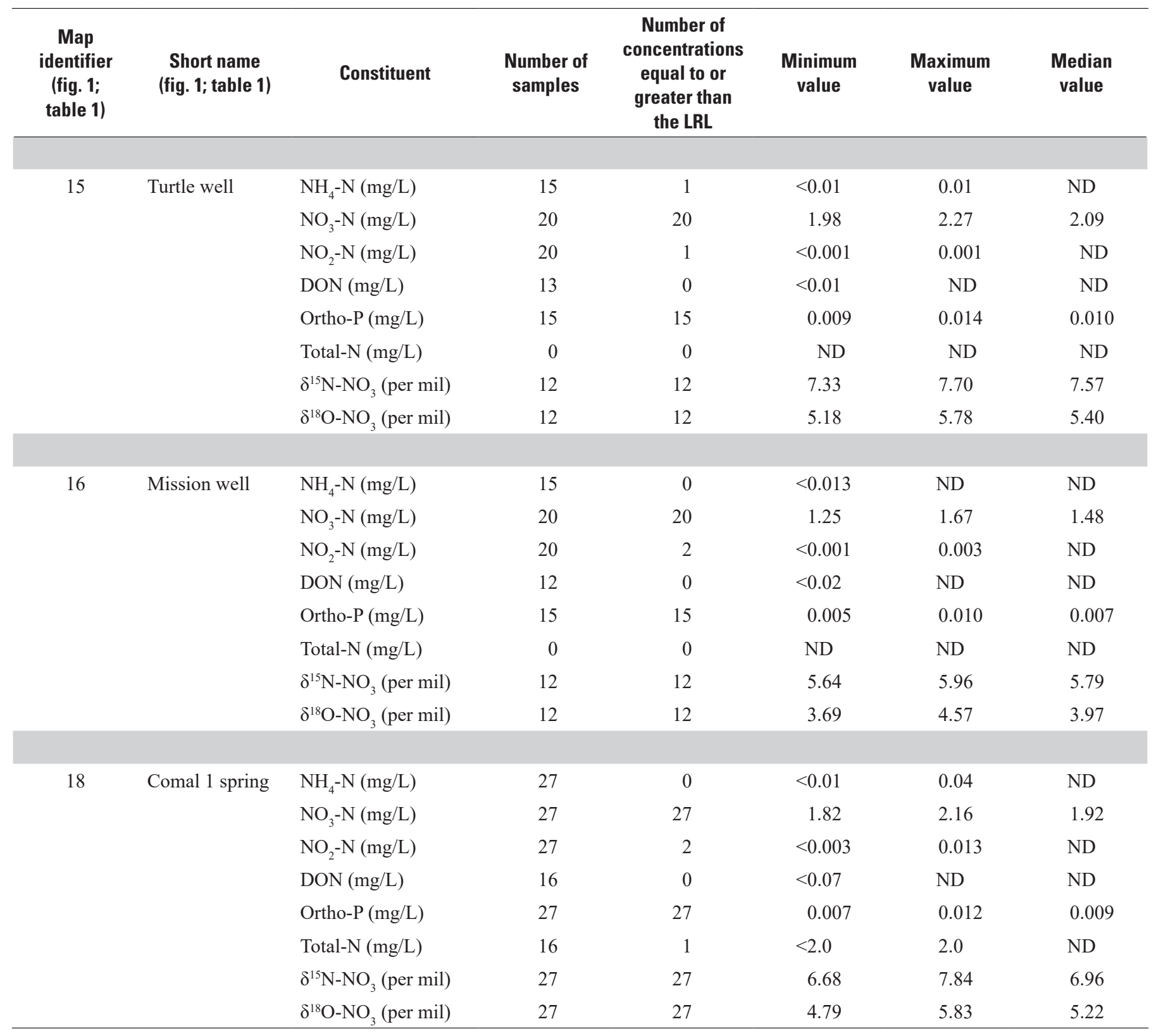



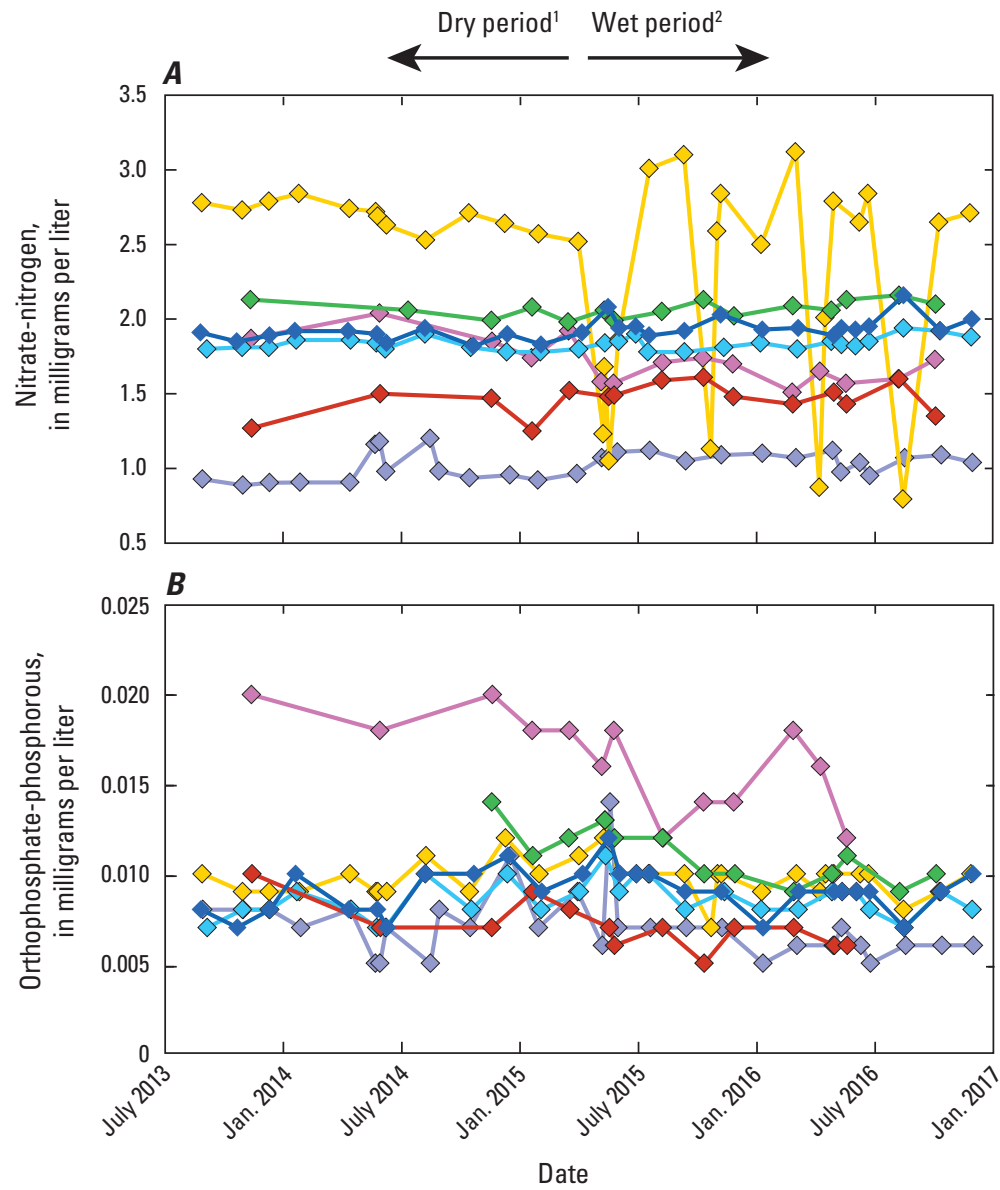

EXPLANATION

Groundwater sample by site (fig. 1; table 1)

$\checkmark$ Secowell

$\diamond \quad$ Parkwood well

$\checkmark \quad$ Shavano well

$\checkmark \quad$ Zarzamora well

$\checkmark \quad$ Turtle well

$\neg$ Mission well

$\smile \quad$ Comal 1 spring

'July 2013 through May 2015 is referred to as the "dry period."

2June 2015 through December 2016 is referred to as the "wet period."

Figure 9. Concentrations of $A$, nitrate-nitrogen and $B$, orthophosphate-phosphorous measured in water samples collected from groundwater wells and Comal 1 spring, San Antonio segment of the Edwards aquifer, south-central Texas, July 2013-December 2016. 


\section{Continuous Nitrate Monitoring}

\section{Surface Water}

Continuous $\mathrm{NO}_{3}$ monitoring, which began at the Frio River in September 2015 (fig. 10), provides more detail about temporal $\mathrm{NO}_{3}$ variability than do the discrete samples (fig. 9). Comparison of $\mathrm{NO}_{3}$ concentrations and discharge showed a consistent pattern of low $\mathrm{NO}_{3}$ concentrations measured during base-flow conditions and higher $\mathrm{NO}_{3}$ concentrations measured during high-flow conditions. A large rainfall-recharge event in September 2016 resulted in the highest discharge at the Frio River during the period of continuous monitoring and illustrates the consistent relations between $\mathrm{NO}_{3}$ concentration, streamflow, and SC (fig. 11). As discharge increased initially, SC decreased rapidly, consistent with rapid runoff of lowconductance stormwater-runoff from rainfall. During the initial rise in discharge, an increase in turbidity was evident based on visual observations, and a corresponding gap in the continuous $\mathrm{NO}_{3}$ data occurred. $\mathrm{NO}_{3}$ sensor measurements resumed about midway through the discharge peak, recording a corresponding steady and rapid increase in concentration from about 0.4 to $2.0 \mathrm{mg} / \mathrm{L}$. The $\mathrm{NO}_{3}$ increase was temporally delayed relative to the discharge increase, occurring when the storm pulse was receding. This lag in the $\mathrm{NO}_{3}$ concentration increase is hypothesized to primarily result from a delay in $\mathrm{NO}_{3}$ mobilization from soils. Prior studies in other watersheds (Lucey and Goolsby, 1993; Reynolds and Edwards, 1995;

Rusjan and others, 2008) have recorded $\mathrm{NO}_{3}$ increases during

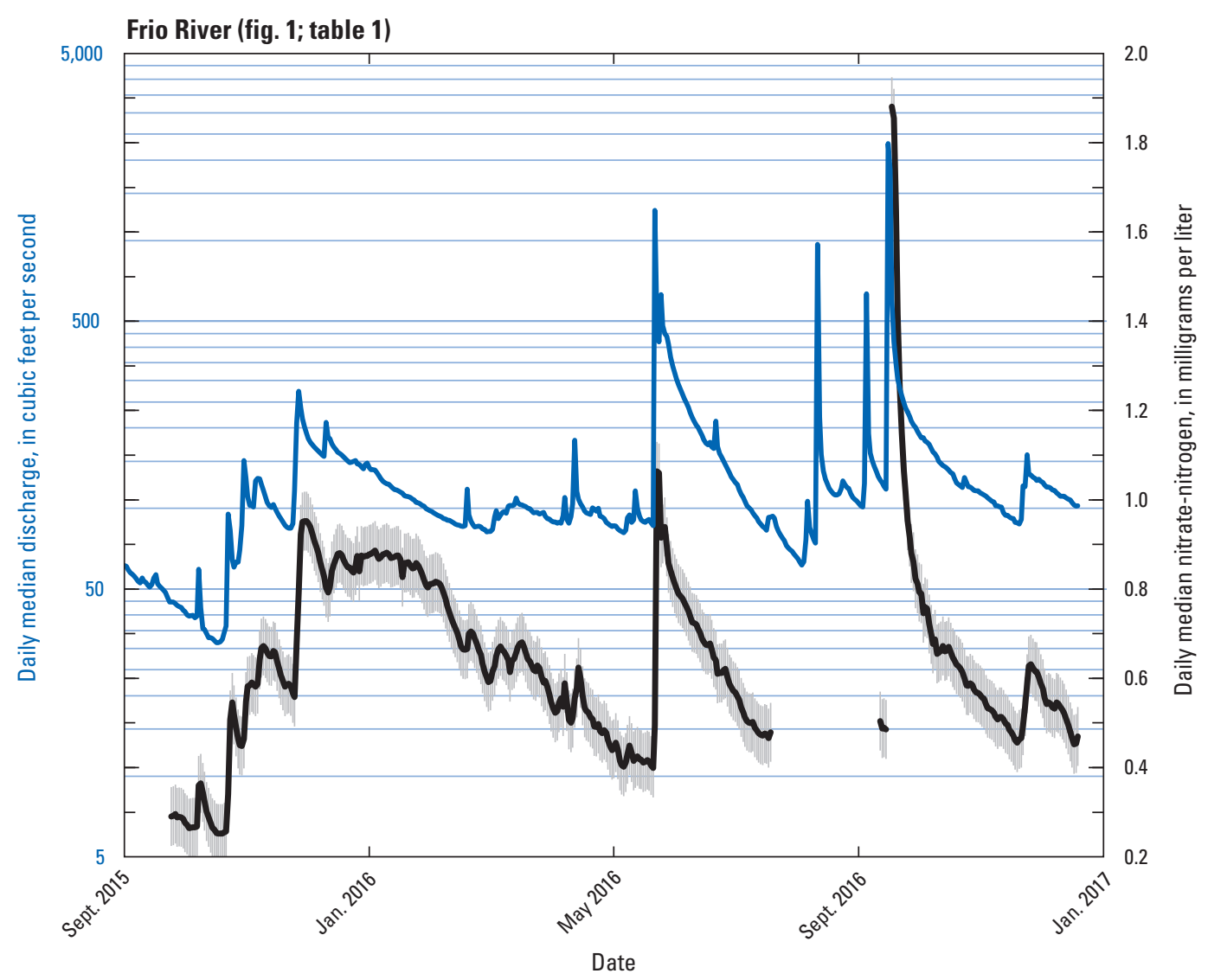

EXPLANATION

Daily median nitrate-nitrogen-Gray shading indicates 95 percent confidence interval Daily median discharge

Figure 10. Daily median discharge and daily median nitrate-nitrogen concentration at Frio River (station 0819500), San Antonio segment of the Edwards aquifer, south-central Texas, September 2015-December 2016. The shaded gray area associated with nitratenitrogen concentrations represents the probability range in error (plus or minus 0.07 milligrams per liter) with a 95 percent confidence interval. Gaps in the continuous record indicate missing data. 


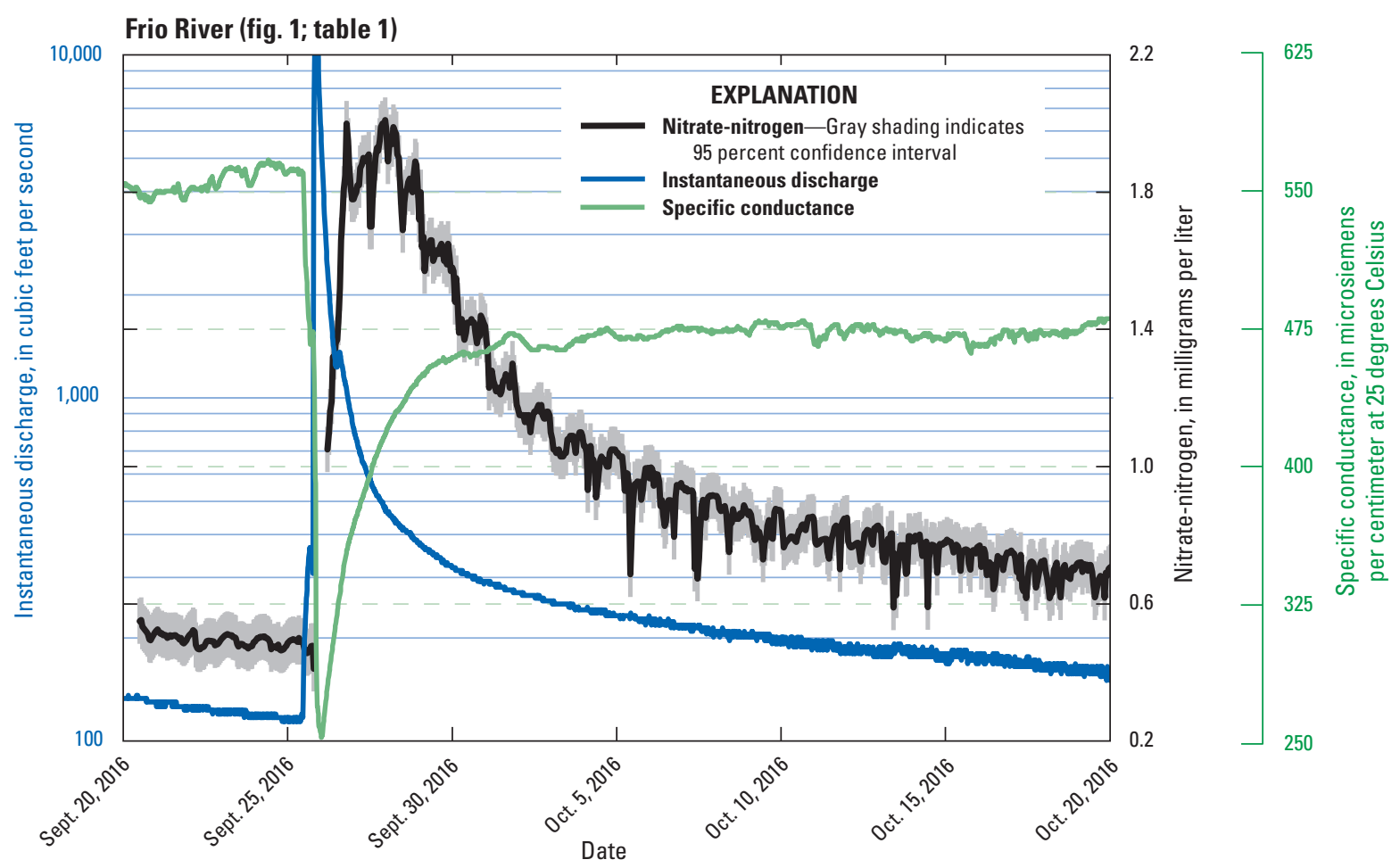

Figure 11. Instantaneous discharge, nitrate-nitrogen concentration, and specific conductance for a single stormwater-runoff event at Frio River (station 0819500), San Antonio segment of the Edwards aquifer, south-central Texas, September 20, 2016-0ctober 20, 2016. The shaded gray area associated with nitrate-nitrogen concentrations represents the probability range in error (plus or minus 0.07 milligrams per liter) with a 95 percent confidence interval. Gaps in the continuous record indicate missing data.

the recession that follows peak discharge, attributing this pattern to $\mathrm{NO}_{3}$ mobilization from soils. As the discharge peak at the Frio River receded, $\mathrm{NO}_{3}$ concentrations gradually declined to near, although somewhat higher than, base-flow values prior to the event (fig. 10).

\section{Unconfined Rural Groundwater}

Continuous $\mathrm{NO}_{3}$ monitoring at Seco well began in July 2014, during the dry period when WLA was gradually declining (fig. 12A). Several small recharge events (less than 2 in. of rainfall) between July 2014 and March 2015 resulted in small (less than $3 \mathrm{ft}$ ) increases in WLA and corresponding small but rapid increases and decreases in $\mathrm{NO}_{3}$ concentration. Following the onset of more frequent and larger rain events during the wet period-including multiple events in spring 2015, winter 2015, and spring 2016- $\mathrm{NO}_{3}$ concentration increased a small amount (approximately $0.15 \mathrm{mg} / \mathrm{L}$ ) and then remained at that higher concentration. The total variability in $\mathrm{NO}_{3}$ at Seco well was relatively small, ranging from about 1.0 to $1.3 \mathrm{mg} / \mathrm{L}$. Although the difference in $\mathrm{NO}_{3}$ concentration between the dry period and the wet period was small, it is distinguishable outside of the $\mathrm{NO}_{3}$ sensor's precision of plus or minus $0.07 \mathrm{mg} / \mathrm{L}$ (Opsahl and others, 2017), indicating that $\mathrm{NO}_{3}$ concentrations at this site responded to longer term changes in hydrologic conditions.

\section{Unconfined Urban Groundwater}

As at Seco well, $\mathrm{NO}_{3}$ continuous monitoring at Parkwood well began during the dry period (September 2014), and the transition from the dry to wet period showed varying responses to changing hydrologic conditions (fig. 12B). Ambient $\mathrm{NO}_{3}$ concentrations at Parkwood well were initially high (about $2.7 \mathrm{mg} / \mathrm{L}$ ) in comparison to Seco well (about $1.0 \mathrm{mg} / \mathrm{L}$ ), as was the overall variability in $\mathrm{NO}_{3}$ concentration at Parkwood well (about 0.8 to $3.3 \mathrm{mg} / \mathrm{L}$ ) in comparison to Seco well (about 1.0 to $1.3 \mathrm{mg} / \mathrm{L}$ ) (fig. $12 A, B$ ). $\mathrm{NO}_{3}$ concentrations at Parkwood well were relatively constant during the dry period, except for a small event in November 2014 - several inches of rain and corresponding recharge resulted in a small increase in WLA and a corresponding slight decrease in $\mathrm{NO}_{3}$ concentration. In response to frequent rainfall during the transition to the wet period in spring 2015, WLA rose rapidly by about $40 \mathrm{ft}$ over a period of a few days, and concurrently, $\mathrm{NO}_{3}$ concentration decreased from about $2.7 \mathrm{mg} / \mathrm{L}$ to less than $1 \mathrm{mg} / \mathrm{L}$. A similar pattern of rapid WLA increase and corresponding $\mathrm{NO}_{3}$ concentration decrease occurred during several subsequent rainfall and recharge events during the remainder of 2015 and in 2016. After each of these events, as WLA stabilized at a new and higher value, $\mathrm{NO}_{3}$ concentrations typically returned to a consistent ambient concentration of around $2.7 \mathrm{mg} / \mathrm{L}$. These rapid rises in WLA 
A
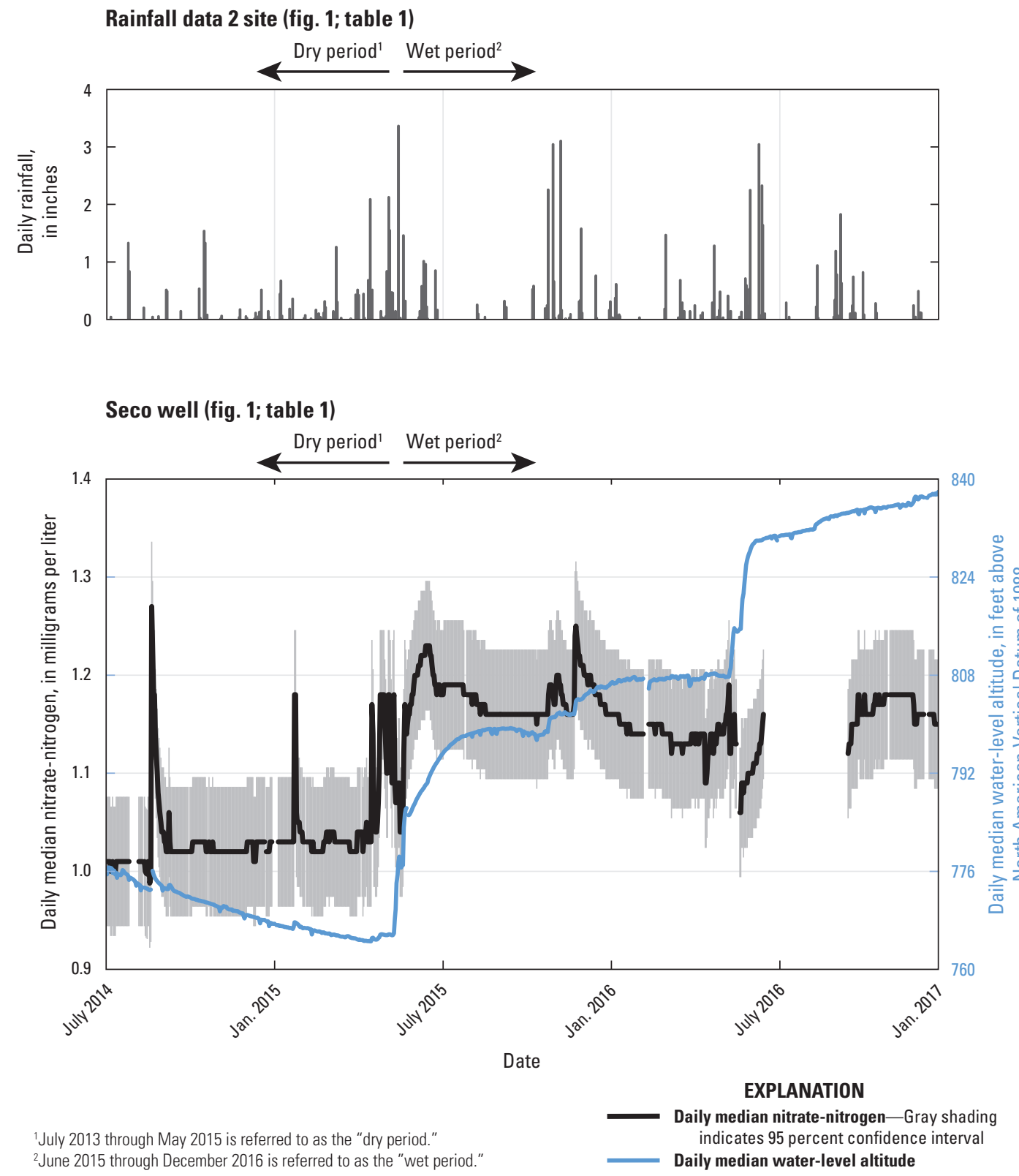

Figure 12. Rainfall, daily median water-level altitude, and daily median nitrate-nitrogen for A, Seco well, July 2014-December 2016, and B, Parkwood well, September 2014-December 2016, San Antonio segment of the Edwards aquifer, south-central Texas. The shaded gray area associated with nitrate-nitrogen concentrations represents the probability range in error (plus or minus 0.07 milligrams per liter) with a 95 percent confidence interval. Gaps in the continuous record indicate missing data. 
Rainfall data 1 site (fig. 1; table 1)

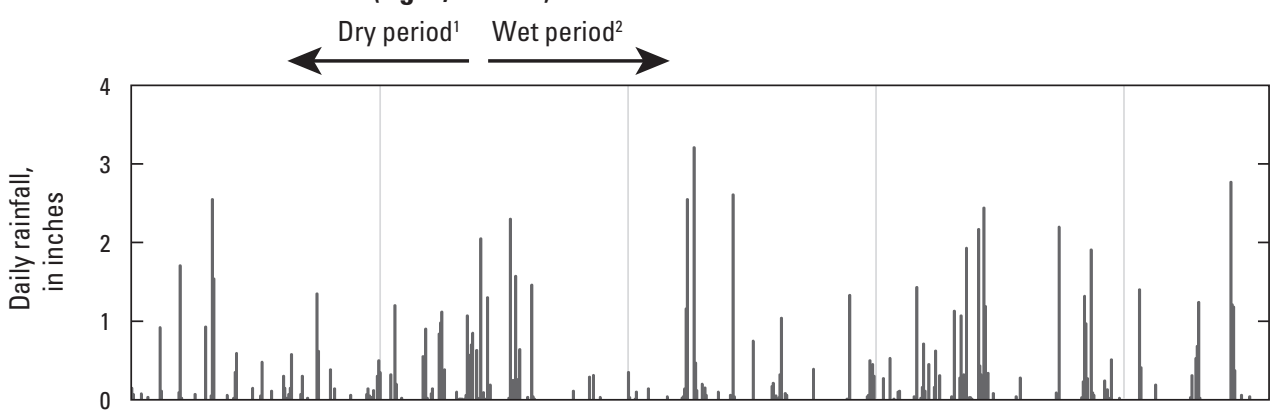

Parkwood well (fig. 1; table 1)

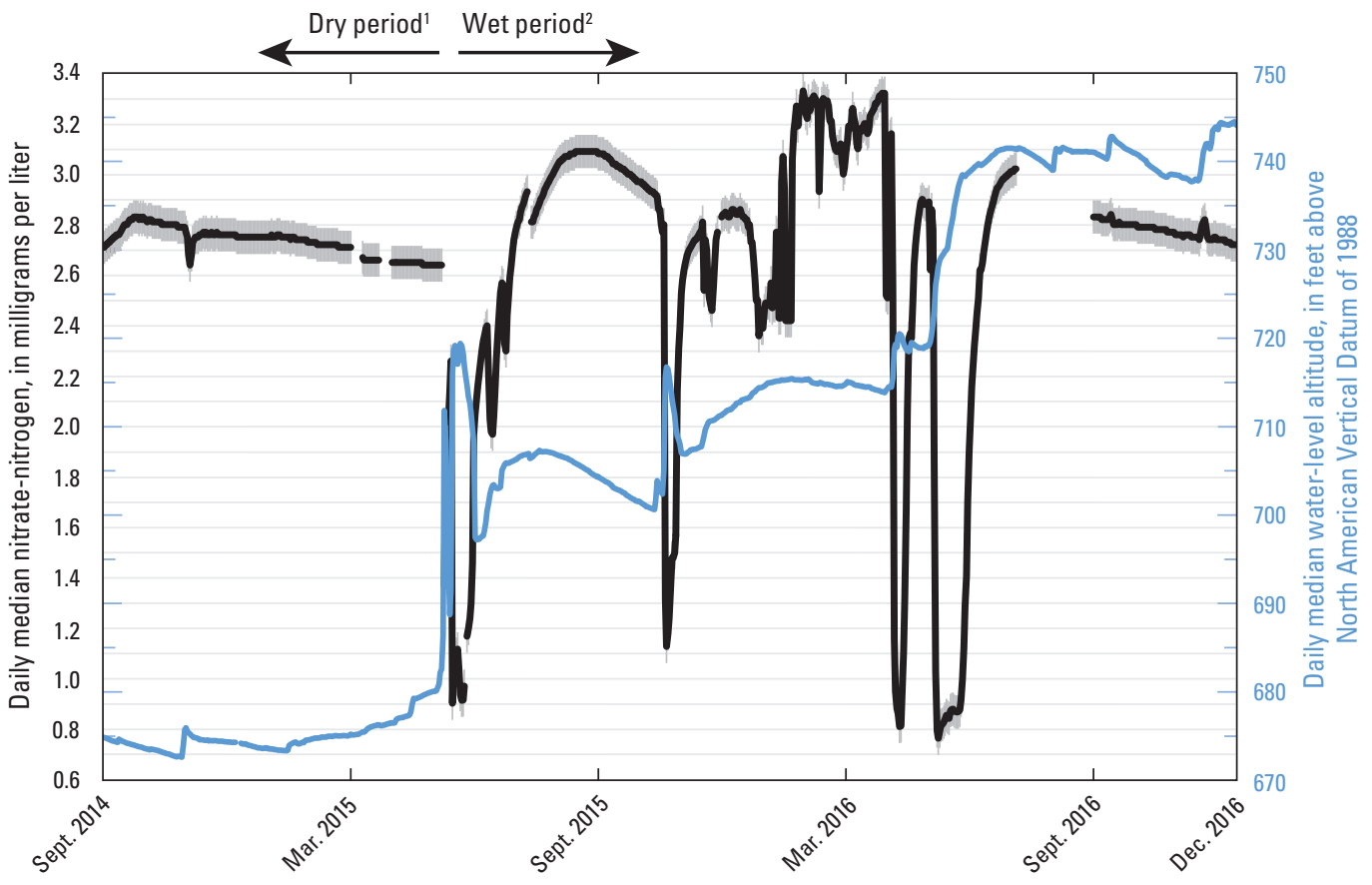

Date

EXPLANATION

'July 2013 through May 2015 is referred to as the "dry period."

2June 2015 through December 2016 is referred to as the "wet period."

Daily median nitrate-nitrogen-Gray shading indicates 95 percent confidence interval Daily median water-level altitude

Figure 12. Rainfall, daily median water-level altitude, and daily median nitrate-nitrogen for A, Seco well, July 2014-December 2016, and B, Parkwood well, September 2014-December 2016, San Antonio segment of the Edwards aquifer, south-central Texas. The shaded gray area associated with nitrate-nitrogen concentrations represents the probability range in error (plus or minus 0.07 milligrams per liter) with a 95 percent confidence interval. Gaps in the continuous record indicate missing data.-Continued 
and sharp decreases in $\mathrm{NO}_{3}$ concentration are hypothesized to result from mixing of groundwater with a rapid influx of more dilute, low- $\mathrm{NO}_{3}$ recharge water. $\mathrm{NO}_{3}$ concentrations at Helotes Creek, which might represent a suitable surrogate for urban streams recharging in the area, ranged from 0.30 to $1.54 \mathrm{mg} / \mathrm{L}$ (table 8). Mixing between ambient groundwater and lower $\mathrm{NO}_{3}$ recharging stormwater runoff derived directly from recharge streams such as Helotes Creek can account for the rapid and short-term dilution of ambient water at Parkwood well.

\section{Distinguishing Nitrate Sources}

Measuring the isotopes $\delta^{15} \mathrm{~N}-\mathrm{NO}_{3}$ and $\delta^{18} \mathrm{O}-\mathrm{NO}_{3}$ found in rainfall, surface-water, and groundwater samples provided insights into the sources contributing $\mathrm{NO}_{3}$ to the Edwards aquifer. Rainfall samples had characteristically low $\delta^{15} \mathrm{~N}^{-\mathrm{NO}_{3}}$ and high $\delta^{18} \mathrm{O}-\mathrm{NO}_{3}$ values (fig. $13 \mathrm{~A}$ ), which were within the range of previously published values for rainfall in this region (Lambert and others, 2017). Surface-water samples had a large range of $\delta^{15} \mathrm{~N}_{-} \mathrm{NO}_{3}$ and $\delta^{18} \mathrm{O}-\mathrm{NO}_{3}$ values, likely reflecting varying contributions of $\mathrm{NO}_{3}$ from different possible sources, including rainfall, inorganic fertilizers, human and animal waste, and natural soil $\mathrm{NO}_{3}$ (fig. 13A). Most of the $\delta^{15} \mathrm{~N}^{-\mathrm{NO}_{3}}$ values measured in surface-water samples were less than 8 per mil, which indicates that little to no $\mathrm{NO}_{3}$ was likely derived from human or animal waste, which is characterized by relatively high $\delta^{15} \mathrm{~N}^{-\mathrm{NO}_{3}}$ values

(fig. 13A). Five surface-water samples had $\delta^{15} \mathrm{~N}^{-\mathrm{NO}_{3}}$ values less than 5 per mil and $\delta^{18} \mathrm{O}-\mathrm{NO}_{3}$ values greater than 10 per mil (fig. 13B), which is consistent with mixing with a component of runoff from recent rainfall. Contributions to surface water from other low $\delta^{15} \mathrm{~N}_{-N O}$ sources, however, such as inorganic fertilizer (fig. 13A), cannot be ruled out on the basis of only isotopes. Groundwater samples generally have a much smaller range of isotopic values at each site, indicating less temporal variability at groundwater sites relative to surface water and rainfall, and results for each groundwater site tend to cluster in a distinct grouping (fig. 13B). One exception was a subset of samples from Parkwood well that had the lowest $\delta^{15} \mathrm{~N}_{-} \mathrm{NO}_{3}$ values for this site (less than 7 per mil) (fig. 13B). This subset of samples was collected in response to rainfall and recharge events and, based on $\mathrm{SC}$ changes (fig. $5 B$ ), reflect mixing with a component of recent recharge water; the low $\delta^{15} \mathrm{~N}^{-\mathrm{NO}_{3}}$ values for these samples correspond with low $\mathrm{NO}_{3}$ concentrations described in the "Nutrient Geochemistry" section of this report.
Isotopic values of $\mathrm{NO}_{3}$ in combination with $\mathrm{NO}_{3}$ concentrations can provide insight into $\mathrm{NO}_{3}$ sources (Kendall and others, 2014; Musgrove and others, 2016) (fig. 14). Among the groundwater sites, the small range of $\delta^{15} \mathrm{~N}^{-\mathrm{NO}_{3}}$ values for Seco well (4.33 to 5.75 per mil) and corresponding low $\mathrm{NO}_{3}$ concentration (median $\mathrm{NO}_{3}$ of $1.04 \mathrm{mg} / \mathrm{L}$ ) (table 9) indicate predominantly natural, soil-derived $\mathrm{NO}_{3}$ with little contribution from anthropogenic sources. In contrast, Parkwood well (with the exception of samples collected in response to recharge events) had the highest $\delta^{15} \mathrm{~N}^{-\mathrm{NO}_{3}}$ values (median of 7.69 per mil) and $\mathrm{NO}_{3}$ concentrations (median of $2.65 \mathrm{mg} / \mathrm{L}$ ) (table 9), which is consistent with mixing with a component of $\mathrm{NO}_{3}$ from human or animal waste sources. Other groundwater sites were intermediate in their $\mathrm{NO}_{3}$ isotopic and concentration values, with higher $\delta^{15} \mathrm{~N}_{-} \mathrm{NO}_{3}$ values corresponding to higher $\mathrm{NO}_{3}$ concentrations. On the basis of the observed patterns among wells (fig. 14), higher $\delta^{15} \mathrm{~N}^{-\mathrm{NO}_{3}}$ values and $\mathrm{NO}_{3}$ concentrations indicate a larger component of $\mathrm{NO}_{3}$ sourced from human and animal waste. Samples from Zarzamora well had somewhat higher $\delta^{15} \mathrm{~N}_{-} \mathrm{NO}_{3}$ values than the general trend, which also might indicate a proportionally larger local component of $\mathrm{NO}_{3}$ derived from human and animal waste in comparison to the other confined groundwater sites.

\section{Factors Affecting Nitrate}

An examination of the concentration patterns of individual $\mathrm{N}$ species helps to explain controls on $\mathrm{NO}_{3}$ concentrations throughout the Edwards aquifer system. Median values indicate that $\mathrm{NO}_{3}$ in rainfall is generally low (median values for both rural and urban rainfall around $0.1 \mathrm{mg} / \mathrm{L}$ ) (table 7), is higher in surface water (median values ranging from 0.25 to $0.56 \mathrm{mg} / \mathrm{L}$ ) (table 8 ), and is highest in groundwater (median values ranging from 1.04 to $2.65 \mathrm{mg} / \mathrm{L}$ ) (table 9). The much lower median $\mathrm{NO}_{3}$ concentrations in rainfall (table 7) relative to surface water (table 8) indicate that $\mathrm{NO}_{3}$ in rainfall is generally a variable but relatively minor direct contributor of $\mathrm{NO}_{3}$ to groundwater. In contrast, $\mathrm{NH}_{4}$ and DON in rainfall contribute to the input of total $\mathrm{N}$ to the aquifer. Concentrations of $\mathrm{NH}_{4}$ were generally higher in rainfall than in surface water, and $\mathrm{NH}_{4}$ was rarely detected in groundwater (fig. 15A). In contrast, DON concentrations were generally lower in rainfall and generally higher in surface water (fig. 15B). DON concentrations in surface water are likely attributable to mobilization of DON from soils into the streams during storm events (Campbell and others, 2000; Cooper and others, 2007). However, like $\mathrm{NH}_{4}$, DON was detected in only a few groundwater samples. 


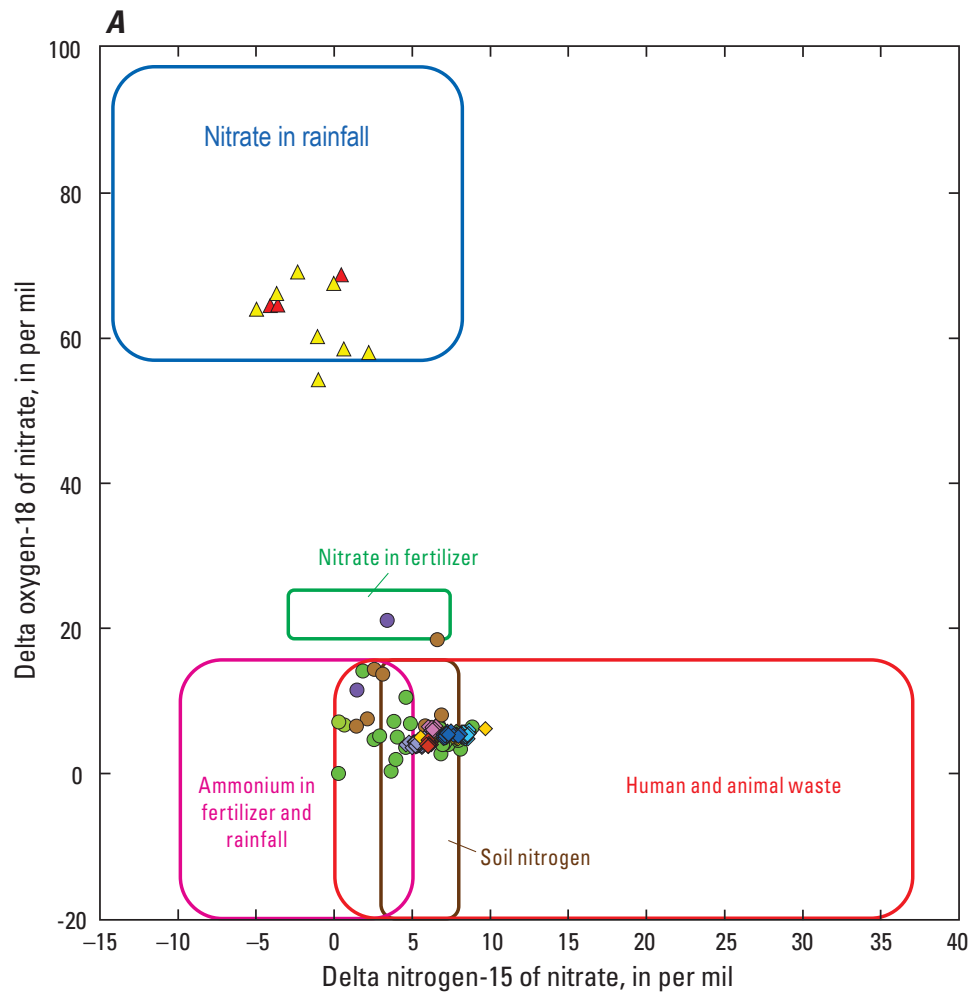

\section{EXPLANATION}

Sample, by site (fig. 1; table 1)

$\Delta$ Rural rainfall-Sample collected at Frio River site

$\triangle$ Urban rainfall-Sample collected at Urban rainfall 1 , Urban rainfall 2 , and Urban rainfall 3

- Frio River

- Seco Creek

Culebra Creek

- Helotes Creek

$\diamond$ Seco well

$\diamond$ Parkwood well

$\diamond$ Shavano well

$\diamond$ Zarzamora well

$\diamond$ Turtle well

$\diamond$ Mission well

- Comal 1 spring

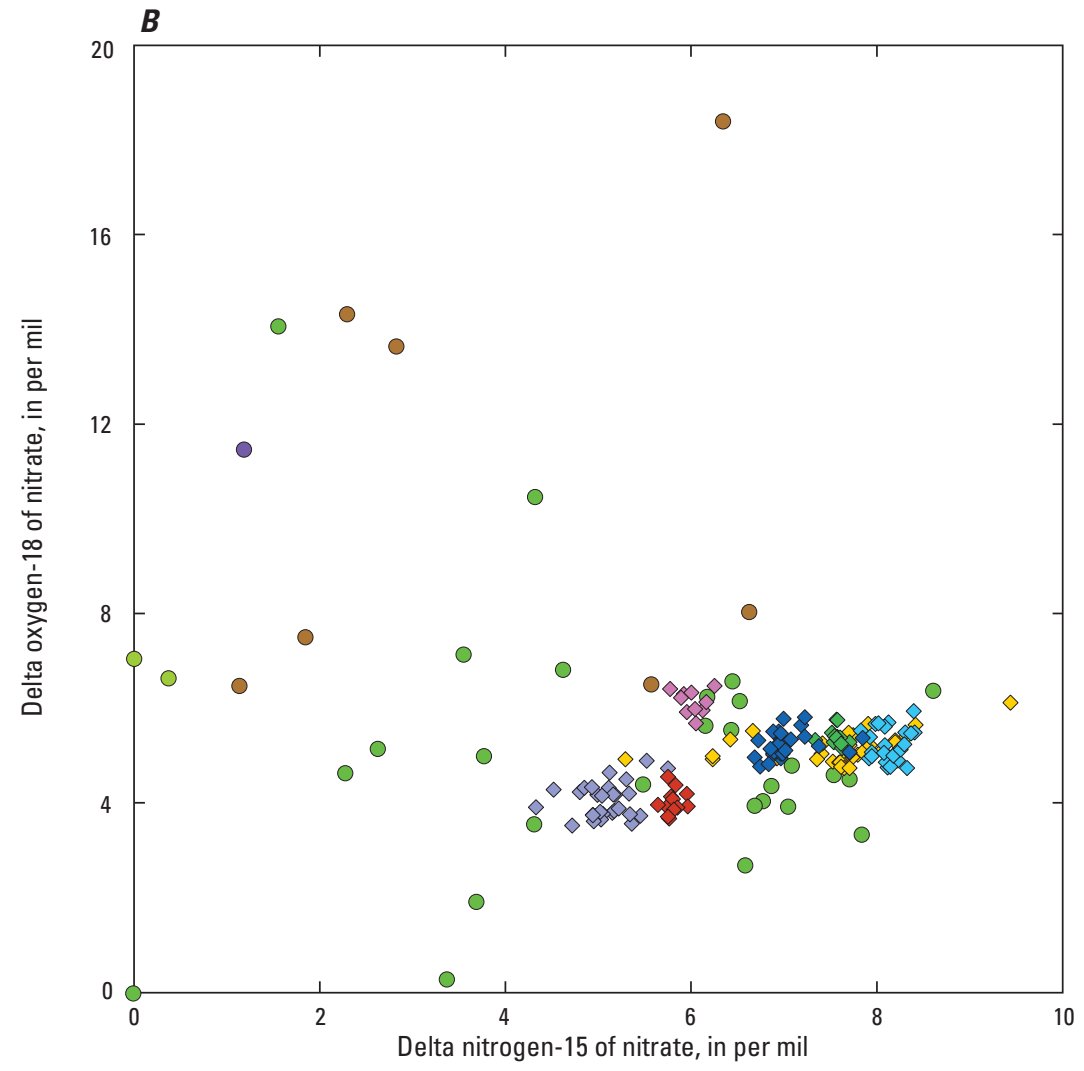

EXPLANATION

Sample, by site (fig. 1; table 1)

- Frio River

- Seco Creek

- Culebra Creek

- Helotes Creek

$\diamond$ Secowell

$\diamond$ Parkwood well

$\diamond$ Shavano well

$\diamond$ Zarzamora well

$\diamond \quad$ Turtle well

$\checkmark$ Mission well

$\diamond \quad$ Comal 1 spring

Figure 13. Stable nitrogen and oxygen isotopes of nitrate (delta nitrogen- 15 of nitrate $\left[\delta^{15} \mathrm{~N}\right.$-nitrate] and delta oxygen-18 of nitrate $\left[\delta^{18} 0\right.$-nitrate]) measured in water samples collected from rainfall, surface-water, and groundwater sampling sites in the San Antonio segment of the Edwards aquifer, south-central Texas, 2011-16, for $A$, all samples within the full range of $\delta^{15} \mathrm{~N}$-nitrate and $\delta^{18} 0$-nitrate values reported in this study and $B$, samples within a $\delta^{15} \mathrm{~N}$-nitrate range between 0 and 10 per mil and a $\delta^{18} 0$-nitrate range between 0 and 20 per mil. Boxes show the typical range of nitrate sources, modified from Kendall and others (2014). Ranges do not reflect specific south-central Texas sources but a compilation of measured values from numerous studies. 


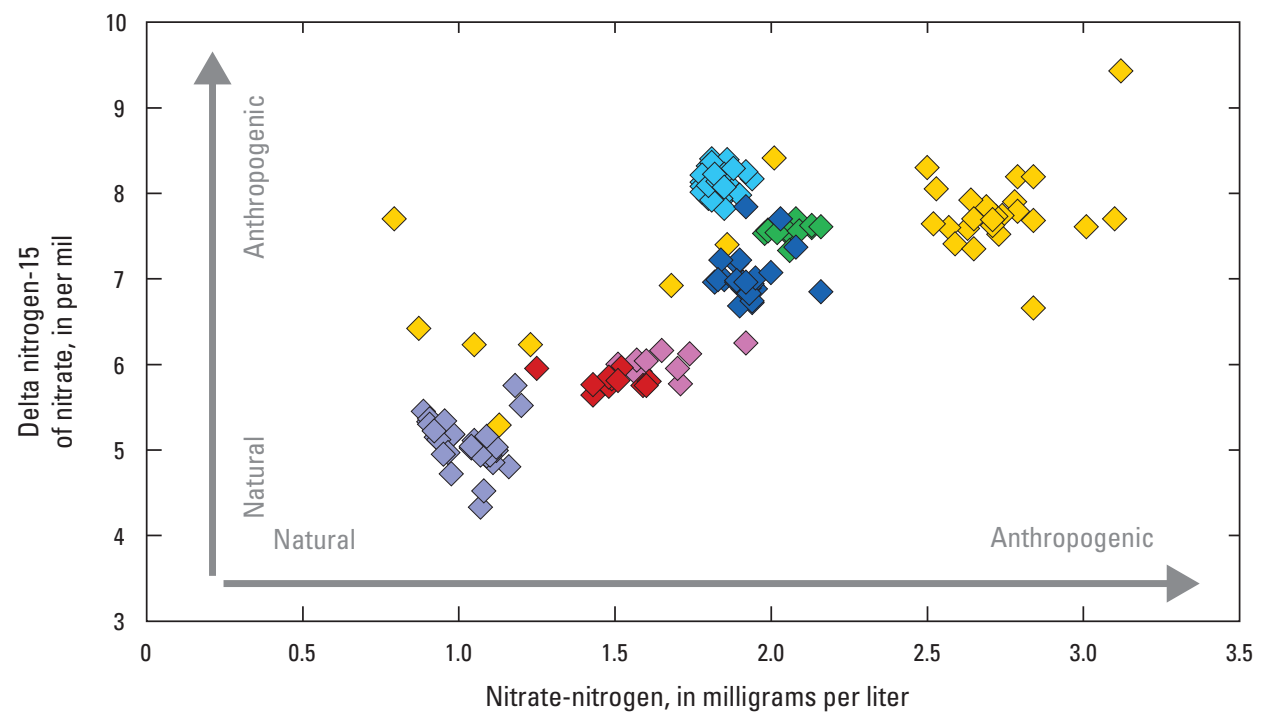

EXPLANATION

Groundwater sample, by site (fig. 1; table 1)

$\diamond$ Secowell

$\diamond$ Parkwood well

$\checkmark$ Shavano well

$\diamond$ Zarzamora well

$\diamond$ Turtle well

- Mission well

Comal 1 spring

Figure 14. Stable nitrogen isotopes of nitrate (delta nitrogen-15 of nitrate [ $\delta^{15} \mathrm{~N}$-nitrate]) values versus nitrate-nitrogen concentration measured in groundwater water samples collected from sampling sites in the San Antonio segment of the Edwards aquifer, southcentral Texas, 2013-16. Arrows depict a progression of nitrate-nitrogen from minimally affected (natural) to more heavily influenced by anthropogenic sources.
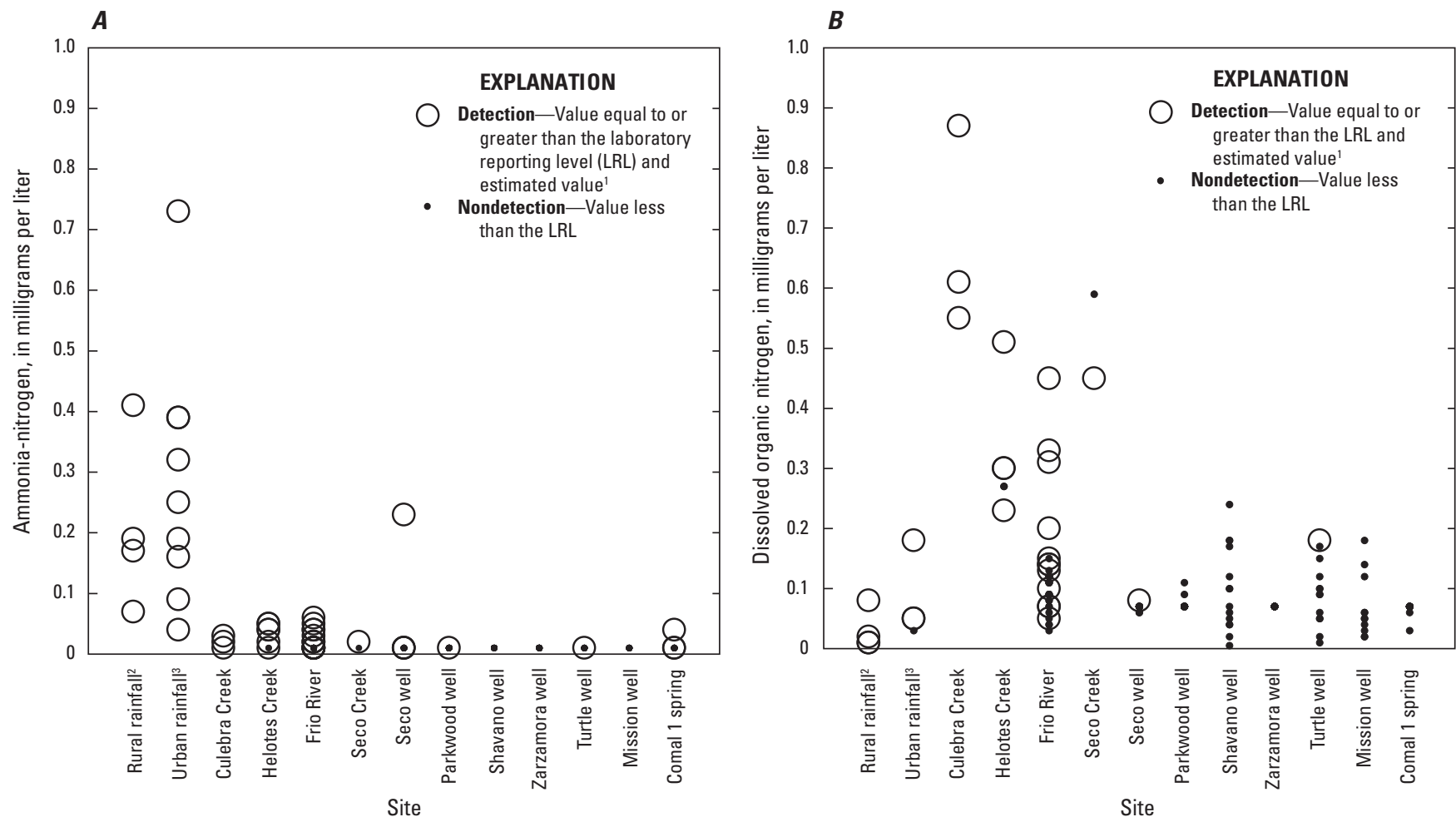

${ }^{1} \mathrm{~A}$ constituent concentration is considered estimated by the laboratory when results are greater than the long-term method detection level (LT-MDL) and less than the LRL; that is, a detection is considered likely, but quantification is considered questionable. The remark code of "E" (estimated) is assigned by the laboratory for these values (Childress and others, 1999). ${ }^{2}$ Rural rainfall sample collected at Frio River (fig. 1; table 1).

${ }^{3}$ Urban rainfall sample collected at Urban rainfall 1, Urban rainfall 2, and Urban rainfall 3 (fig. 1; table 1).

Figure 15. Concentrations of $A$, ammonia-nitrogen and $B$, dissolved organic nitrogen measured in water samples collected from sampling sites in the San Antonio segment of the Edwards aquifer, south-central Texas, 2010-16. Samples with nondetections are plotted at the laboratory reporting level. 
The absence or near absence of $\mathrm{NH}_{4}$ and DON in groundwater might result from their oxidation to $\mathrm{NO}_{3}$ by nitrification, a microbial process common in soils and aquatic environments (Kendall and others, 2007). Nitrification might occur subaqueously if DON and $\mathrm{NH}_{4}$ reach the saturated zone during periods of rapid recharge and oxygenated conditions are present (DeSimone and Howes, 1998), as occurs in karst aquifers. This process has been previously proposed for the Edwards aquifer, where nitrification of DON and $\mathrm{NH}_{4}$ can account for the increase in $\mathrm{NO}_{3}$ observed in the aquifer relative to recharging surface water (Musgrove and others, 2016). In the present study, the decrease in concentrations of DON and $\mathrm{NH}_{4}$ from rainfall to surface-water recharge to groundwater is consistent with transformation by nitrification (fig. 15A). Although there are processes other than nitrification that transform $\mathrm{NH}_{4}$ and DON, such as biological uptake, the relation between the sum of $\mathrm{NH}_{4}$ and $\mathrm{DON}$ versus $\mathrm{NO}_{3}$ concentrations (fig. 16) indicates nitrification as a plausible process occurring in the aquifer. The $\delta^{15} \mathrm{~N}_{-} \mathrm{NO}_{3}$ data show a progression from rainfall (median $\delta^{15} \mathrm{~N}_{-} \mathrm{NO}_{3}=-3.91$ to -1.33 ) (table 7) to surface water (median $\delta^{15} \mathrm{~N}-\mathrm{NO}_{3}=0.20$ to 6.30) (table 8) to groundwater (median $\delta^{15} \mathrm{~N}^{-\mathrm{NO}_{3}}=5.05$ to 8.13) (table 9), which provides further support for the hypothesis that $\mathrm{NH}_{4}$ and DON are transformed to $\mathrm{NO}_{3}$ as water recharges the aquifer. The increase in $\delta^{15} \mathrm{~N}_{-} \mathrm{NO}_{3}$ values is consistent with progressively higher $\delta^{15} \mathrm{~N}^{-\mathrm{NO}_{3}}$ values that were measured during conversion of $\mathrm{NH}_{4}$ to $\mathrm{NO}_{3}$ in soils (Hübner, 1986; Kendall, 1998). Furthermore, Musgrove and others (2016) reported a similar increase in $\delta^{15} \mathrm{~N}^{-\mathrm{NO}_{3}}$ values during the transformation of $\mathrm{NH}_{4}$ and $\mathrm{DON}$ to $\mathrm{NO}_{3}$ in the Edwards aquifer.

\section{Nitrogen Inputs and Cycling in the Edwards Aquifer}

An analysis of $\mathrm{NO}_{3}$ concentrations, $\delta^{15} \mathrm{~N}^{-\mathrm{NO}_{3}}$ values, and additional $\mathrm{N}$ species that affect $\mathrm{NO}_{3}$ concentrations (that is, $\mathrm{NH}_{4}$ and DON) is necessary for distinguishing between rural and urban $\mathrm{N}$ sources and estimating the magnitude of anthropogenic $\mathrm{NO}_{3}$ source contributions to the Edwards aquifer (fig. 14). Results of this study indicate that there were different sources of $\mathrm{NO}_{3}$ in rural and urban areas and that anthropogenic activities contribute to higher $\mathrm{NO}_{3}$ concentrations in groundwater in the urban San Antonio area. The differences between $\mathrm{NO}_{3}$ inputs in rural and urban groundwater are illustrated by a comparison of continuous $\mathrm{NO}_{3}$ monitoring and $\delta^{15} \mathrm{~N}^{-\mathrm{NO}_{3}}$ results at the rural unconfined Seco well and the urban unconfined Parkwood well in response to recharge events. At the rural unconfined well, the median $\mathrm{NO}_{3}$ concentration was relatively low $(1.04 \mathrm{mg} / \mathrm{L})$ (table 9), and changes in $\mathrm{NO}_{3}$ concentration in response to recharge events were small, indicating little difference in $\mathrm{NO}_{3}$ concentration between ambient groundwater and recent surface-water recharge (fig. 12A). Furthermore, the $\delta^{15} \mathrm{~N}_{-} \mathrm{NO}_{3}$ values at the rural Seco well were consistent with natural soil $\mathrm{NO}_{3}$ sources (fig. 13). In contrast, at Parkwood well, the median $\mathrm{NO}_{3}$ concentration was more than twice as high $(2.65$ $\mathrm{mg} / \mathrm{L}$ ) (table 9), and $\mathrm{NO}_{3}$ concentration notably decreased in response to surface-water recharge (fig. 12B). These results indicate that locally ambient groundwater $\mathrm{NO}_{3}$ is diluted by lower $\mathrm{NO}_{3}$ recharge water (fig. $12 B$ ). $\delta^{15} \mathrm{~N}_{3} \mathrm{NO}_{3}$ values measured in ambient groundwater samples were consistent with a component of human and animal waste as a source of the $\mathrm{NO}_{3}$, whereas $\delta^{15} \mathrm{~N}-\mathrm{NO}_{3}$ values measured in stormresponse samples were indicative of a more natural, soilderived $\mathrm{NO}_{3}$ source within the urban setting. As the recharge pulse moved through the aquifer, $\mathrm{NO}_{3}$ concentrations returned to the higher ambient concentrations typical of this site. In the urban San Antonio area, possible sources of higher $\delta^{15} \mathrm{~N}^{-\mathrm{NO}_{3}}$ values are treated wastewater, wastewater from septic systems, leaky sewer pipes, or other as yet unidentified waste sources (Dubrovsky and others, 2010).

Natural background $\mathrm{NO}_{3}$ concentrations in groundwater nationally and within the Edwards aquifer have been previously estimated to be about $1 \mathrm{mg} / \mathrm{L}$ (Dubrovsky and others, 2010; Musgrove and others, 2016). The ambient $\mathrm{NO}_{3}$ concentration of about $1 \mathrm{mg} / \mathrm{L}$ at the rural Seco well therefore is consistent with the hypothesis that the $\mathrm{NO}_{3}$ at Seco well is predominantly from natural rather than anthropogenic sources. In contrast, $\mathrm{NO}_{3}$ concentrations at Parkwood well (maximum $\mathrm{NO}_{3}$ of $3.12 \mathrm{mg} / \mathrm{L}$ ) (table 9) indicate that about two-thirds of the $\mathrm{NO}_{3}$ in groundwater samples collected for this study might result from anthropogenic $\mathrm{NO}_{3}$ sources, assuming that $1 \mathrm{mg} / \mathrm{L}$ is the natural background concentration and the remainder (2.12 $\mathrm{mg} / \mathrm{L}$ ) is anthropogenic. Although groundwater sites sampled for this study were selected to be representative of a range of water-quality conditions and potential anthropogenic sources, higher $\mathrm{NO}_{3}$ concentrations have been measured at other groundwater wells in the aquifer (Musgrove and others, 2010), and thus the proportion of anthropogenic $\mathrm{NO}_{3}$ might be higher at some locations.

Natural biogeochemical processes in the aquifer affect the fate and transport of all $\mathrm{N}$ species and play a role in determining the distribution of $\mathrm{NO}_{3}$ concentrations throughout the aquifer. Loss of $\mathrm{NO}_{3}$ through denitrification, a process that occurs under anoxic conditions, is unlikely to occur in the oxic conditions of the Edwards aquifer. However, as discussed previously, the process of nitrification of DON and $\mathrm{NH}_{4}$ from rainwater and surface water might be an important but previously unaccounted source of $\mathrm{NO}_{3}$ to Edwards aquifer groundwater, as evidenced by the decrease in DON plus $\mathrm{NH}_{4}$ concentrations from rainfall to surface water to groundwater and the corresponding increase in $\mathrm{NO}_{3}$ concentration (fig. 16). Characterization of sources, fate, and transport of $\mathrm{NO}_{3}$ in the San Antonio segment of the Edwards aquifer therefore requires consideration of all $\mathrm{N}$ species. 


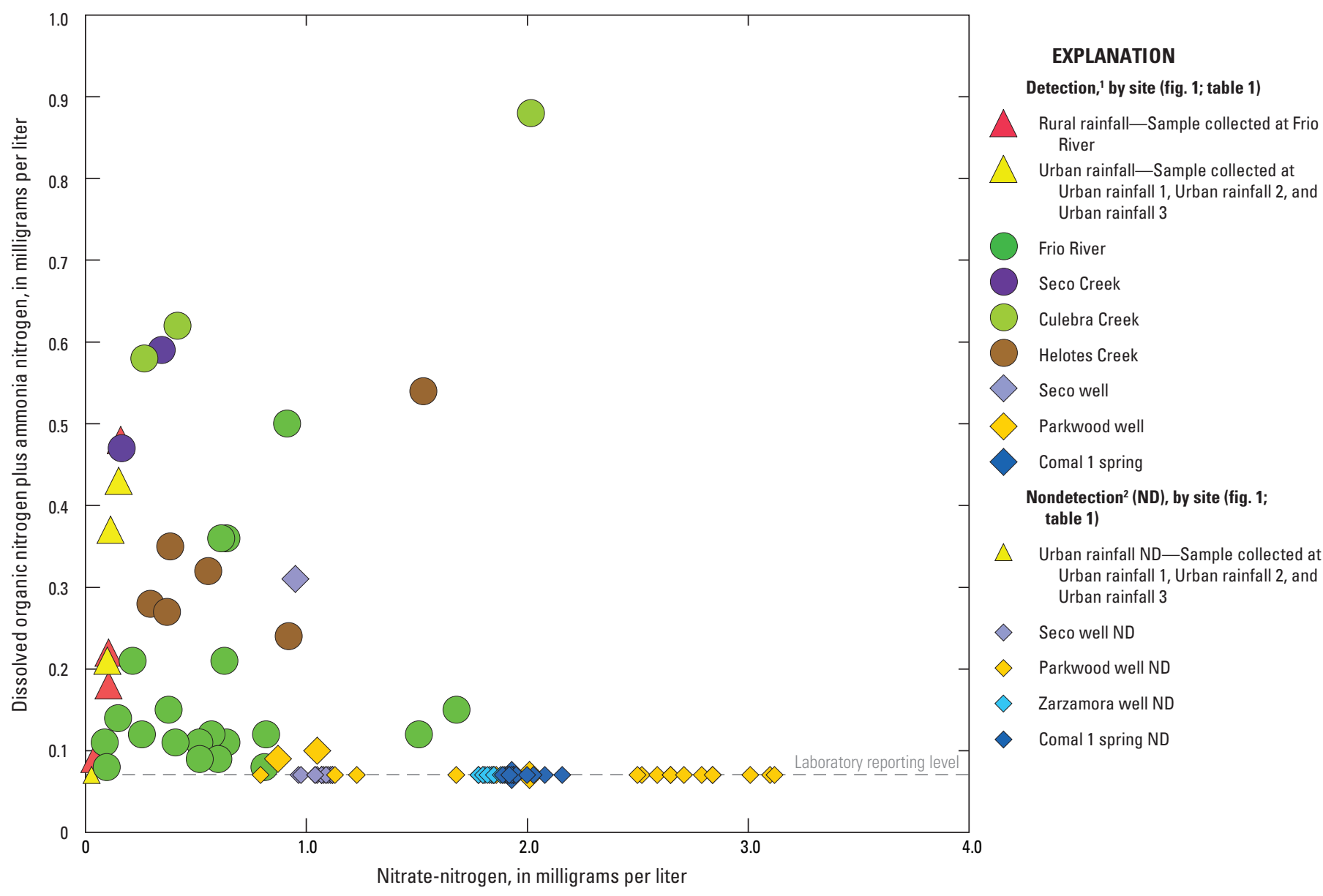

'Detections consist of values greater than or equal to the laboratory reporting level (LRL) and estimated values. A constituent concentration is considered estimated by the laboratory when results are greater than the long-term method detection level (LT-MDL) and less than the LRL; that is, a detection is considered likely, but quantification is considered questionable. The remark code of " $E$ " (estimated) is assigned by the laboratory for these values (Childress and others, 1999).

${ }^{2}$ Nondetections are values reported for constituents that were analyzed for and were present at concentrations below the LRL and not quantified or were not present at all. For display purposes only, nondetections are depicted on this graph at the concentration that defines the LRL.

Figure 16. The sum of dissolved organic nitrogen and ammonia-nitrogen concentration versus nitrate-nitrogen concentration measured in water samples collected from sampling sites in the San Antonio segment of the Edwards aquifer, south-central Texas, 2010-16.

\section{Pesticide Geochemistry}

\section{Rainfall}

At least 1 pesticide was detected in each of the 11 rainfall samples analyzed (table 10). A total of 9 pesticides (6 herbicides and 3 insecticides) were detected. The herbicide dimethyl tetrachloroterephthalate (dacthal, abbreviated as DCPA) was detected the most frequently (8 of 11 samples; 73 percent), followed by the herbicides metolachlor and atrazine (7 of 11 samples; 64 percent). The DEA to atrazine ratio (DAR) is often used to evaluate the extent of atrazine degradation in the environment (Adams and Thurman, 1991; Thurman and Fallon, 1996; Townsend and Young, 2000). The DAR in rainfall was $0.25-1.10$ (median 0.53 ) for the 5 samples of rainfall in which both DEA and atrazine were detected (Opsahl and others, 2018), in the range typical for rainfall for the central United States (Scribner and others, 2005). Rainfall typically has a higher DAR than surface water because of the photodegradation of atrazine to DEA in the atmosphere (Thurman and Cromwell, 2000). Concentrations of pesticides in rainfall were low-the maximum concentration measured was 0.051 micrograms per liter $(\mu \mathrm{g} / \mathrm{L})($ atrazine at Urban rainfall 2 site) (table 10). 
Table 10. Summary of pesticide concentrations measured in rainfall samples collected from Frio River and Urban rainfall 1, 2, and 3 in the San Antonio segment of the Edwards aquifer, south-central Texas, 2014-16.

[Only those pesticides that were detected in at least one sample are shown. DEA, deethylatrazine; CIAT, 2-Chloro-4-isopropylamino-6-amino-s-triazine; $\mu \mathrm{g} / \mathrm{L}$, microgram per liter; DCPA (dacthal), dimethyl tetrachloroterephthalate; Hd, herbicide degradate; H, herbicide; I, insecticide; E, estimated; <, less than]

\begin{tabular}{|c|c|c|c|c|c|c|c|c|c|c|c|}
\hline \multirow{2}{*}{$\begin{array}{c}\text { Map } \\
\text { identifier } \\
\text { (fig. 1; } \\
\text { table 1) }\end{array}$} & \multirow[t]{2}{*}{$\begin{array}{c}\text { Short name } \\
\text { (fig. 1; table 1) }\end{array}$} & \multirow[t]{2}{*}{ Date } & \multirow{2}{*}{$\begin{array}{c}\text { DEA } \\
\text { (CIAT) } \\
(\mu \mathrm{g} / \mathrm{L}) \\
\text { Hd }\end{array}$} & \multirow{2}{*}{$\begin{array}{c}\begin{array}{c}\text { Acetochlor } \\
(\mu \mathrm{g} / \mathrm{L})\end{array} \\
\mathrm{H}\end{array}$} & \multirow{2}{*}{$\begin{array}{c}\begin{array}{c}\text { Atrazine } \\
(\mu \mathrm{g} / \mathrm{L})\end{array} \\
\mathrm{H}\end{array}$} & \multirow{2}{*}{$\begin{array}{c}\begin{array}{c}\text { Carbaryl } \\
\text { ( } \mu \mathrm{g} / \mathrm{L})\end{array} \\
\mathrm{I}\end{array}$} & \multirow{2}{*}{$\begin{array}{c}\text { Chlorpyrifos } \\
\text { ( } \mu \mathrm{g} / \mathrm{L})\end{array}$} & \multirow{2}{*}{$\begin{array}{c}\begin{array}{c}\text { DCPA } \\
\text { (dacthal) } \\
(\mu \mathrm{g} / \mathrm{L})\end{array} \\
H\end{array}$} & \multirow{2}{*}{$\begin{array}{c}\begin{array}{c}\text { Malaoxon } \\
\text { ( } \mu \mathrm{g} / \mathrm{L})\end{array} \\
\mathrm{I}\end{array}$} & \multirow{2}{*}{$\begin{array}{c}\begin{array}{c}\text { Metolachlor } \\
\text { ( } \mu \mathrm{g} / \mathrm{L})\end{array} \\
\mathrm{H}\end{array}$} & \multirow{2}{*}{$\begin{array}{c}\begin{array}{c}\text { Tebucon- } \\
\text { azole } \\
\text { ( } \mu \mathrm{g} / \mathrm{L})\end{array} \\
\mathrm{H}\end{array}$} \\
\hline & & & & & & & & & & & \\
\hline \multirow[t]{4}{*}{11} & Frio River ${ }^{1}$ & $5 / 12 / 2015$ & E0.008 & $<0.010$ & 0.015 & $<0.060$ & 0.0095 & $<0.0076$ & $<0.022$ & 0.007 & $<0.020$ \\
\hline & & $5 / 13 / 2015$ & $<0.010$ & $<0.010$ & 0.007 & $<0.060$ & 0.0115 & $<0.0076$ & $<0.022$ & 0.007 & $<0.020$ \\
\hline & & $10 / 22 / 2015$ & $<0.010$ & $<0.010$ & $<0.008$ & $<0.060$ & $<0.0100$ & 0.0095 & $<0.022$ & 0.006 & $<0.020$ \\
\hline & & $3 / 8 / 2016$ & $<0.011$ & 0.007 & 0.046 & $<0.060$ & $<0.0100$ & 0.0041 & $<0.022$ & 0.009 & 0.011 \\
\hline 13 & Urban rainfall 1 & $3 / 20 / 2015$ & $<0.010$ & $<0.010$ & $<0.008$ & $<0.060$ & $<0.0100$ & 0.0025 & $<0.022$ & $<0.012$ & $<0.020$ \\
\hline \multirow[t]{3}{*}{14} & Urban rainfall 2 & $5 / 13 / 2015$ & E0.006 & $<0.010$ & 0.017 & E0.011 & $<0.0100$ & $<0.0076$ & $<0.022$ & 0.009 & $<0.020$ \\
\hline & & $10 / 22 / 2015$ & $<0.010$ & $<0.010$ & $<0.008$ & $<0.060$ & $<0.0100$ & 0.0031 & $<0.022$ & $<0.012$ & $<0.020$ \\
\hline & & $3 / 9 / 2016$ & E0.013 & $<0.010$ & 0.051 & $<0.060$ & $<0.0100$ & 0.0032 & $<0.022$ & 0.046 & $<0.020$ \\
\hline \multirow[t]{3}{*}{15} & Urban rainfall 3 & $5 / 9 / 2014$ & E0.011 & $<0.010$ & 0.010 & E0.007 & $<0.0116$ & 0.0018 & 0.030 & $<0.012$ & $<0.020$ \\
\hline & & $5 / 12 / 2014$ & E0.007 & $<0.010$ & 0.011 & E0.004 & $<0.0100$ & 0.0015 & $<0.022$ & 0.004 & $<0.020$ \\
\hline & & $11 / 4 / 2014$ & $<0.010$ & $<0.010$ & $<0.008$ & $<0.060$ & $<0.0100$ & 0.0023 & $<0.022$ & $<0.012$ & $<0.020$ \\
\hline
\end{tabular}

${ }^{1}$ Rainfall samples collected at U.S. Geological Survey streamflow-gaging station 08195000 Frio River at Concan, Texas (Frio River site), were considered representative of rural rainfall. 


\section{Surface Water}

Sixteen pesticides $(7$ herbicides and 1 herbicide degradate; 5 insecticides and 3 insecticide degradates) each were detected in at least 1 surface-water sample ( 38 surfacewater samples were analyzed) (table 11). The herbicide metolachlor was detected most frequently (12 of 38 samples; 32 percent); concentrations of metolachlor were low (most were less than the LRL of $0.012 \mu \mathrm{g} / \mathrm{L}$ ) and similar to concentrations measured in rainfall, with the exception of 1 urban rainfall sample that had a substantially higher concentration (fig. 17). For the 6 pesticides detected in both surface-water and rainfall samples, the range of concentrations measured in the 2 sample types was similar (Opsahl and others, 2018), and for 5 of the 6 pesticides (excepting carbaryl), the maximum concentration measured in rainfall exceeded that measured in surface water (fig. 18). However, 10 pesticides detected in surface water were not detected in rainfall (table 11). In surface water and groundwater, a lower DAR indicates atrazine that was more recently applied; a DAR greater than 1 indicates greater prevalence of the degradate than the parent compound, attributed to microbial breakdown of the parent compound in soil (Thurman and Fallon, 1996), and reflects little recent inputs of fresh (undegraded) atrazine. The DAR was $0.30-0.85$ (median 0.75) for the 7 surface-water samples in which both DEA and atrazine were detected and were similar to the range in rainfall (0.25-1.10) (Opsahl and others, 2018), indicating that some of the surfacewater samples had a predominance of freshly applied atrazine but that other surface-water samples had a higher proportion of the degradate.

\section{Groundwater}

Nine pesticides were detected in at least 1 of the 115 groundwater samples collected (table 11). Among the unconfined wells, pesticides occurred much less frequently at the rural Seco well than at the 2 urban wells (Parkwood and Zarzamora wells). Three pesticides (atrazine, DEA, and simazine), all herbicides, each were detected in at least 1 of 29 samples collected from the rural Seco well. Of these, DEA was detected in 55 percent of the samples (16 of 29); the other 2 pesticides were detected in just 1 (atrazine) or 2 (simazine) samples. All concentrations of DEA were estimated (less than the LRL of $0.010 \mu \mathrm{g} / \mathrm{L}$ ). Most detections of DEA occurred during the first part of the study, in the dry period when WLA was low; DEA was not detected in any sample collected after May 2015, which was about 2 weeks after WLA began to rise (fig. 19) and throughout the remainder of the wet period.

Nine pesticides each were detected in at least 1 of the 59 total samples collected from the 2 urban wells (27 samples of confined groundwater at the deep Zarzamora well and 32 samples of unconfined groundwater at the shallow
Parkwood well) (table 11). Despite the difference in depths and hydrogeological character of the 2 urban wells, pesticide detection frequencies were similar, with the exception of prometon, which was detected only in samples collected at the shallow Parkwood well. The herbicides atrazine, DEA, and simazine were detected in more than 90 percent of samples collected at both wells (table 11). The herbicide prometon was detected in 61 percent ( 8 of 13) of the samples collected at Parkwood well during the dry period, but in only 7 percent (1 of 14) of the samples collected after May 2015 during the wet period (fig. 20A). In contrast to Parkwood well, the detection frequencies and concentrations at Zarzamora well changed little during contrasting dry and wet hydrologic conditions (fig. 20B). The herbicide metolachlor and the insecticides naphthol, azinphos-methyl, dieldrin, and fipronil sulfone (a degradate of fipronil) each were detected in just 1 urban groundwater sample (table 11).

Pesticide detection frequency at Comal 1 spring was intermediate between that at the rural well and that at the two urban wells. Four herbicides or herbicide degradatesatrazine, DEA, prometon, and simazine - were detected in at least 60 percent of the 27 samples collected at Comal 1 spring (table 11), and DEA was detected in all but 1 sample (96 percent). No other pesticides were detected in the samples collected at Comal 1 spring. There were no temporal patterns in concentrations of atrazine, DEA, or simazine evident from the samples collected at Comal 1 spring (fig. 21). Concentrations of prometon, however, generally increased with the increase in spring discharge, which began in August 2014, as hydrologic conditions transitioned between the dry and wet periods, but then decreased after July 2016, despite a continued increase in discharge.

The DAR was $0.10-3.0($ median $=1.86)$ for the 115 groundwater samples in which both atrazine and DEA were detected (Opsahl and others, 2018). Two samples collected from Parkwood well yielded DARs that were substantially less than 1 ( 0.10 and 0.27$)$, coinciding with relatively elevated concentrations of atrazine ( 0.26 and $0.071 \mu \mathrm{g} / \mathrm{L}$, respectively) (fig. 22A; Opsahl and others, 2018). These two samples were collected from Parkwood well in April 2016 during a period of rapid groundwater recharge, and the elevated atrazine concentrations measured in these samples were consistent with an influx of recently applied atrazine in recharge.

\section{Factors Affecting Pesticides}

The presence of trace concentrations of pesticides in rainfall in this study is consistent with concentrations of pesticides in rainfall in both developed and pristine areas of the United States (Thurman and Cromwell, 2000; Potter and Coffin, 2017). Postapplication losses of pesticides are reported to range from 0.2 to more than 90 percent and are related to many factors, including physical properties of the pesticide and climatic conditions (Van Pul and others, 1999; Barbash, 2007). For example, volatilization can be a major dissipation 
Table 11. Summary of pesticide detections in rainfall, surface-water, and groundwater samples collected from sites in the San Antonio segment of the Edwards aquifer, southcentral Texas, 2012-16.

[Estimated pesticide values reported at less than the laboratory reporting level were considered detections. NA, not applicable, Id, insecticide degradate; DEA, deethylatrazine; CIAT, 2-Chloro-4isopropylamino-6-amino-s-triazine; DCPA (dacthal), dimethyl tetrachloroterephthalate; Hd, herbicide degradate; H, herbicide; I, insecticide; Id, insecticide degradate]

\begin{tabular}{|c|c|c|c|c|c|c|c|c|c|c|c|c|}
\hline & \multirow{2}{*}{$\begin{array}{c}\text { Type of } \\
\text { pesti- } \\
\text { cide }\end{array}$} & \multicolumn{2}{|c|}{$\begin{array}{l}\text { Rainfall sites } \\
\text { (fig 1; table 1) }\end{array}$} & \multicolumn{4}{|c|}{$\begin{array}{l}\text { Surface-water sites } \\
\text { (fig. 1; table 1) }\end{array}$} & \multicolumn{4}{|c|}{$\begin{array}{l}\text { Groundwater sites } \\
\text { (fig. 1; table 1) }\end{array}$} & \multirow{2}{*}{$\begin{array}{l}\text { Detection } \\
\text { frequency } \\
\text { (percent) }^{4}\end{array}$} \\
\hline & & $\begin{array}{c}\text { Rural } \\
\text { rainfall' }\end{array}$ & $\begin{array}{l}\text { Urban } \\
\text { rainfall }\end{array}$ & $\begin{array}{l}\text { Frio } \\
\text { River }\end{array}$ & $\begin{array}{l}\text { Seco } \\
\text { Creek }\end{array}$ & $\begin{array}{l}\text { Culebra } \\
\text { Creek }\end{array}$ & $\begin{array}{l}\text { Helotes } \\
\text { Creek }\end{array}$ & $\begin{array}{l}\text { Seco } \\
\text { well }\end{array}$ & $\begin{array}{l}\text { Parkwood } \\
\text { well }^{2}\end{array}$ & $\begin{array}{l}\text { Zarzamora } \\
\text { well² }\end{array}$ & $\begin{array}{l}\text { Comal } 1 \\
\text { spring }^{3}\end{array}$ & \\
\hline Number of samples (n) & NA & 4 & 7 & 27 & 2 & 2 & 7 & 29 & 32 & 27 & 27 & NA \\
\hline Pesticide compound & \multicolumn{12}{|c|}{ Number of detections } \\
\hline 1-Naphthol & Id & 0 & 0 & 0 & 0 & 0 & 0 & 0 & 0 & 1 & 0 & 0.6 \\
\hline DEA (CIAT) & $\mathrm{Hd}$ & 1 & 4 & 4 & 1 & 0 & 3 & 16 & 32 & 26 & 26 & 68.9 \\
\hline Acetochlor & $\mathrm{H}$ & 1 & 0 & 0 & 0 & 0 & 0 & 0 & 0 & 0 & 0 & 0.6 \\
\hline Atrazine & $\mathrm{H}$ & 3 & 4 & 4 & 1 & 0 & 5 & 1 & 32 & 26 & 17 & 56.7 \\
\hline Azinphos-methyl & I & 0 & 0 & 0 & 0 & 0 & 0 & 0 & 0 & 1 & 0 & 0.6 \\
\hline Carbaryl & I & 0 & 3 & 2 & 0 & 0 & 3 & 0 & 0 & 0 & 0 & 4.9 \\
\hline Chlorpyrifos & I & 2 & 0 & 1 & 0 & 0 & 0 & 0 & 0 & 0 & 0 & 1.8 \\
\hline Cypermethrin & I & 0 & 0 & 1 & 0 & 0 & 0 & 0 & 0 & 0 & 0 & 0.6 \\
\hline DCPA (dacthal) & $\mathrm{H}$ & 2 & 6 & 2 & 0 & 2 & 4 & 0 & 0 & 0 & 0 & 9.8 \\
\hline Desulfinylfipronil amide & Id & 0 & 0 & 1 & 0 & 0 & 0 & 0 & 0 & 0 & 0 & 0.6 \\
\hline Desulfinylfipronil & Id & 0 & 0 & 2 & 0 & 0 & 1 & 0 & 0 & 0 & 0 & 1.8 \\
\hline Dieldrin & I & 0 & 0 & 0 & 0 & 0 & 0 & 0 & 1 & 0 & 0 & 0.6 \\
\hline Fipronil sulfide & Id & 0 & 0 & 1 & 0 & 0 & 0 & 0 & 0 & 0 & 0 & 0.6 \\
\hline Fipronil sulfone & Id & 0 & 0 & 0 & 0 & 0 & 0 & 0 & 1 & 0 & 0 & 0.6 \\
\hline Fipronil & I & 0 & 0 & 2 & 0 & 0 & 0 & 0 & 0 & 0 & 0 & 1.2 \\
\hline Fonofos & I & 0 & 0 & 1 & 0 & 0 & 0 & 0 & 0 & 0 & 0 & 0.6 \\
\hline Malaoxon & I & 0 & 1 & 0 & 0 & 0 & 0 & 0 & 0 & 0 & 0 & 0.6 \\
\hline Metolachlor & $\mathrm{H}$ & 4 & 3 & 8 & 2 & 1 & 1 & 0 & 1 & 0 & 0 & 12.2 \\
\hline Prometon & $\mathrm{H}$ & 0 & 0 & 3 & 0 & 0 & 2 & 0 & 9 & 0 & 17 & 18.9 \\
\hline Prometryn & $\mathrm{H}$ & 0 & 0 & 1 & 0 & 0 & 0 & 0 & 0 & 0 & 0 & 0.6 \\
\hline Simazine & $\mathrm{H}$ & 0 & 0 & 0 & 0 & 0 & 1 & 2 & 32 & 25 & 21 & 49.4 \\
\hline Tebuconazole & $\mathrm{H}$ & 1 & 0 & 0 & 0 & 0 & 0 & 0 & 0 & 0 & 0 & 0.6 \\
\hline Trifluralin & $\mathrm{H}$ & 0 & 0 & 1 & 0 & 0 & 0 & 0 & 0 & 0 & 0 & 0.6 \\
\hline Total number of detections per site & NA & 14 & 21 & 34 & 4 & 3 & 20 & 19 & 108 & 79 & 81 & NA \\
\hline Average number of detections per sample ${ }^{5}$ & NA & 3.5 & 3.0 & 1.7 & 2.0 & 1.5 & 2.9 & 0.7 & 3.4 & 2.9 & 3.0 & NA \\
\hline
\end{tabular}

${ }^{1}$ Rainfall samples collected at U.S. Geological Survey streamflow-gaging station 08195000 Frio River at Concan, Texas (Frio River site), were considered representative of rural rainfall.

${ }^{2}$ Well represents unconfined aquifer conditions.

${ }^{3}$ Samples from the Comal 1 spring site at Comal Springs, a spring at the downgradient end of the regional flow path (fig. 1), were for the purpose of this report considered groundwater samples representative of deeper, confined groundwater.

${ }^{4}$ Calculated for each compound as the total number of detections divided by the total number of samples $(n=164)$.

${ }^{5}$ Calculated for each site as the total number of detections of all pesticides divided by the number of samples. 


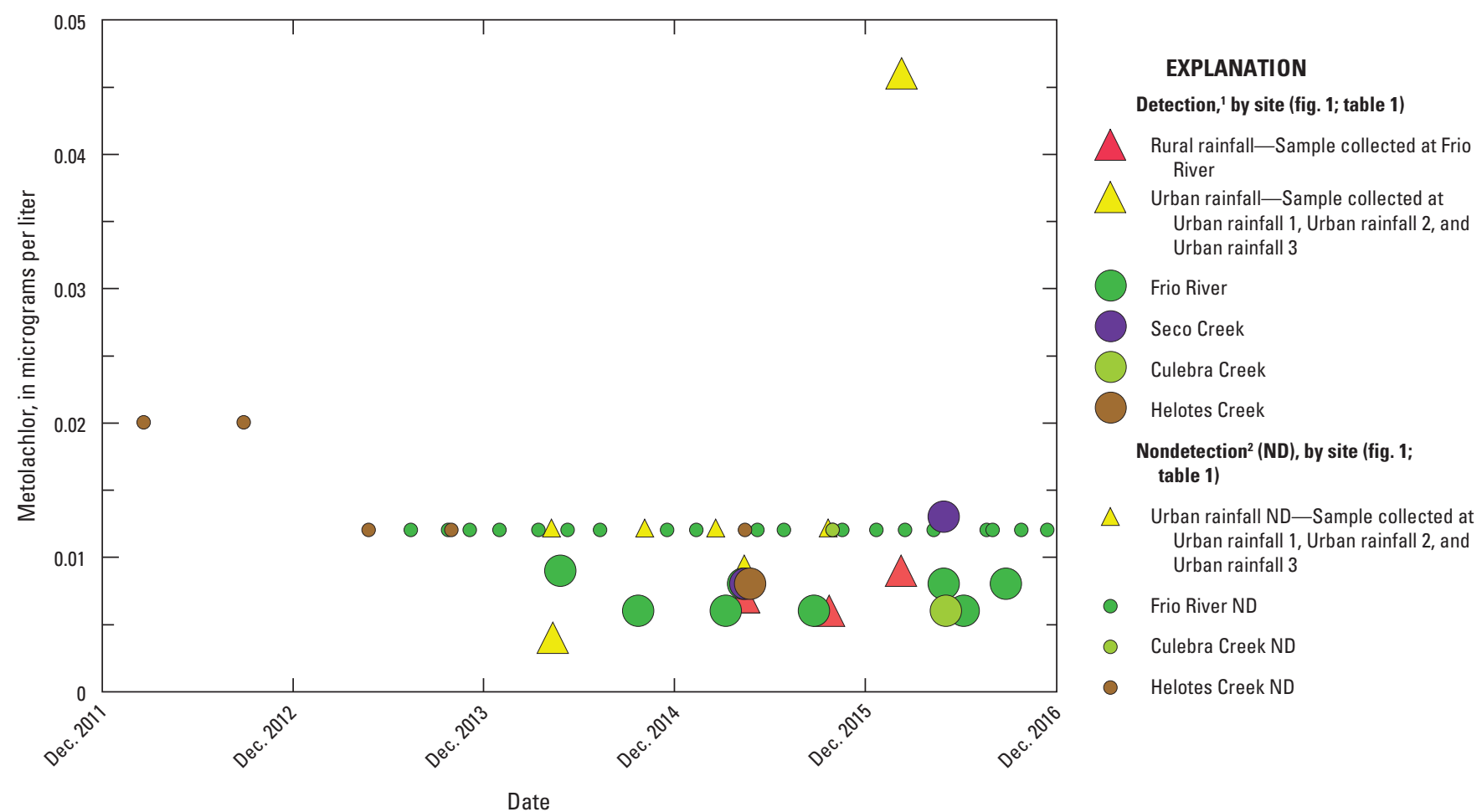

'Detections consist of values greater than or equal to the laboratory reporting level (LRL) and estimated values. A constituent concentration is considered estimated by the laboratory when results are greater than the long-term method detection level (LT-MDL) and less than the LRL; that is, a detection is considered likely, but quantification is considered questionable. The remark code of "E" (estimated) is assigned by the laboratory for these values (Childress and others, 1999).

${ }^{2}$ Nondetections are values reported for constituents that were analyzed for and were present at concentrations below the LRL and not quantified or were not present at all. For display purposes only, nondetections are depicted on this graph at the concentration that defines the LRL.

Figure 17. Concentrations of the herbicide metolachlor measured in surface-water and rainfall samples collected from sites in the San Antonio segment of the Edwards aquifer, south-central Texas, 2012-16.

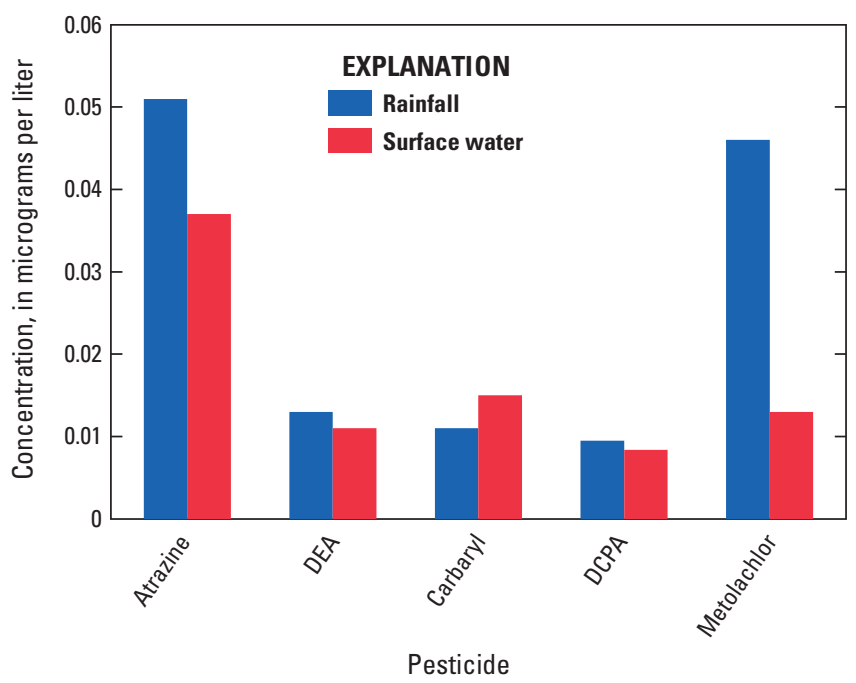

DEA, deethylatrazine; DCPA (dacthal), dimethyl tetrachloroterephthalate

Figure 18. Comparison of the maximum concentrations of the five pesticides that were measured in both rainfall and surface-water samples collected from sites in the San Antonio segment of the Edwards aquifer, south-central Texas, 2012-16. 


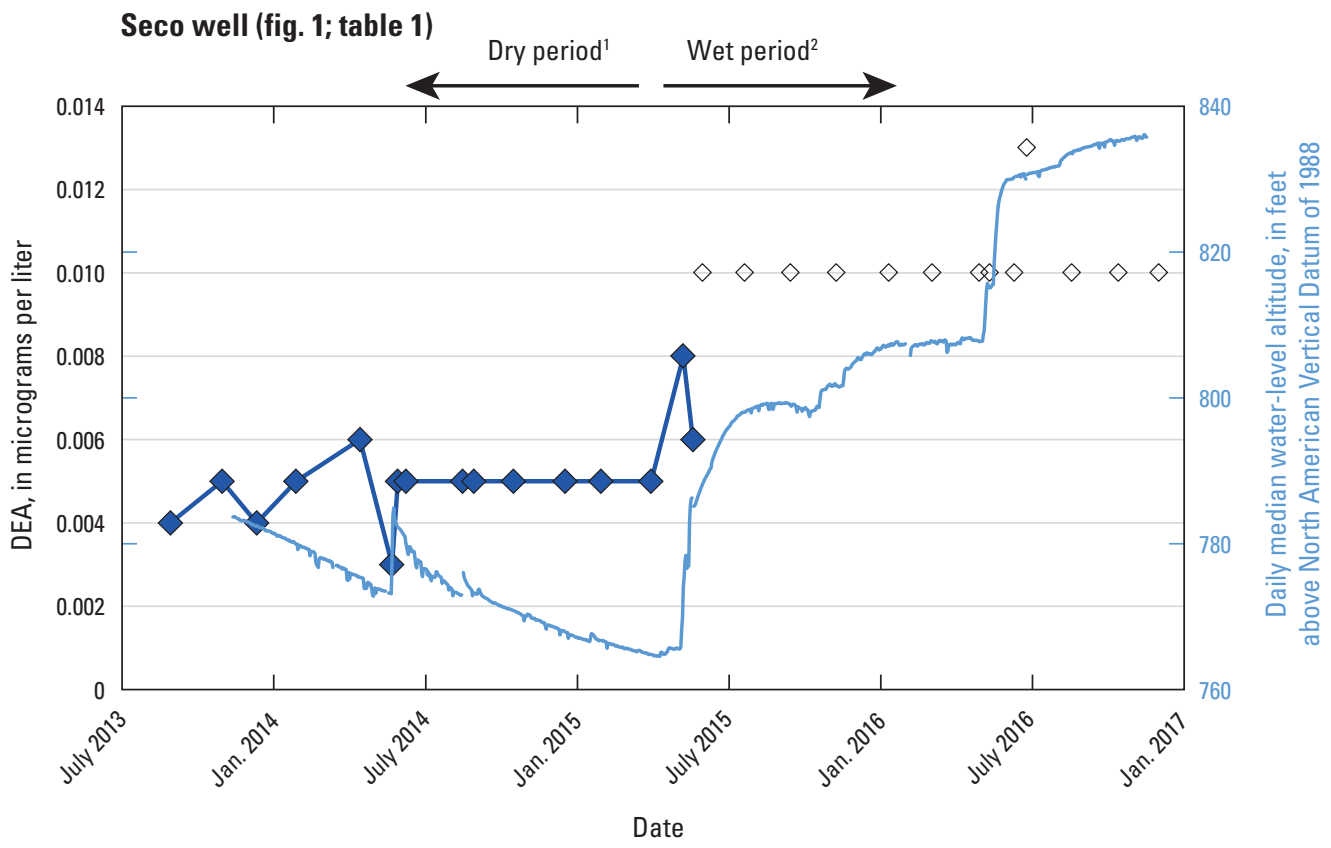

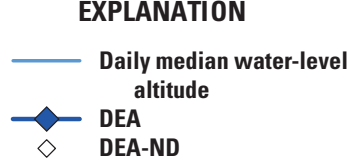

DEA, deethylatrazine; ND, nondetection

Detections consist of values greater than or equal to the laboratory reporting level (LRL) and estimated values. A constituent concentration is considered estimated by the laboratory when results are greater than the long-term method detection level (LT-MDL) and less than the LRL; that is, a detection is considered likely, but quantification is considered questionable. The remark code of "E" (estimated) is assigned by the laboratory for these values (Childress and others, 1999).

Nondetections are values reported for constituents that were analyzed for and were present at concentrations below the LRL and not quantified or were not present at all. For display purposes only, nondetections are depicted on this graph at the concentration that defines the LRL.

'July 2013 through May 2015 is referred to as the "dry period."

2June 2015 through December 2016 is referred to as the "wet period."

Figure 19. Daily median water-level altitude and concentrations of the atrazine degradate deethylatrazine (DEA) measured in water samples from Seco well in the San Antonio segment of the Edwards aquifer, south-central Texas, 2013-16.

route for DCPA, particularly under warm conditions with high soil moisture levels (U.S. Environmental Protection Agency, 1998). The volatility of DCPA likely accounts for its frequent occurrence and low concentrations $(0.0015-0.0032 \mu \mathrm{g} / \mathrm{L})$ in rainfall during this study (Opsahl and others, 2018). Rainfall composition can be highly variable among and within storms, and it is likely that rainfall samples collected during this study do not reflect the full variability of rainfall compositions.

The presence of a pesticide in rainfall is not necessarily an indication of pesticide origin - pesticides released into the atmosphere can be transported distances of a few meters to as many as thousands of kilometers (Van Pul and others, 1999). Three pesticides (atrazine DCPA, and metolachlor) and the pesticide degradate DEA were detected in both rural and urban rainfall at similar concentrations; the sources might be local or might be hundreds of kilometers distant. The insecticide carbaryl was detected in three of seven samples of urban rainfall but no samples of rural rainfall; conversely, the insecticide chlorpyrifos was detected in two of four samples of rural rainfall but no samples of urban rainfall. The disparate settings might indicate localized sources of these pesticides to rainfall, although these pesticides were frequently detected in rainfall samples collected in locations across the United States (Vogel and others, 2008).
Rainfall should be considered a source of many of the pesticides frequently detected in surface water. Among the pesticides most commonly detected in surface water (atrazine, DEA, carbaryl, DCPA, metolachlor, and prometon), all but prometon also were detected in at least one sample of rainfall (table 11). The maximum concentration measured in rainfall was higher than that measured in surface water for four of the five pesticides detected in both types of samples (fig. 18). In contrast, prometon and nine pesticides detected infrequently in surface water were not detected in rainfall, indicating that either they might have a local source in the watershed or the full range of pesticide occurrences in rainfall is not represented in the dataset.

The assemblage of pesticides detected in samples of surface water collected from the three rural streams (Frio River, Seco Creek, and Culebra Creek) differed from the assemblage detected in samples collected from the more urban Helotes Creek (table 11). However, this land-cover comparison is limited because only seven urban surface-water samples were collected, and they were collected from only one stream (Helotes Creek). The herbicide metolachlor was the pesticide most frequently detected in samples of rural surface water (11 of 31 samples; 35 percent), but was detected in only 1 sample of urban surface water (14 percent of samples). 


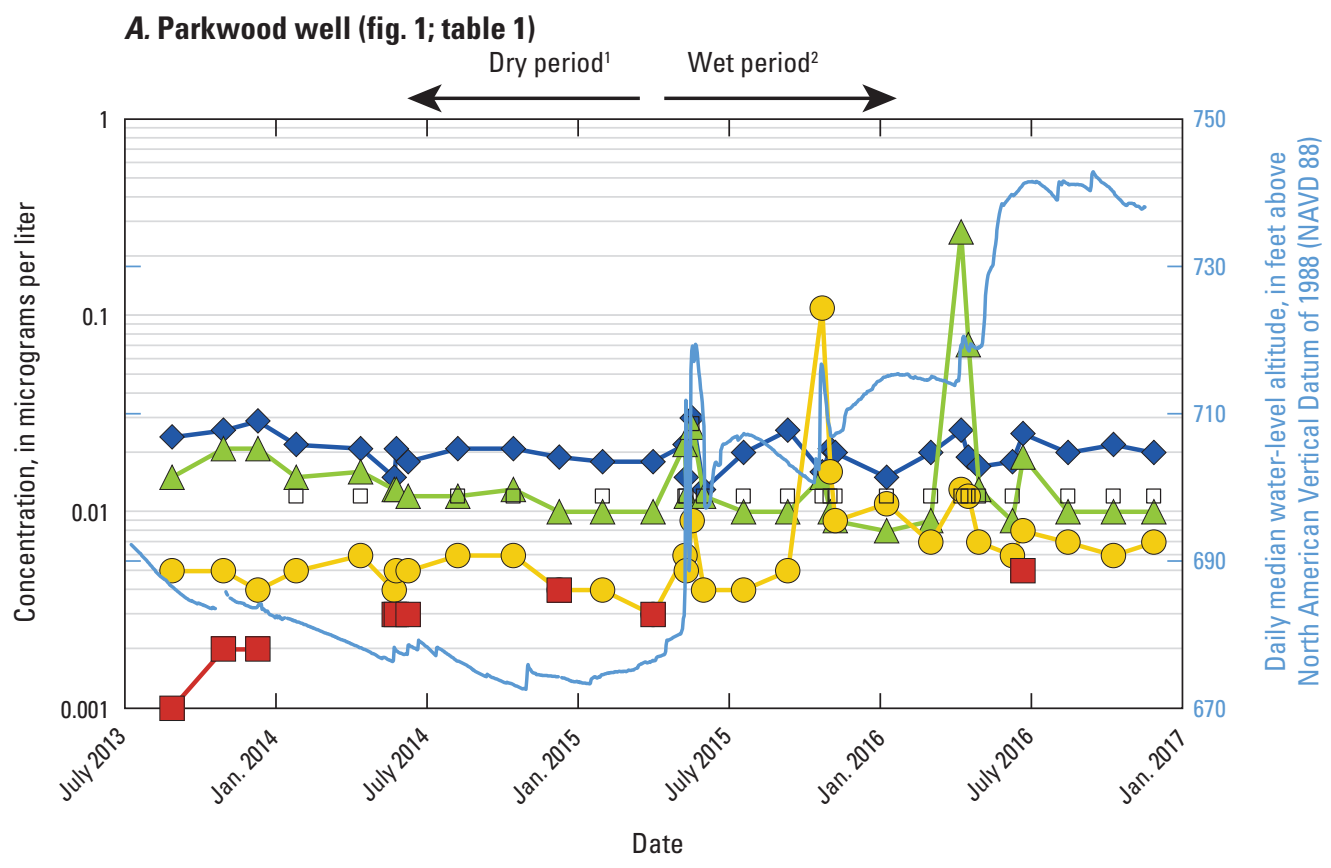

\section{EXPLANATION}

Daily median water-level altitude

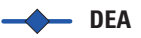

$\triangle$ Atrazine

- Simazine

- - Prometon

$\square \quad$ Prometon ND

DEA, deethylatrazine; ND, nondetection

\section{B. Zarzamora well (fig. 1; table 1)}

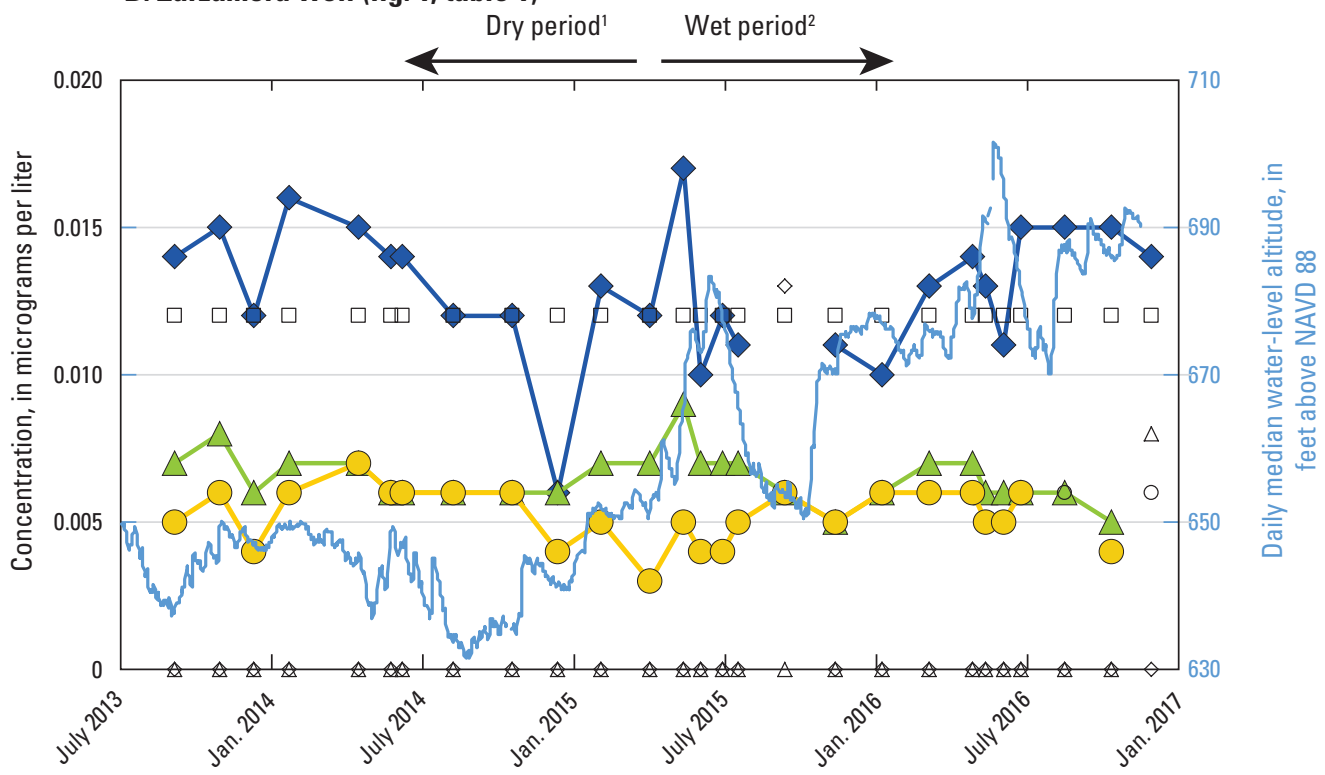

\section{EXPLANATION}

Daily median water-level altitude

$\checkmark$ DEA

$\triangle$ Atrazine

- - Simazine

$\diamond \quad$ DEA ND

$\triangle \quad$ Atrazine ND

○ Simazine ND

․ Prometon ND

DEA, deethylatrazine; ND, nondetection

Detections consist of values greater than or equal to the laboratory reporting level (LRL) and estimated values. A constituent concentration is considered estimated by the laboratory when results are greater than the long-term method detection level (LT-MDL) and less than the LRL; that is, a detection is considered likely, but quantification is considered questionable. The remark code of " $E$ " (estimated) is assigned by the laboratory for these values (Childress and others, 1999).

Nondetections are values reported for constituents that were analyzed for and were present at concentrations below the LRL and not quantified or were not present at all. For display purposes only, nondetections are depicted on this graph at the concentration that defines the LRL.

"July 2013 through May 2015 is referred to as the "dry period."

2June 2015 through December 2016 is referred to as the "wet period."

Figure 20. Daily median water-level altitude and concentrations of deethylatrazine (DEA), atrazine, and simazine measured in water samples from urban wells including $A$, Parkwood well and $B$, Zarzamora well in the San Antonio segment of the Edwards aquifer, southcentral Texas, 2013-16. 
Comal 1 spring (fig. 1; table 1)

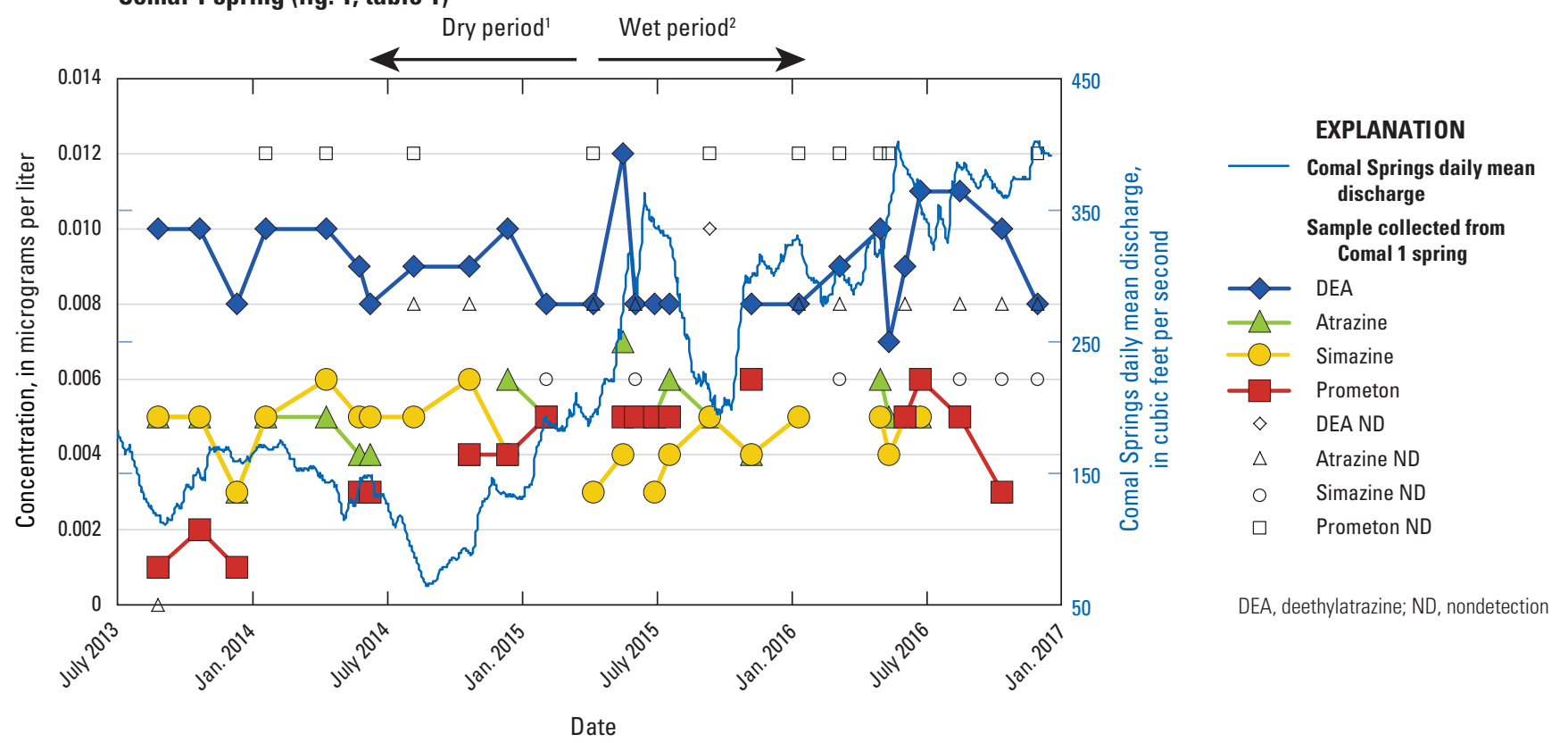

Detections consist of values greater than or equal to the laboratory reporting level (LRL) and estimated values. A constituent concentration is considered estimated by the laboratory when results are greater than the long-term method detection level (LT-MDL) and less than the LRL; that is, a detection is considered likely, but quantification is considered questionable. The remark code of " $E$ " (estimated) is assigned by the laboratory for these values (Childress and others, 1999).

Nondetections are values reported for constituents that were analyzed for and were present at concentrations below the LRL and not quantified or were not present at all. For display purposes only, nondetections are depicted on this graph at the concentration that defines the LRL.

"July 2013 through May 2015 is referred to as the "dry period."

2June 2015 through December 2016 is referred to as the "wet period."

Figure 21. Daily mean discharge at Comal Springs and concentrations of deethylatrazine (DEA), atrazine, simazine, and prometon measured in water samples collected from Comal 1 spring in the San Antonio segment of the Edwards aquifer, south-central Texas, 2013-16.

In contrast, the herbicide atrazine was the pesticide most frequently detected in samples of urban surface water ( 5 of 7 samples; 71 percent), but was detected less frequently in samples of rural surface water ( 5 of 31 samples; 16 percent). Eight insecticides ( 5 parent pesticides and 3 degradates) were detected in at least 1 sample of rural surface water, whereas only 1 insecticide (carbaryl) and 1 insecticide degradate (desulfinylfipronil) were detected in urban surface water. The larger number of insecticides detected in rural than urban settings is the reverse of the general pattern in the United States reported by Gilliom and others (2006), although the data analyzed in that study were collected between 1992 and 2001, and patterns might have changed over time.

Although surface water provides recharge to the aquifer, the assemblage of pesticides detected in groundwater was much less diverse than that in surface water (table 11). Pesticide detections in groundwater were dominated by atrazine, DEA, and simazine, which were among the five pesticides detected most frequently in a nationwide groundwater study during 1992-2001 (Gilliom and others,
2006). The frequent occurrence of these pesticides in groundwater reflects their mobility and persistence. For example, the more frequent occurrence of metolachlor than atrazine in rural surface water but the relative absence of metolachlor in groundwater likely results from the more rapid breakdown of metolachlor than atrazine based on observations of breakdown rates in soils (soil half-lives of 26 days for metolachlor and 146 days for atrazine) (Barbash and others, 1999). Dilution might also affect pesticide occurrence in Edwards aquifer groundwater; atrazine and DEA, when detected in surface water, occurred at higher concentrations (on the basis of their mean and maximum values) than did other pesticides (Opsahl and others, 2018). Their subsequent dilution within the aquifer therefore might still result in detectable concentrations.

Samples of urban surface water collected for this study are not fully representative of urban water in the San Antonio area. The comparison of urban surface water and groundwater is hampered by the small number of urban surface-water samples (seven) and the single urban surface-water site. 

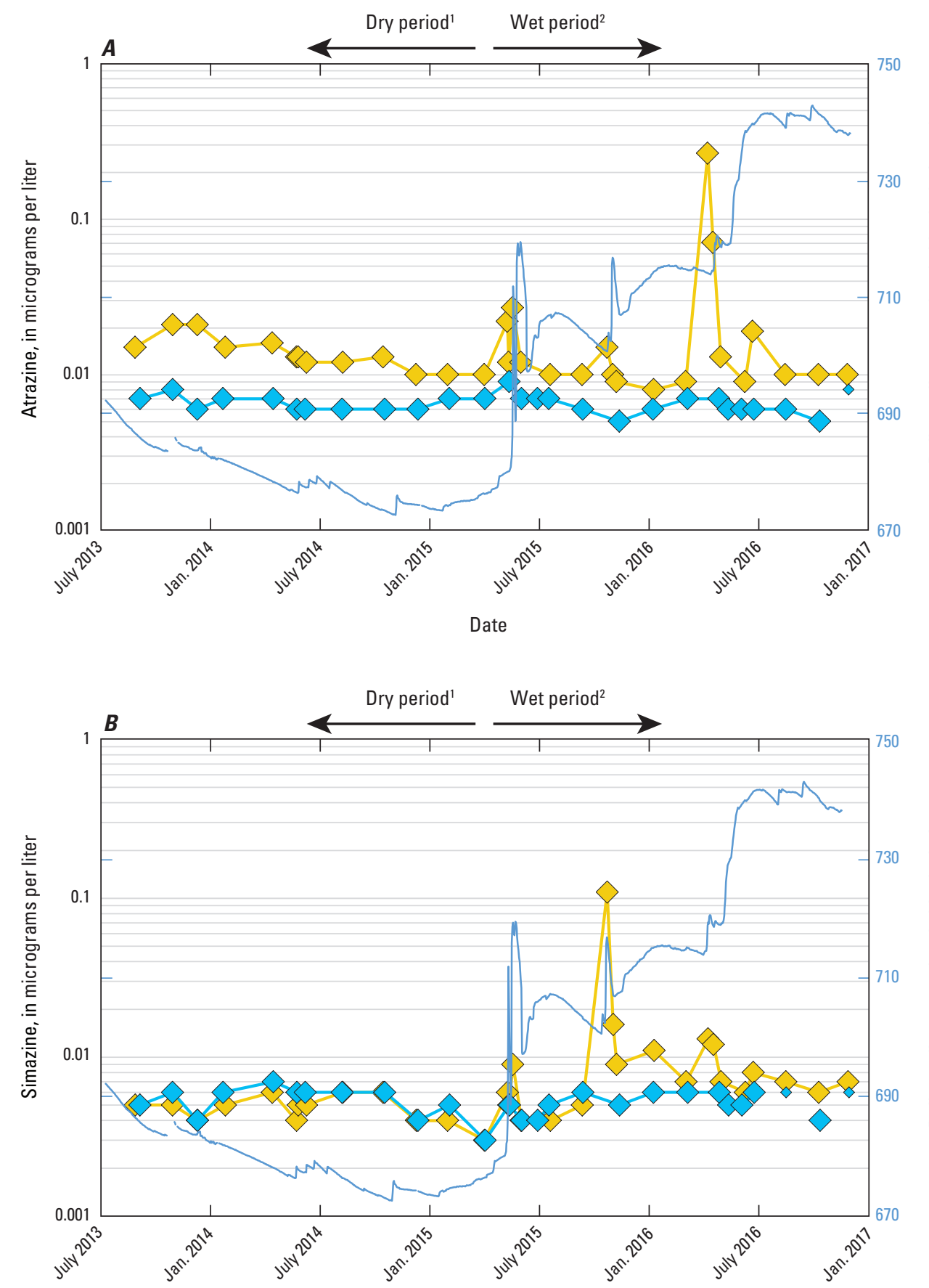

EXPLANATION

Daily median water-level altitude from Parkwood well Sample, by site (fig. 1; table 1)

Parkwood well

Zarzamora well

Zarzamora well ND

$\mathrm{ND}$, nondetection

Date

Detections consist of values greater than or equal to the laboratory reporting level (LRL) and estimated values. A constituent concentration is considered estimated by the laboratory when results are greater than the long-term method detection level (LT-MDL) and less than the LRL; that is, a detection is considered likely, but quantification is considered questionable. The remark code of " $E$ " (estimated) is assigned by the laboratory for these values (Childress and others, 1999).

Nondetections are values reported for constituents that were analyzed for and were present at concentrations below the LRL and not quantified or were not present at all. For display purposes only, nondetections are depicted on this graph at the concentration that defines the LRL.

'July 2013 through May 2015 is referred to as the "dry period."

2June 2015 through December 2016 is referred to as the "wet period."

Figure 22. Daily median water-level altitude at Parkwood well and pesticide concentrations measured in groundwater samples collected from urban wells (Parkwood and Zarzamora wells) for $A$, atrazine and $B$, simazine in the San Antonio segment of the Edwards aquifer, south-central Texas, 2013-16. 
This lack of representativeness is evidenced by detections of the herbicide simazine, which was detected in only one sample of surface water but was consistently detected in shallow urban groundwater. However, simazine was detected in 23 percent of 40 samples collected from 5 urban recharge streams sampled between 2001 and 2012 (Opsahl, 2012). Additionally, Opsahl (2012) reported detections of the pesticides benfluralin, DCPA, diazinon, disulfoton, malathion, and pendimethalin, all of which were not detected in samples collected in this study. Other urban streams, not sampled for this study, likely contribute a greater diversity of pesticides to the aquifer.

Land cover and aquifer hydrogeology influenced pesticide contamination of Edwards aquifer groundwater. Average number of pesticide detections for samples of groundwater from both the shallow, unconfined and deeper, confined urban wells (Parkwood and Zarzamora wells, respectively) were more contaminated by pesticides than were samples from the unconfined and rural Seco well (table 11). Atrazine, DEA, and simazine were detected consistently (more than 90 percent of samples) throughout the study in samples collected at the urban wells, and prometon was detected primarily during the dry period in the shallow, unconfined urban Parkwood well (fig. 20). At the rural Seco well, which is similar in depth to the deep, confined urban well (Zarzamora well), only DEA was detected, and only during the dry period when WLAs were low (fig. 19). In groundwater samples collected during 1996-2006, the most frequently detected pesticides (atrazine, DEA, and simazine) were detected in more than 50 percent of samples of shallow urban unconfined groundwater (Musgrove and others, 2010). Based on the high rate of detection of atrazine, DEA, and simazine in shallow urban unconfined groundwater, Musgrove and others (2010) concluded that "the urban environment is a source of anthropogenic contaminants to Edwards aquifer groundwater," a finding that is supported by the results of this study.

Hydrogeological characteristics affected concentrations and temporal patterns of pesticides detected in the urban wells. Concentrations of atrazine were higher and more variable in the shallow, unconfined well (Parkwood) than at the deeper, confined well (Zarzamora); concentrations of simazine in the two wells were similar during the dry period, when WLAs were low, but diverged during the wet period, after WLAs began to rise (fig. $22 A, B$ ). In the urban wells, the ubiquity and relatively constant, low concentrations of atrazine, DEA, simazine (fig. 20A, $B$ ), and -in the shallow Parkwood wellprometon during the dry period (fig. 20A) likely indicate legacy contamination present at trace concentrations in the diffuse flow of the aquifer. During the wet period, which was punctuated by at least three recharge events and rising WLAs, there was a dynamic response at the shallow Parkwood well (fig. 20A). Concentrations of atrazine and simazine peaked in May and early November 2015 and in mid-April 2016, coinciding with rapid decreases in SC (fig. $5 B$ ) that signaled an influx of recharging surface water. The highest simazine concentration occurred in November 2015, and the highest atrazine concentration occurred in April 2016; in each case, the concentration was about 20 times greater than the ambient concentration (figs. 20A, 22A, B). The higher concentrations measured during periods of groundwater recharge indicate that groundwater in the shallow Parkwood well is in close communication with surface water and therefore vulnerable to contamination. Although much more muted, there also was a slight response at the deep Zarzamora well: atrazine concentration increased slightly in May 2015, when the rise in the WLA first began as hydrologic conditions transitioned from dry to wet.

The geochemical time series at Comal 1 spring, which integrates flow from the entire aquifer segment, showed little response to the change in hydrologic conditions from the dry period to the wet period (fig. 21). Atrazine, DEA, simazine, and prometon were frequently detected, but at concentrations that were consistently low and similar to ambient concentrations in the urban wells; only prometon showed any systematic variability. The relatively unvarying concentrations indicate that the regional component of groundwater is buffered from brief spikes in contamination associated with recharge events, but also indicate that the presence of pesticides has become a ubiquitous feature of Edwards aquifer groundwater.

\section{Pesticide Inputs and Cycling in the Edwards Aquifer}

The varied inputs of pesticides in rainfall, surface water, and groundwater in the Edwards aquifer region are evidence of anthropogenic sources of aquifer contamination and therefore important to current and future water-quality concerns for the Edwards aquifer. Given the small number of rainfall samples collected for this study and the large amount of variability in pesticide assemblage among rainfall events, rainfall samples likely do not represent the full range of variability across the entire study area. Similarly, for urban surface water, all urban samples are from one stream-Helotes Creek-results from which likely do not fully characterize the variability of potential recharge from streams in the urban San Antonio area. Nevertheless, the results of this study lead to several conclusions. The urban environment is a source of pesticide contamination to Edwards aquifer groundwater; urban wells, both shallow and deep, had higher detections of pesticides than did the rural well (table 11). The response to recharge events at the shallow, urban Parkwood well (fig. 5B) indicates that, in addition to background concentrations in diffuse flow, some pesticides are entering the aquifer with recharge waterhigher concentrations were observed in response to specific recharge events. Conversely, dilution by recharge water could decrease concentrations of other pesticides in groundwater; the trace concentrations of several pesticides not present in stormwater runoff during the dry period may have been diluted to less than the detection level during the wet period, as seen for Seco well (fig. 19). Those pesticides with higher 
concentrations are still likely to be detected, even with dilution that occurs in the aquifer.

Natural processes, such as biological degradation and alteration of individual pesticides, potentially affect the fate and transport of pesticides throughout the aquifer (Gilliom and others, 2006). Degradation of some pesticides, such as the degradation of atrazine to DEA, requires oxic conditions (Scribner and others, 2005), which occur in the Edwards aquifer. The presence of DEA in rainfall and surface water and their low DAR ratios (median DAR of 0.53 and 0.75 for rainfall and surface water, respectively) in comparison to groundwater (median DAR of 1.86) (Opsahl and others, 2018) indicate that continued atrazine degradation occurs during the transition from surface water to groundwater. The routine detection of the parent compound atrazine in groundwater samples, including discharge at Comal 1 spring (fig. 21), however, indicates that groundwater residence times, traveltimes, and other factors do not allow for the complete degradation of atrazine within the aquifer.

\section{Factors Affecting Aquifer Vulnerability}

The Edwards aquifer, like many karst aquifers, is highly susceptible to contamination because of high porosity and permeability and rapid flow of recharging surface water through conduits. Measured concentrations of $\mathrm{NO}_{3}$ and pesticides - the compounds of focus for this study - are currently low relative to levels of regulation for drinking water (for example, $10 \mathrm{mg} / \mathrm{L}$ for $\mathrm{NO}_{3}$ and $3 \mu \mathrm{g} / \mathrm{L}$ for atrazine; U.S. Environmental Protection Agency, 2017b). Nonetheless, elevated $\mathrm{NO}_{3}$ concentrations relative to national background values (Dubrovsky and others, 2010) and the widespread detection of pesticides indicate that the Edwards aquifer is vulnerable to contamination and that vulnerability is affected by factors such as land cover, aquifer hydrogeology, and changes in hydrologic conditions.

\section{Land Cover}

Land cover has a strong influence on the vulnerability of Edwards aquifer groundwater to the occurrence of nutrients and pesticides. Greater vulnerability of groundwater in urban areas relative to rural areas was evident from results for urban groundwater sites, which generally had higher $\mathrm{NO}_{3}$ concentrations, elevated $\delta^{15} \mathrm{~N}-\mathrm{NO}_{3}$ values, a greater diversity of pesticide detections, and higher pesticide concentrations (fig. 22; tables 9, 11). The continuum of water quality from unconfined rural groundwater (least affected by anthropogenic contamination) to unconfined urban groundwater (most affected by anthropogenic contamination) sites (fig. 14) demonstrates enhanced vulnerability of urban versus rural land cover. The deeper, confined urban groundwater sites were generally more similar to the urban unconfined sites than to the rural unconfined site with respect to the occurrence and concentration of nutrients and pesticides. There were, however, spatial variations in the anthropogenic contributions to the shallow, urban unconfined wells; for example, Parkwood well had a greater degree of $\mathrm{NO}_{3}$ contamination than did Shavano well. Differences in contaminant occurrences and concentration among unconfined urban wells indicate that the urban parts of the aquifer are not uniformly vulnerable, but rather are affected by spatial differences in the sources of nutrients and pesticides.

\section{Aquifer Hydrogeology}

Comparison of groundwater samples collected from the shallow, unconfined and deeper, confined parts of the aquifer indicates that aquifer hydrogeology—specifically including aquifer confinement and recharge pathwaysaffects groundwater vulnerability. In urban areas, the shallow, unconfined groundwater sites showed greater temporal variability in both nutrient and pesticide concentrations, as well as a greater degree of contamination, than did deeper, confined groundwater sites. In comparison to that of the shallow, unconfined groundwater sites, the water quality of the deeper, confined groundwater sites was relatively invariant during this multiyear study. Tracers of water-rock interaction indicate that confined groundwater is well mixed and more geochemically evolved with longer residence times (fig. 7); however, most confined groundwater sites had elevated $\mathrm{NO}_{3}$ concentrations and exhibited pesticide detections, providing evidence for a component of local recharge. The presence of a component of local recharge is consistent with previous studies that have indicated that, while groundwater throughout the Edwards aquifer is generally young (with mixtures ranging from less than 1 to about 40 years in apparent age), deeper groundwater is older and less influenced by anthropogenic activities (Musgrove and others, 2011). In this study, the relation between the degree of confinement and influence from anthropogenic activities is demonstrated by samples from the urban, confined Mission well, which had the highest $\mathrm{Mg} / \mathrm{Ca}$ ratios, evidence of groundwater with longer residence time that has not - to date - been substantially affected by anthropogenic activities. Continued loading of compounds of concern in urban recharge, however, might ultimately affect deeper parts of the aquifer as legacy contamination accumulates in diffuse flow. Although aquifer hydrogeology is an important factor related to aquifer vulnerability, land cover likely has a greater influence on pesticide contamination of groundwater.

\section{Changes in Hydrologic Conditions}

Changes in hydrologic conditions affect water quality and the associated transport of nutrients and pesticides by providing conditions conducive for transport or dilution in the aquifer, particularly during periods of groundwater recharge. Temporal variability in hydrologic conditions for the Edwards 
aquifer is apparent in data for surface water as a source of groundwater recharge (figs. 6, 7), WLA in wells (fig. 5A-F), spring discharge (fig. 5G), and groundwater quality (figs. 7-9, 12-22). The observed temporal variability affects recharge sources, recharge amounts, groundwater traveltimes, flow routing, water-rock interaction processes, dilution, mixing, and, in turn, water quality. Observed variation in nutrient and pesticide concentrations at streams in response to changing flow conditions (figs. 10-11; Opsahl and others, 2018) indicates that recharge water quality is variable over time and may be different for each event. Additionally, the variability of water quality observed at shallow, unconfined wells (for example, Parkwood and Shavano wells) from the dry period to the wet period, when water quality becomes more variable, and at Parkwood well in response to recharge events, indicates that water quality is dynamic on multiple time scales. An understanding of the relation between variability in hydrologic conditions and water quality provides a foundation on which to assess long-term changes in water quality and to distinguish between short-term, hydrologically induced variation and longer term trends.

\section{Summary}

The San Antonio segment of the Edwards aquifer, located in south-central Texas, is a designated sole-source aquifer and the primary water supply for more than 1.7 million people in the City of San Antonio and surrounding area. The Edwards aquifer recharge zone is particularly susceptible to contamination from the land surface because of the dynamic and rapid recharge that occurs through karst features such as sinkholes and losing streams during groundwater recharge events. The U.S. Geological Survey, in cooperation with the San Antonio Water System, performed a study from 2010 to 2016 to better understand how water quality changes under a range of hydrologic conditions and in contrasting landcover settings (rural and urban) in the Edwards aquifer. The study design included continuous hydrologic monitoring, continuous water-quality monitoring, and discrete sample collection for a detailed characterization of water quality at a network of sites throughout the aquifer system. The sites were selected to encompass a "source-to-sink" (that is, from aquifer recharge to aquifer discharge) approach. Network sites were selected to characterize rainfall, recharging surface water, and groundwater; groundwater sites included wells in the unconfined part of the aquifer (unconfined wells) and in the confined part of the aquifer (confined wells) and a major discharging spring. Storm-related samples-including rainfall samples, stormwater-runoff (surface-water) samples, and groundwater samples-were collected to characterize the aquifer response to recharge.

Rainfall often contained measurable concentrations of nitrate, nitrite, dissolved organic nitrogen, and orthophosphate at both rural and urban rainfall sites, indicating that atmospheric deposition is a source of nitrogen and phosphorous to the study area. Nitrate was the dominant nitrogen species at most surface-water sites. The median nitrate concentrations at surface-water sites were similar to or higher than the estimated national background concentration for streams. The higher concentration at Helotes Creek might result from a contribution of nitrate from urban sources. Median nitrate concentrations for both rural and urban surface-water sites examined in this study were substantially lower than the national background concentration for streams in agricultural areas and are therefore consistent with minor inputs of fertilizer.

The total variability in nitrate at Seco well was relatively small. Although the difference in nitrate concentration between the dry period and the wet period was small, it is distinguishable outside of the nitrate sensor's precision, indicating that nitrate concentrations at this site responded to longer term changes in hydrologic conditions. In response to frequent rainfall during the transition to the wet period in spring 2015, water-level altitude at Parkwood well rose rapidly, by about 40 feet over a period of a few days, and concurrently, nitrate concentration decreased from about 2.7 milligrams per liter to less than 1 milligram per liter. Mixing between ambient groundwater and lower nitrate recharging stormwater runoff derived directly from recharge streams such as Helotes Creek can account for the rapid and short-term dilution of ambient water at Parkwood well.

The small range of delta nitrogen-15 of nitrate $\left(\delta^{15} \mathrm{~N}\right.$ nitrate $\left[\mathrm{NO}_{3}\right]$ ) values for Seco well and corresponding low $\mathrm{NO}_{3}$ concentrations indicate predominantly natural, soilderived $\mathrm{NO}_{3}$ with little contribution from anthropogenic sources. In contrast, Parkwood well (with the exception of samples collected in response to recharge events) had the highest $\delta^{15} \mathrm{~N}-\mathrm{NO}_{3}$ values and $\mathrm{NO}_{3}$ concentrations, which is consistent with mixing with a component of $\mathrm{NO}_{3}$ from human or animal waste sources. Other groundwater sites were intermediate in their $\delta^{15} \mathrm{~N}-\mathrm{NO}_{3}$ and concentration values, with higher $\delta^{15} \mathrm{~N}-\mathrm{NO}_{3}$ values corresponding to higher $\mathrm{NO}_{3}$ concentrations. $\mathrm{NO}_{3}$ concentrations at Parkwood well indicate that about two-thirds of the $\mathrm{NO}_{3}$ in groundwater samples collected for this study might result from anthropogenic $\mathrm{NO}_{3}$ sources, assuming that 1 milligram per liter is the natural background concentration and the remainder (2.12 milligrams per liter) is anthropogenic.

Natural biogeochemical processes in the aquifer affect the fate and transport of all nitrogen species and play a role in determining the distribution of $\mathrm{NO}_{3}$ concentrations throughout the aquifer. The process of nitrification of dissolved organic nitrogen and ammonia from rainwater and surface water might be an important but previously unaccounted for source of $\mathrm{NO}_{3}$ to Edwards aquifer groundwater, as evidenced by the decrease in dissolved organic nitrogen plus ammonia concentrations from rainfall to surface water to groundwater and the corresponding increase in $\mathrm{NO}_{3}$ concentration. Characterization of sources, fate, and transport of $\mathrm{NO}_{3}$ in the San Antonio segment of the Edwards aquifer therefore requires consideration of all nitrogen species. 
At least 1 pesticide was detected in each of the 11 rainfall samples analyzed. Sixteen pesticides were detected in at least 1 surface-water sample. Nine pesticides were detected in at least 1 of the 115 groundwater samples collected. Among the unconfined wells, pesticides occurred much less frequently at the rural Seco well than at the 2 urban wells (Parkwood and Zarzamora). Average number of pesticide detections for samples of groundwater from both the shallow, unconfined and deeper, confined urban wells (Parkwood and Zarzamora, respectively) were more contaminated by pesticides than were samples from the unconfined and rural Seco well.

The ubiquity and relatively constant, low concentrations of atrazine, deethylatrazine, simazine, and -in the shallow Parkwood well - prometon during the dry period likely indicate legacy contamination present at trace concentrations in the diffuse flow of the aquifer. The relatively unvarying concentrations indicate that the regional component of groundwater is buffered from brief spikes in contamination associated with recharge events, but also indicate that the presence of pesticides has become a ubiquitous feature of Edwards aquifer groundwater. The response to recharge events at the shallow urban Parkwood well indicates that, in addition to background concentrations in diffuse flow, some pesticides are entering the aquifer with recharge water-higher concentrations were observed in response to specific recharge events. The routine detection of the parent compound atrazine in groundwater samples, including discharge at Comal 1 spring, however, indicates that groundwater residence times, traveltimes, and other factors do not allow for the complete degradation of atrazine within the aquifer.

Elevated $\mathrm{NO}_{3}$ concentrations relative to national background values and the widespread detection of pesticides indicate that the Edwards aquifer is vulnerable to contamination and that vulnerability is affected by factors such as land cover, aquifer hydrogeology, and changes in hydrologic conditions. Greater vulnerability of groundwater in urban areas relative to rural areas was evident from results for urban groundwater sites, which generally had higher $\mathrm{NO}_{3}$ concentrations, elevated $\delta^{15} \mathrm{~N}-\mathrm{NO}_{3}$ values, a greater diversity of pesticides, and higher pesticide concentrations. Differences in contaminant occurrences and concentration among unconfined urban wells indicate that the urban parts of the aquifer are not uniformly vulnerable, but rather are affected by spatial differences in the sources of nutrients and pesticides. In urban areas, the shallow, unconfined groundwater sites showed greater temporal variability in both nutrient and pesticide concentrations, as well as a greater degree of contamination, than did deeper, confined groundwater sites. In comparison to that of the shallow, unconfined groundwater sites, the water quality of the deeper, confined groundwater sites was relatively invariant during this multiyear study. Continued loading of compounds of concern in urban recharge, however, might ultimately affect deeper parts of the aquifer as legacy contamination accumulates in diffuse flow. Although aquifer hydrogeology is an important factor related to aquifer vulnerability, land cover likely has a greater influence on pesticide contamination of groundwater. Temporal variability in hydrologic conditions for the Edwards aquifer is apparent in data for surface water as a source of groundwater recharge, water-level altitude in wells, spring discharge, and groundwater quality. Observed variation in nutrient and pesticide concentrations at streams (for example, the Frio River and Helotes Creek) in response to changing flow conditions indicates that recharge water quality is variable over time and may be different for each event. Additionally, the variability of water quality observed at shallow, unconfined wells (for example, Parkwood and Shavano) from the dry period to the wet period, when water quality becomes more variable, and at Parkwood well in response to recharge events indicates that water quality is dynamic on multiple timescales. An understanding of the relation between variability in hydrologic conditions and water quality provides a foundation on which to assess longterm changes in water quality and to distinguish between short-term, hydrologically induced variation and longer term trends.

\section{References Cited}

Adams, C.D., and Thurman, E.M., 1991, Formation and transport of deethylatrazine in the soil and vadose zone: Journal of Environmental Quality, v. 20, p. 540-547.

American Water Works Association, 1998, Standard methods for the examination of water and wastewater (20th ed.): Washington, D.C., American Public Health Association, American Water Works Association, and Water Environment Federation, pt. 3120, p. 3-37 to 3-43.

Ansari, A.A., Gill, S.S., Lanza, G.R., and Rast, W., 2010, Eutrophication-Causes, consequences and control: New York, Springer Science and Business Media, 394 p.

Barbash, J.E., 2007, The geochemistry of pesticides, in Holland, H.D., and Turekian, K.K., eds., Treatise on geochemistry: Oxford, United Kingdom, Elsevier-Pergamon Press, p. 1-43.

Barbash, J.E., Thelin, G.P., Kolpin, D.W., and Gilliom, R.J., 1999, Distribution of major herbicides in ground water of the United States: U.S. Geological Survey Scientific Investigations Report, 98-4245, $64 \mathrm{p}$.

Barker, R.A., and Ardis, A.F., 1996, Hydrogeologic framework of the Edwards-Trinity aquifer system, west-central Texas: U.S. Geological Survey Professional Paper 1421-B, 61 p. 
Böhlke, J.K., Mroczkowski, S.J., and Coplen, T.B., 2003, Oxygen isotopes in nitrate- - New reference materials for ${ }^{18} \mathrm{O}:{ }^{17} \mathrm{O}:{ }^{16} \mathrm{O}$ measurements and observations on nitratewater equilibration: Rapid Communications in Mass Spectrometry, v. 17, no. 16, p. 1835-1846. [Also available at http://onlinelibrary.wiley.com/doi/10.1002/rcm.1123/full.]

Bullen, T.D., Krabbenhoft, D., and Kendall, C., 1996, Kinetic and mineralogic controls on the evolution of groundwater chemistry and ${ }^{87} \mathrm{Sr} r{ }^{86} \mathrm{Sr}$ in a sandy silicate aquifer, northern Wisconsin: Geochimica et Cosmochimica Acta, v. 60, no. 10 , p. 1807-1821.

Burkham, D.C., 1985, An approach for appraising the accuracy of suspended-sediment data: U.S. Geological Survey Professional Paper 1333, 18 p., accessed February 13, 2018, at https://pubs.usgs.gov/pp/1333/report.pdf.

Bush, P.W., Ardis, A.F., Fahlquist, Lynne, Ging, P.B., Hornig, C.E., and Lanning-Rush, Jennifer, 2000, Water quality in south-central Texas, 1996-98: U.S. Geological Survey Circular 1212, 32 p.

Campbell, J.L., Hornbeck, J.W., McDowell, W.H., Buso, D.C., Shanley, J.B., and Likens, G.E., 2000, Dissolved organic nitrogen budgets for upland forested ecosystems in New England: Biogeochemistry, v. 49, p. 123-142.

Childress, C.J.O., Foreman, W.T., Connor, B.F., and Maloney, T.J., 1999, New reporting procedures based on long-term method detection levels and some considerations for interpretations of water-quality data provided by the U.S. Geological Survey National Water Quality Laboratory: U.S. Geological Survey Open-File Report 99-193, 19 p.

Choi, W.-J., Han, G.-H., Lee, S.-M., Lee, G.-T., Yoon, K.-S., Choi, S.-M., and Ro, H.-M., 2007, Impact of land-use types on nitrate concentration and $\delta{ }^{15} \mathrm{~N}$ in unconfined groundwater in rural areas of Korea: Agriculture, Ecosystems and Environment, v. 120, p. 259-268.

Clark, I.D., and Fritz, P., 1997, Environmental isotopes in hydrogeology: Boca Raton, Fla., Lewis Publishers, 328 p.

Clark, A.K., and Journey, C.E., 2006, Flow paths in the Edwards aquifer, northern Medina and northeastern Uvalde Counties, Texas, based on hydrologic identification and geochemical characterization and simulation: U.S. Geological Survey Scientific Investigations Report 20065200,48 p.

Cooper, R., Thoss, V., and Watson, H., 2007, Factors influencing the release of dissolved organic carbon and dissolved forms of nitrogen from a small upland headwater during autumn runoff events: Hydrological Processes, v. 21, p. 622-633.
Coplen, T.B., Qi, Haiping, Révész, Kinga, Casciotti, Karen, and Hannon, J.E., 2012, Determination of the $\delta^{15} \mathrm{~N}$ and $\delta^{18} \mathrm{O}$ of nitrate in water; RSIL lab code 2900, chap. 17 of Stable isotope-ratio methods, sec. C of Révész, Kinga, and Coplen, T.B., eds., Methods of the Reston Stable Isotope Laboratory: U.S. Geological Survey Techniques and Methods, book 10, 35 p., accessed April 28, 2017, at https:// pubs.usgs.gov/tm/2006/tm10c17/.

Craig, H., 1961, Isotopic variations in meteoric waters: Science, v. 133, p. 1702-1703.

Cunningham, W.L., and Schalk, C.W., comps., 2011, Groundwater technical procedures of the U.S. Geological Survey: U.S. Geological Survey Techniques and Methods 1-A1, 151 p., accessed April 1, 2017, at https://pubs.usgs. gov/tm/1a1/.

Davis, B.E., 2005, A guide to the proper selection and use of federally approved sediment and water-quality samplers: U.S. Geological Survey Open-File Report 2005-1087, 20 p.

DeSimone, L.A., and Howes, B.L., 1998, Nitrogen transport and transformations in a shallow aquifer receiving wastewater discharge: A mass balance approach: Water Resources Research, v. 34, p. 271-285.

Desmarais, K., and Rojstaczer, S., 2002, Inferring source waters from measurements of carbonate spring responses to storms: Journal of Hydrology, v. 260, p. 118-134.

Dubrovsky, N.M., Burow, K.R., Clark, G.M., Gronberg, J.M., Hamilton P.A., Hitt, K.J., Mueller, D.K., Munn, M.D., Nolan, B.T., Puckett, L.J., Rupert, M.G., Short, T.M., Spahr, N.E., Sprague, L.A., and Wilber, W.G., 2010, The quality of our Nation's waters-Nutrients in the Nation's streams and groundwater, 1992-2004: U.S. Geological Survey Circular 1350, $174 \mathrm{p}$.

Edwards Aquifer Authority, 2015, Edwards Aquifer Authority hydrologic data report for 2015-Groundwater: Accessed February 13, 2018, at https://www.edwardsaquifer. org/science-and-maps/research-and-scientific-reports/ hydrologic-data-reports.

Edwards Aquifer Authority, 2017a, The Edwards aquiferScientific research and data-About the Edwards aquifer: Accessed May 2017 at https://www.edwardsaquifer.org/ science-and-maps/about-the-edwards-aquifer.

Edwards Aquifer Authority, 2017b, The Edwards aquiferScientific research and data-Aquifer levels: Accessed May 2017 at https://www.edwardsaquifer.org/science-and-maps/ aquifer-data/data-downloads.

Fahlquist, Lynne, and Ardis, A.F., 2004, Quality of water in the Trinity and Edwards aquifers, south-central Texas, 1996-98: U.S. Geological Survey Scientific Investigations Report 2004-5201, 17 p. 
Fairchild, I.J., Borsato, A., Tooth, A.F., Frisia, S., Hawkesworth, C.J., Huang, Y., McDermott, F., and Spiro, B., 2000, Controls on trace element (Sr-Mg) compositions of carbonate cave waters-Implications for speleothem climatic records: Chemical Geology, v. 166, p. 255-269.

Fishman, M.J., ed., 1993, Methods of analysis by the U.S. Geological Survey National Water Quality LaboratoryDetermination of inorganic and organic constituents in water and fluvial sediments: U.S. Geological Survey OpenFile Report 93-125, $217 \mathrm{p}$.

Fishman, M.J., and Friedman, L.C., 1989, Methods for determination of inorganic substances in water and fluvial sediments: U.S. Geological Survey Techniques of WaterResources Investigations, book 5, chap. A1, 545 p.

Fritz, Peter, and Fontes, J.C., eds., 1980, Handbook of environmental isotope geochemistry, v. 1-The terrestrial environment: Amsterdam, Elsevier, 545 p.

Gat, J.R., 1981, Groundwater, in Gat, J.R., and Gonfiantini, R., eds., Stable isotope hydrology-Deuterium and oxygen-18 in the water cycle: Vienna, Austria, International Atomic Energy Agency, p. 223-240.

Gilliom, R.J., Barbash, J.E., Crawford, C.G., Hamilton, P.A., Martin, J.D., Nakagaki, N., Nowell, L.H., Scott, J.C., Stackelberg, P.E., Thelin, G.P., and Wolock, D.M., 2006, Pesticides in the Nation's streams and ground water, 1992-2001: U.S. Geological Survey Circular 1291, 172 p.

Greater Edwards Aquifer Alliance, 2014, Unique resource: Accessed October 13, 2017, at http://www.aquiferalliance. net/unique-resource/.

Griffiths, J.F., and Strauss, R.F., 1985, The variety of Texas weather: Weatherwise, v. 38, p. 137-141.

Hamilton, J.M., Johnson, S., Mireles, J., Esquilin, R., Burgoon, C., Luevano, G., Gregory, D., Gloyd, R., Sterzenback, J., Mendoza, R., and Schindel, G.M., 2008, Edwards Aquifer Authority hydrogeologic data report for 2007: Edwards Aquifer Authority Report 08-02, $229 \mathrm{p}$.

Heaton, T.H.E., 1986, Isotopic studies of nitrogen pollution in the hydrosphere and atmosphere: A review: Chemical Geology, v. 59, p. 87-102.

Hem, J.D., 1985, Study and interpretation of the chemical characteristics of natural water ( $3 \mathrm{~d}$ ed.): U.S. Geological Survey Water-Supply Paper 2254, 263 p., accessed April 24, 2017, at http://pubs.usgs.gov/wsp/wsp2254/.

Homer, C.G., Huang, C., Yang, L., Wylie, B.K., and Coan, M.J., 2001, National Land Cover Database 2001 (NLCD 2001): Sioux Falls, S. Dak., U.S. Geological Survey, EROS Data Center, MRLC Project, accessed October 2007 at http://seamless.usgs.gov/.
Hübner, H., 1986, Isotope effects of nitrogen in soil and the biosphere, in Fritz, P., and Fontes, J.C., eds., Handbook of environmental isotope geochemistry, v. 2b, The terrestrial environment: Elsevier, p. 361-425.

Hüskes, R., and Levsen, K., 1997, Pesticides in rain: Chemosphere, v. 35, no. 12, p. 3013-3024.

Jones, B.D., 1991, Texas-Floods and droughts, in Paulson, R.W., Chase, E.B., Roberts, R.S., and Moody, D.W., comps., National water summary 1988-89-Hydrologic events and floods and droughts: U.S. Geological Survey Water-Supply Paper 2375, p. 513-520.

Jones, I.C., Banner, J.L., and Humphrey, J.D., 2000, Estimating recharge in a tropical karst aquifer: Water Resources Research, v. 36, p. 1289-1299.

Katz, B.G., Chelette, A.R., and Pratt, T.R., 2004, Use of chemical and isotopic tracers to assess nitrate contamination and ground-water age, Woodville Karst Plain, USA: Journal of Hydrology 289, p. 36-61.

Kendall, C., 1998, Tracing nitrogen sources and cycling in catchments, chap. 16 of Kendall, Carol, and McDonnell, J.J., eds., Isotope tracers in catchment hydrology: Amsterdam, Elsevier, p. 519-576.

Kendall, C., and McDonnell, J.J., eds., 1998, Isotope tracers in catchment hydrology: Amsterdam, The Netherlands, Elsevier Science, 839 p.

Kendall, C., Doctor, D.H., and Young, M.B., 2014, Environmental isotope applications in hydrologic studies, in Holland, H.D., and Turekian, K.K., eds., Treatise on geochemistry (2d ed.), v. 7, p. 273-327.

Kendall, C., Elliott, E.M., and Wankel, S.D., 2007, Tracing anthropogenic inputs of nitrogen to ecosystems, chap. 12 of Michener, R.H., and Lajtha, K., eds., Stable isotopes in ecology and environmental science ( $2 \mathrm{~d}$ ed.): Oxford, Blackwell Publishing, p. 375-449, accessed February 13, 2018, at https://doi.org/10.1002/9780470691854.ch12.

Kennedy, E.J., 1983, Computation of continuous records of streamflow: U.S. Geological Survey Techniques of Water-Resources Investigations, book 3, chap. A13, 53 p., accessed August 3, 2015, at http://pubs.usgs.gov/twri/ twri3-a13/.

Kennedy, E.J., 1984, Discharge ratings at gaging stations: U.S. Geological Survey Techniques of Water-Resources Investigations, book 3, chap. A10, 59 p. [Also available at https://pubs.usgs.gov/twri/twri3-a10/.] 
Klemt, W.B., Knowles, T.R., Edler, G.R., and Sieh, T.W., 1979, Ground-water resources and model applications for the Edwards (Balcones fault zone) aquifer in the San Antonio region: Texas Water Development Board Report $239,88 \mathrm{p}$.

Koepnick, R.B., Burke, W.H., Denison, R.E., Hetherington, E.A., Nelson, H.F., Otto, J.B., and Waite, L.E., 1985, Construction of the seawater ${ }^{87} \mathrm{Sr} /{ }^{86} \mathrm{Sr}$ curve for the Cenozoic and Cretaceous-Supporting data: Chemical Geology (Isotope Geoscience Section), v. 58, p. 55-81.

Lajtha, K., and Jones, J., 2013, Trends in cation, nitrogen, sulfate and hydrogen ion concentrations in precipitation in the United States and Europe from 1978 to 2010: A new look at an old problem: Biogeochemistry, v. 116, p. 303334.

Lakey, B., and Krothe, N.C., 1996, Stable isotopic variation of storm discharge from a perennial karst spring: Water Resources Research, v. 32, p. 721-731.

Lambert, R.B., Opsahl, S.P., and Musgrove, MaryLynn, 2017, Water quality, sources of nitrate, and chemical loadings in the Geronimo Creek and Plum Creek watersheds, southcentral Texas, April 2015-March 2016: U.S. Geological Survey Scientific Investigations Report 2017-5121, 49 p., accessed February 1, 2018, at https://doi.org/10.3133/ $\operatorname{sir} 20175121$.

Lawrence, J.R., 1998, Isotopic spikes from tropical cyclones in surface waters - Opportunities in hydrology and paleoclimatology: Chemical Geology, v. 144, p. 153-160.

Lawrence, J.R., and Gedzelman, S.D., 1996, Low stable isotope ratios of tropical cyclone rains: Geophysical Research Letters, v. 23, p. 527-530.

Lindgren, R.J., Dutton, A.R., Hovorka, S.D., Worthington, S.R.H., and Painter, S., 2004, Conceptualization and simulation of the Edwards aquifer, San Antonio region, Texas: U.S. Geological Survey Scientific Investigations Report 2004-5277, 143 p.

Lindgren, R.J., 2006, Diffuse-flow conceptualization and simulation of the Edwards aquifer, San Antonio region, Texas: U.S. Geological Survey Scientific Investigations Report 2006-5319, 48 p.

Lohmann, K.C., 1988, Geochemical patterns of meteoric diagenetic systems and their application to studies of paleokarst, in James, N.P., and Choquette, P.W., eds., Paleokarst: New York, Springer-Verlag, p. 58-80.

Lucey, K.J., and Goolsby, D.A., 1993, Effects of climatic variations over 11 years on nitrate-nitrogen concentrations in the Raccoon River, Iowa: Journal of Environmental Quality, v. 22, p. 38-46.
Maclay, R.W., and Land, L.F., 1988, Simulation of flow in the Edwards aquifer, San Antonio region, Texas, and refinements of storage and flow concepts: U.S. Geological Survey Water-Supply Paper 2336-A, 48 p.

Maclay, R.W., and Small, T.A., 1983, Hydrostratigraphic subdivisions and fault barriers of the Edwards aquifer, south-central Texas, U.S.A.: Journal of Hydrology, v. 61, p. 127-146.

Mahler, B.J., Garner, B.D., Musgrove, M., Guilfoyle, A.L., and Rao, M.V., 2006, Recent (2003-05) water quality of Barton Springs, Austin, Texas, with emphasis on factors affecting variability: U.S. Geological Survey Scientific Investigations Report 2006-5299, 83 p., 5 appendixes.

Mahler, B.J., Musgrove, M., Herrington, C., and Sample, T.L., 2011a, Recent (2008-10) concentrations and isotopic compositions of nitrate and concentrations of wastewater compounds in the Barton Springs zone, south-central Texas, and their potential relation to urban development in the contributing zone: U.S. Geological Survey Scientific Investigations Report 2011-5018, 39 p.

Mahler, B.J., Musgrove, M., Sample, T.L., and Wong, C.I., 2011b, Recent (2008-10) water quality in the Barton Springs segment of the Edwards aquifer and its contributing zone, central Texas, with emphasis on factors affecting nutrients and bacteria: U.S. Geological Survey Scientific Investigations Report 2011-5139, 66 p.

Maloszewski, P., Stichler, W., Zuber, A., and Rank, D., 2002, Identifying the flow systems in a karstic-fissuredporous aquifer, the Schneealpe, Austria, by modeling of environmental ${ }^{18} \mathrm{O}$ and ${ }^{3} \mathrm{H}$ isotopes: Journal of Hydrology, v. 256 , p. $48-59$.

Martin, J.D., Stone, W.W., Wydoski, D.S., and Sandstrom, M.W., 2009, Adjustment of pesticide concentrations for temporal changes in analytical recovery, 1992-2006: U.S. Geological Survey Scientific Investigations Report 20095189, 23 p. plus appendixes.

Menne, M.J., Durre, Imke, Vose, R.S., Gleason, B.E., and Houston, T.G., 2012, An overview of the Global Historical Climatology Network-Daily database: Journal of Atmospheric and Oceanic Technology, v. 29, no. 7, p. 897910, accessed September 2, 2017, at https://doi.org/10.1175/ JTECH-D-11-00103.1.

Miller, S.M., Sweet, C.W., Depinto, J.V., and Hornbuckle, K.C., 2000, Atrazine and nutrients in precipitation: Results from the Lake Michigan mass balance study: Environmental Science and Technology, v. 34, p. 55-61. 
Moore, P.J., Martin, J.B., and Screaton, E.J., 2009, Geochemical and statistical evidence of recharge, mixing, and controls on spring discharge in an eogenetic karst aquifer: Journal of Hydrology, v. 376, nos. 3-4, p. 443-455, accessed February 12, 2018, at https://doi.org/10.1016/j. jhydrol.2009.07.052.

Mueller, D.K., Schertz, T.L., Martin, J.D., and Sandstrom, M.W., 2015, Design, analysis, and interpretation of field quality-control data for water-sampling projects: U.S. Geological Survey Techniques and Methods, book 4, chap. C4, 54 p., accessed September 30, 2017, at https:// dx.doi.org/10.3133/tm4C4.

Musgrove, M., and Banner, J.L., 2004, Controls on the spatial and temporal variability of vadose dripwater geochemistry-Edwards aquifer, central Texas: Geochimica et Cosmochimica Acta, v. 68, p. 1007-1020.

Musgrove, M., Fahlquist, L., Houston, N.A., Lindgren, R.J., and Ging, P.B., 2010, Geochemical evolution processes and water-quality observations based on results of the National Water-Quality Assessment Program in the San Antonio segment of the Edwards aquifer, 1996-2006: U.S. Geological Survey Scientific Investigations Report 20105129, $93 \mathrm{p}$.

Musgrove, M., Fahlquist, L., Stanton, G.P., Houston, N.A., and Lindgren, R.J., 2011, Hydrogeology, chemical characteristics, and water sources and pathways in the zone of contribution of a public-supply well in San Antonio, Texas: U.S. Geological Survey Scientific Investigations Report 2011-5146, $194 \mathrm{p}$.

Musgrove, M., and Crow, C.L., 2012, Origin and characteristics of discharge at San Marcos Springs based on hydrologic and geochemical data (2008-10), Bexar, Comal, and Hays Counties, Texas: U.S. Geological Survey Scientific Investigations Report 2012-5126, 94 p.

Musgrove, M., Opsahl, S.P., Mahler, B.J., Herrington, C., Sample, T.L., and Banta, J.R., 2016, Source, variability, and transformation of nitrate in a regional karst aquifer: Edwards aquifer, central Texas: Science of the Total Environment, v. 568, p. 457-469.

National Oceanic and Atmospheric Administration, 2017a, National Centers for Environmental Information: Global Historical Climatology Network (GHCN): Accessed August 2015 at https://www.ncdc.noaa.gov/data-access/landbased-station-data/land-based-datasets/global-historicalclimatology-network-ghen.

National Oceanic and Atmospheric Administration, 2017b, National Weather Service: Advanced Hydrologic Prediction Service: Accessed September 2017 at http://water.weather. gov/precip/.
National Oceanic and Atmospheric Administration, 2017c, National Centers for Environmental Information, climate monitoring, Climate at a Glance, Palmer Drought Severity Index for Texas Climate Division 6, Edwards Plateau: Accessed July 2017 at https://www.ncdc.noaa.gov/cag/.

National Oceanic and Atmospheric Administration, 2017d, National Centers for Environmental Information, Climate Data Online, daily summaries, San Antonio International Airport, San Antonio, Texas, cooperative station identifier 417945: Accessed March 2017 at https://www.ncdc.noaa. gov/cdo-web/.

Nations, B.K., and Hallberg, G.R., 1992, Pesticides in Iowa precipitation: Journal of Environmental Quality, v. 21, p. $486-492$.

Ockerman, D.J., 2005, Simulation of streamflow and estimation of recharge to the Edwards aquifer in the Hondo Creek, Verde Creek, and San Geronimo Creek watersheds, south-central Texas, 1951-2003: U.S. Geological Survey Scientific Investigations Report 2005-5252, 37 p.

Oetting, G.C., Banner, J.L., and Sharp, J.M., Jr., 1996, Geochemical evolution of saline groundwaters in the Edwards aquifer, central Texas-Regional stratigraphic, tectonic, and hydrodynamic controls: Journal of Hydrology, v. 181, p. $251-283$.

Opsahl, S.P., 2012, Quality of surface-water runoff in selected streams in the San Antonio segment of the Edwards aquifer recharge zone, Bexar County, Texas, 1997-2012: U.S. Geological Survey Data Series 740, 20 p., 2 appendixes.

Opsahl, S.P., Musgrove, M., and Slattery, R.N., 2017, New insights into nitrate dynamics in a karst system gained from high-frequency optical sensor measurements: Journal of Hydrology, v. 546, p. 179-188.

Opsahl, S.P., Lambert, R.B., Mahler, B.J., and Musgrove, M., 2018, Water-quality data characterizing the San Antonio segment of the Edwards aquifer with an emphasis on processes influencing nutrient and pesticide concentrations and factors affecting aquifer vulnerability, 2010-2016: U.S. Geological Survey data release, https://doi.org/10.5066/ F7KP81C5.

Oren, O., Yechieli, Y., Böhlke, J.K., and Dody, A., 2004, Contamination of groundwater under cultivated fields in an arid environment, Central Arava Valley, Israel: Journal of Hydrology, v. 290, p. 312-328.

Patton, C.J., and Kryskalla, J.R., 2003, Methods of analysis by the U.S. Geological Survey National Water Quality Laboratory-Evaluation of alkaline persulfate digestion as an alternative to Kjeldahl digestion for determination of total and dissolved nitrogen and phosphorus in water: U.S. Geological Survey Water-Resources Investigations Report 03-4174, $33 \mathrm{p}$. 
Patton, C.J., and Kryskalla, J.R., 2011, Colorimetric determination of nitrate plus nitrite in water by enzymatic reduction, automated discrete analyzer methods: U.S. Geological Survey Techniques and Methods, book 5, chap. B8.

Patton, C.J., and Truitt, E.P., 2000, Methods of analysis by the U.S. Geological Survey National Water Quality Laboratory-Determination of ammonium plus organic nitrogen by a Kjeldahl digestion method and an automated photometric finish that includes digest cleanup by gas diffusion: U.S. Geological Survey Open-File Report 00-170, $31 \mathrm{p}$.

Pape, J.R., Banner, J.L., Mack, L.E., Musgrove, M., and Guilfoyle, A., 2010, Controls on oxygen isotope variability in precipitation and cave drip waters, central Texas, USA: Journal of Hydrology, v. 385, p. 203-215.

Pellerin, B.A., Bergamaschi, B.A., Downing, B.D., Saraceno, J.F., Garrett, J.A., and Olsen, L.D., 2013, Optical techniques for the determination of nitrate in environmental waters: Guidelines for instrument selection, operation, deployment, maintenance, quality assurance, and data reporting: U.S. Geological Survey Techniques and Methods 1-D5, 37 p.

Plummer, L.N., 1977, Defining reactions and mass transfer in part of the Floridan aquifer: Water Resources Research, v. 13, p. $801-812$.

Potter, T.L., and Coffin, A.W., 2017, Assessing pesticide wet deposition risk within a small agricultural watershed in the Southeastern Coastal Plain (USA): Science of the Total Environment, v. 580, p. 158-167.

Puente, Celso, 1978, Method of estimating natural recharge to the Edwards aquifer in the San Antonio area, Texas: U.S. Geological Survey Water-Resources Investigations Report 78-10, $34 \mathrm{p}$.

Rabalais, N.N., Turner, R.E., and Wiseman, W.J., 2002, Gulf of Mexico hypoxia, A.K.A. "The dead zone": Annual Review of Ecology and Systematics, v. 33, p. 235-263.

Rantz, S.E., and others, 1982a, Measurement and computation of streamflow: Volume 1. Measurement of stage and discharge: U.S. Geological Survey Water-Supply Paper $2175,284 \mathrm{p}$.

Rantz, S.E., and others, 1982b, Measurement and computation of streamflow: Volume 2. Computation of discharge: U.S. Geological Survey Water-Supply Paper 2175, 631 p.

Révész, Kinga, and Coplen, T.B., 2008a, Determination of the $\delta\left({ }^{2} \mathrm{H} /{ }^{1} \mathrm{H}\right)$ of water-RSIL lab code 1574 , chap. C1 of Révész, Kinga, and Coplen, T.B., eds., Methods of the Reston Stable Isotope Laboratory: U.S. Geological Survey Techniques and Methods 10-C1, 27 p. [Also available at http://pubs.er.usgs.gov/publication/tm10C1.]
Révész, Kinga, and Coplen, T.B., 2008b, Determination of the $\delta\left({ }^{18} \mathrm{O} /{ }^{16} \mathrm{O}\right)$ of water-RSIL lab code 489, chap. C2 of Révész, Kinga, and Coplen, T.B., eds., Methods of the Reston Stable Isotope Laboratory: U.S. Geological Survey Techniques and Methods, 10-C2, 28 p. [Also available at http://pubs.usgs.gov/tm/2007/tm10c2.]

Reynolds, B., and Edwards, A., 1995, Factors influencing dissolved nitrogen concentrations and loadings in upland streams of UK: Agricultural Water Management, v. 27, p. 181-202.

Rounds, S.A., 2006, Alkalinity and acid neutralizing capacity (ver. 3.0): U.S. Geological Survey Techniques of WaterResources Investigations, book 9, chap. A6, section 6.6, accessed December 12, 2017, at http://pubs.water.usgs.gov/ twri9A6/.

Rusjan, S., Brilly, M., and Mikos, M., 2008, Flushing of nitrate from a forested watershed: An insight into hydrological nitrate mobilization mechanisms through seasonal high-frequency stream nitrate dynamics: Journal of Hydrology, v. 354, p. 187-202.

Sandstrom, M.W., Stroppel, M.E., Foreman, W.T., and Schroeder, M.P., 2001, Methods of analysis by the U.S. Geological Survey National Water Quality LaboratoryDetermination of moderate-use pesticides and selected degradates in water by $\mathrm{C}-18$ solid-phase extraction and gas chromatography/mass spectrometry: U.S. Geological Survey Water-Resources Investigations Report 01-4098, $70 \mathrm{p}$.

Sauer, V.B., and Turnipseed, D.P., 2010, Stage measurements at gaging stations: U.S. Geological Survey Techniques and Methods, book 3, chap. A7, 45 p.

Schultz, A.L., 1994, 1994 review and update of the position of the Edwards aquifer freshwater/saline-water interface from Uvalde to Kyle, Texas: Edwards Underground Water District Report 94-05, 31 p.

Scribner, E.A., Thurman, E.M., Goolsby, D.A., Meyer, M.T., Battaglin, W.A., and Kolpin, D.W., 2005, Summary of significant results from studies of triazine herbicides and their degradation products in surface water, ground water, and precipitation in the Midwestern United States during the 1990s: U.S. Geological Survey Scientific Investigations Report 2005-5094, 27 p.

Sea-Bird Scientific, 2018, SUNA V2 UV nitrate sensor: Accessed April 11, 2018, at http:/www.seabird.com/suna.

Sharp, J.M., Jr., and Banner, J.L., 1997, The Edwards aquifer-A resource in conflict: Geological Society of America (GSA) Today, v. 7, p. 1-9. 
Struzeski, T.M., DeGiacomo, W.J., and Zayhowski, E.J., 1996, Methods of analysis by the U.S. Geological Survey National Water Quality Laboratory-Determination of dissolved aluminum and boron in water by inductively coupled plasma-atomic emission spectrometry: U.S. Geological Survey Open-File Report 96-149, 17 p. [Also available at https://pubs.er.usgs.gov/publication/ofr96149.]

Teledyne Isco, 2018, 3700 full-size portable sampler: Accessed April 11, 2018, at http://www.teledyneisco.com/ en-uk/water-and-wastewater/3700-sampler.

Thorkildsen, D.F., and McElhaney, P.D., 1992, Model refinement and applications for the Edwards (Balcones fault zone) aquifer in the San Antonio region, Texas: Texas Water Development Board Report 340, 33 p.

Thurman, E.M., and Cromwell, A.E., 2000, Atmospheric transport, deposition, and fate of triazine herbicides and their metabolites in pristine areas at Isle Royale National Park: Environmental Science \& Technology, v. 34, no. 15, p. 3079-3085.

Thurman, E.M., and Fallon, J.D., 1996, The deethylatrazine to atrazine ratio as an indicator of the onset of the spring flush of herbicides into surface water of the Midwestern United States: International Journal of Environmental Analytical Chemistry, v. 65, p. 203-214.

Townsend, M.A., and Young, D.P., 2000, Atrazine and its metabolites as indicators of stream-aquifer interaction in Kansas, USA: International Journal of Environmental Analytical Chemistry, v. 78, no. 1, p. 9-23.

Tremallo, R.L., Johnson, S., Hamilton, J.M., Winterle, J., Eason, S., and Hernandez, J.C., 2015, Edwards Aquifer Authority hydrologic data report for 2014: San Antonio, Tex., Edwards Aquifer Authority, 79 p., accessed September 1, 2017, at https://www.edwardsaquifer. org/science-and-maps/research-and-scientific-reports/ hydrologic-data-reports.

Trudgill, S.T., Laidlaw, I.M.S., and Smart, P.L., 1980, Soil water residence times and solute uptake on a dolomite bedrock-Preliminary results: Earth Surface Processes, v. 5, p. 91-100.

Turnipseed, D.P., and Sauer, V.B., 2010, Discharge measurements at gaging stations: U.S. Geological Survey Techniques and Methods, book 3, chap. A8, 87 p.

U.S. Census Bureau, 2017, QuickFacts: San Antonio city, Texas: Accessed August 2017 at https://www.census.gov/ quickfacts/fact/table/sanantoniocitytexas/LND110210.
U.S. Environmental Protection Agency, 1998, R.E.D. facts: DCPA: Accessed November 1, 2017, at https://archive.epa. gov/pesticides/reregistration/web/pdf/0270fact.pdf.

U.S. Environmental Protection Agency, 2017a, Sole source aquifers for drinking water: Accessed October 1, 2017, at https://www.epa.gov/dwssa.

U.S. Environmental Protection Agency, 2017b, Ground water and drinking water: National Primary Drinking Water Regulations: Accessed September 2017 at https://www.epa. gov/ground-water-and-drinking-water/national-primarydrinking-water-regulations.

U.S. Geological Survey, variously dated, National field manual for the collection of water-quality data: U.S. Geological Survey Techniques of Water-Resources Investigations, book 9, chaps. A1-A10, accessed January 1, 2014, at http:// pubs.water.usgs.gov/twri9A.

U.S. Geological Survey, 2017, National Water Information System: Accessed September 29, 2017, at http://dx.doi. org/10.5066/F7P55KJN.

Van Metre, P.C., Alvarez, D.A., Mahler, B.J., Nowell, L., Sandstrom, M., and Moran, P., 2016, Complex mixtures of pesticides in Midwest U.S. streams indicated by POCIS time-integrating samplers: Environmental Pollution, v. 220, pt. A, p. 431-440.

Van Pul, W.A.J., Bidleman, T.F., Brorström-Lundén, E., Builtjes, P.J.H., Dutchak, S., Duyzer, J.H., Gryning, S.-E., Jones, K.C., Van Dijk, H.F.G., and Van Jaarsveld, J.H.A., 1999, Atmospheric transport and deposition of pesticides: An assessment of current knowledge, in Van Dijk, H.F.G., Van Pul, W.A.J., and De Voogt, P., eds., Fate of pesticides in the atmosphere: Implications for environmental risk assessment: Proceedings of a workshop organised by The Health Council of the Netherlands, held in Driebergen, The Netherlands, April 22-24, 1998: Dordrecht, Springer Netherlands, p. 245-256.

Vogel, J.R., Majewski, M.S., and Capel, P.D., 2008, Pesticides in rain in four agricultural watersheds in the United States: Journal of Environmental Quality, v. 37, p. 1101-1115.

Wagner, R.J., Boulger, R.W., Jr., Oblinger, C.J., and Smith, B.A., 2006, Guidelines and standard procedures for continuous water-quality monitors - Station operation, record computation, and data reporting: U.S. Geological Survey Techniques and Methods 1-D3, 51 p. plus 8 attachments, accessed April 10, 2006, at http://pubs.water. usgs.gov/tm1d3. 
Wells, E.R., and Krothe, N.C., 1989, Seasonal fluctuation in ${ }^{15} \mathrm{~N}$ of groundwater nitrate in a mantled karst aquifer due to marcopore transport of fertilizer-derived nitrate: Journal of Hydrology, v. 112, p. 191-201.

White, W.B., 1988, Geomorphology and hydrology of karst terrains: New York, Oxford University Press, 464 p.

White, W.B., 2002, Karst hydrology—Recent developments and open questions: Engineering Geology, v. 65, p. 85-105.

Wilde, F.D., ed., variously dated, Field measurements: U.S. Geological Survey Techniques of Water-Resources Investigations, book 9, chap. A6, accessed June 1, 2014, at http://pubs.water.usgs.gov/twri9A6/.

Zaugg, S.D., Sandstrom, M.W., Smith, S.G., and Fehlberg, K.M., 1995, Methods of analysis by the U.S. Geological Survey National Water Quality Laboratory-Determination of pesticides in water by $\mathrm{C}-18$ solid-phase extraction and capillary-column gas chromatography/mass spectrometry with selected-ion monitoring: U.S. Geological Survey Open-File Report 95-181, 60 p. 
For more information about this publication, contact

Director, Texas Water Science Center

U.S. Geological Survey

1505 Ferguson Lane

Austin, TX 78754-4501

For additional information visit http://tx.usgs.gov/.

Publishing support provided by Lafayette Publishing Service Center 


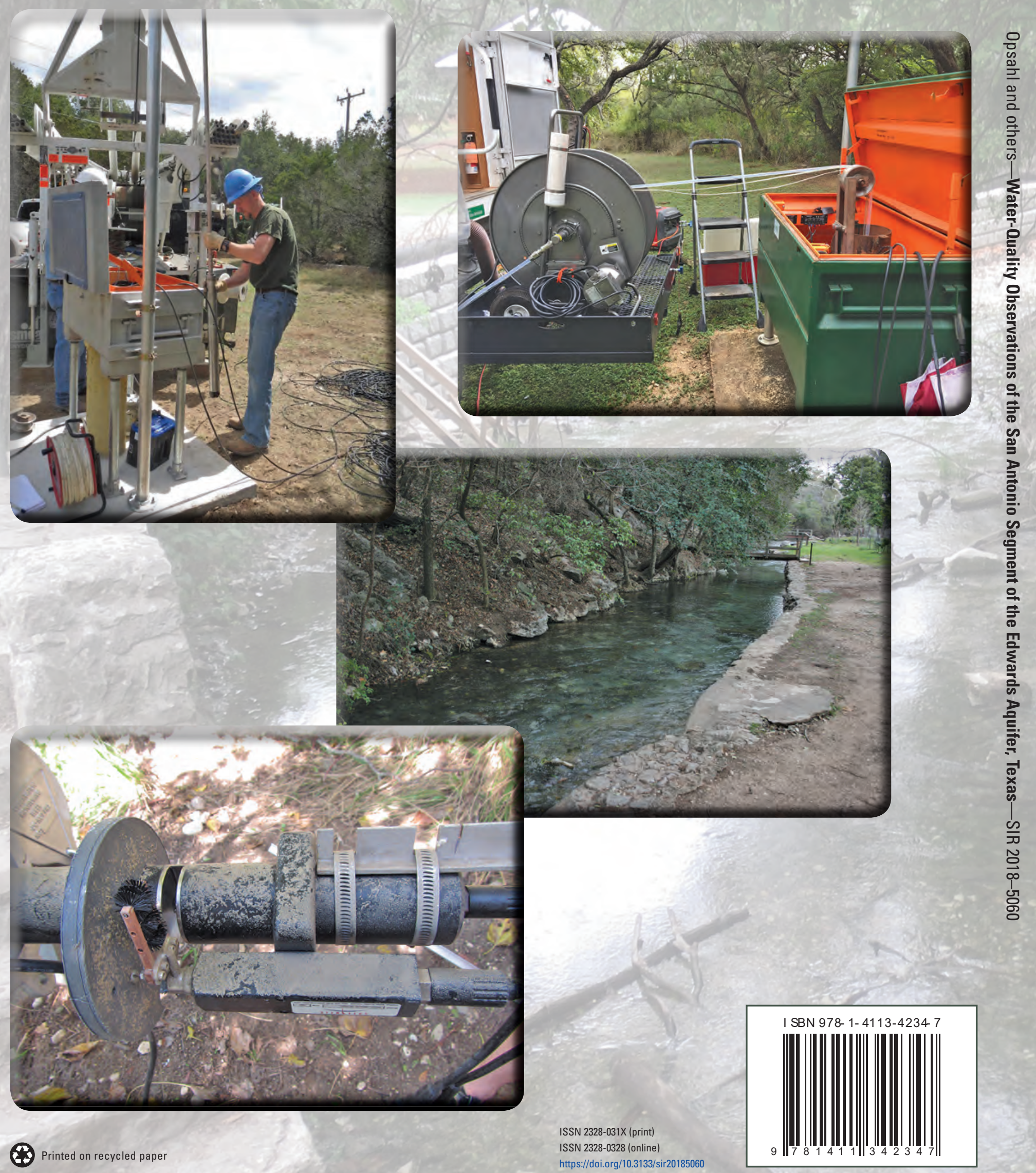

